\title{
Water in the Hindu Kush Himalaya
}

\section{Coordinating Lead Authors}

Christopher A. Scott, University of Arizona, USA. e-mail: cascott@email.arizona.edu Fan Zhang, Institute of Tibetan Plateau Research, Chinese Academy of Sciences, China. e-mail: zhangfan@itpcas.ac.cn

Aditi Mukherji, International Centre for Integrated Mountain Development, Nepal. e-mail: aditi.mukherji@icimod.org; aditidebroy@gmail.com (corresponding author)

\section{Lead Authors}

Walter Immerzeel, Utrecht University, The Netherlands. e-mail: w.w.immerzeel@uu.nl Daanish Mustafa, King's College London, London, UK. e-mail: daanish.mustafa@kcl.ac.uk Luna Bharati, International Water Management Institute, Nepal. e-mail: 1.bharati@cgiar.org

\section{Contributing Authors}

Hongbo Zhang, Institute of Tibetan Plateau Research, Chinese Academy of Sciences, China. e-mail: zhanghongbo@itpcas.ac.cn

Tamee Albrecht, University of Arizona, USA. e-mail: talbrecht@email.arizona.edu Arthur Lutz, Utrecht University, The Netherlands. e-mail: a.lutz@futurewater.nl Santosh Nepal, International Centre for Integrated Mountain Development, Nepal. e-mail: santosh.nepal@icimod.org

Afreen Siddiqi, Massachusetts Institute of Technology, USA. e-mail: siddiqi@mit.edu Harris Kuemmerle, Kings College, London, UK. e-mail: harris.kuemmerle@kcl.ac.uk Manzoor Qadir, United Nations University - Institute for Water, Environment \& Health, Canada. e-mail: Manzoor.Qadir@unu.edu

Sanjeev Bhuchar, International Centre for Integrated Mountain Development, Nepal. e-mail: sanjeev.bhuchar@icimod.org

Anjal Prakash, International Centre for Integrated Mountain Development, Nepal. e-mail: anjal.prakash@icimod.org

Rajiv Sinha, Indian Institute of Technology, Kanpur, India. e-mail: rsinha@iitk.ac.in

\section{Review Editors}

Jayanta Bandyopadhyay, Observer Research Foundation, India. e-mail: jayanta@iimcal.ac.in Cecilia Tortajada, National University of Singapore, Singapore. e-mail: cecilia.tortajada@nus.edu.sg

\section{Corresponding Author}

Aditi Mukherji, International Centre for Integrated Mountain Development, Nepal. e-mail: aditi.mukherji@icimod.org; aditidebroy@gmail.com 


\section{Contents}

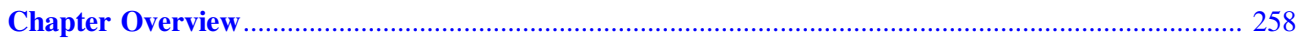

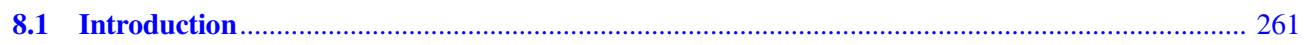

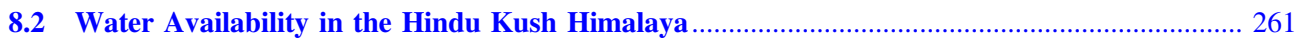

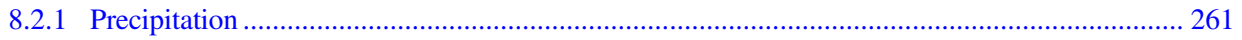

8.2.2 Cryospheric Contributions to River Flows ……................................................................ 262

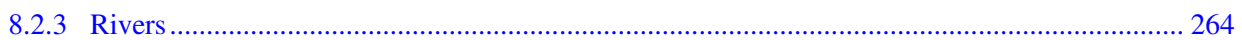

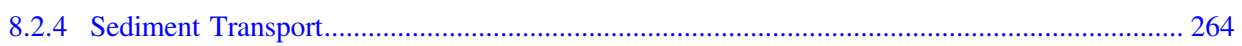

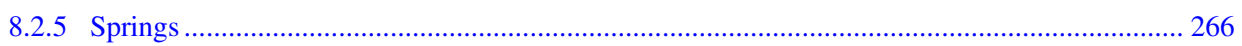

8.2.6 Groundwater in Lowland Areas of HKH Basins ................................................................. 267

8.2.7 Implications of Climate Change on HKH Water Resources.................................................. 267

8.3 Water Use in the Hindu Kush Himalaya ......................................................................... 269

8.3.1 Agricultural Water Use in the Mountains, Hills, and Plains of HKH River Basins................ 271

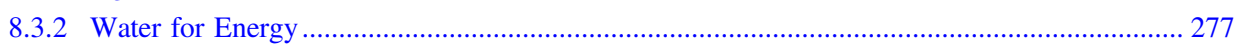

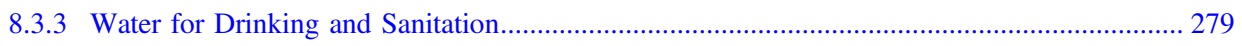

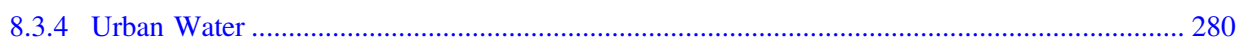

8.3.5 Water Quality: Major Biological and Chemical Contaminants Linked to Urbanisation........... 282

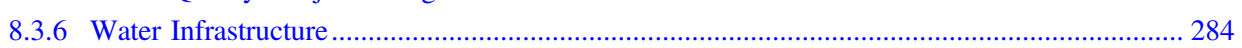

8.3.7 Ecosystem Processes and Environmental Flows .................................................................... 285

8.4 Water Governance in the Hindu Kush Himalaya ..................................................................... 285

8.4.1 Characterization of Existing Water Governance Institutions ................................................ 286

8.4.2 River-Basin Approaches and Transboundary Conflict and Cooperation .................................. 288

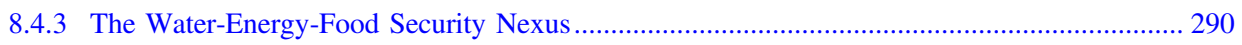

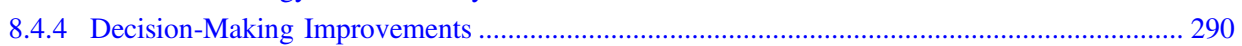

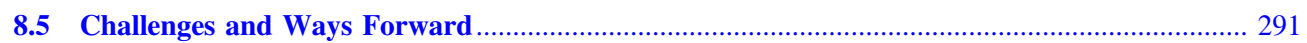

References

\section{Chapter Overview}

\section{Key Findings}

1. The Hindu Kush Himalaya (HKH) mountains provide two billion people a vital regional lifeline via water for food (especially irrigation), water for energy (hydropower), and water for ecosystem services (riparian habitats, environmental flows, and rich and diverse cultural values).

2. Glacier and snow melt are important components of streamflow in the region; their relative contribution increases with altitude and proximity to glacier and snow reserves. Groundwater, from springs in the mid-hills of the HKH, is also an important contributor to river baseflow, but the extent of groundwater contribution to river flow is not known due to limited scientific studies.
3. Water governance in the HKH is characterised by hybrid formal-informal regimes with a prevalence of informal institutions at the local level and formal state institutions at national and regional levels. Synergy and support between state and informal water-management institutions is often lacking. Gender inequity is prevalent in both formal and informal institutions and translates into inequity in access to water.

\section{Policy Messages}

1. To counter the formidable and immediate threats to water security posed by human drivers including climate change, equitable, productive, and 
sustainable water use should be promoted through decentralised decision making, effective management of urban pollution, improved infrastructure planning, and enhanced regional cooperation.

2. Ensuring regional and local water security requires proactive HKH-wide cooperation, specifically in open data sharing among scientists and ministry or agency personnel; conflict management via regional platforms; and investment of publicand private-sector funds for generating and exchanging knowledge, enhancing public awareness, and stimulating action.

3. Tradeoffs between upstream and downstream water uses; between rural and urban areas; and among irrigation, energy, industrial and other sectors must be carefully managed in order to enhance water security, meet the Sustainable Development Goals, and ensure water availability for hydropower that will be essential for $\mathrm{HKH}$ countries to achieve (intended) Nationally Determined Contributions for emissions mitigation as established in the 2015 Paris climate accord. This requires balancing evidence-based policy with political imperatives at the local, national, and HKH regional scales, while ensuring that mountain communities derive commensurate benefits from $\mathrm{HKH}$ water resources in a manner that safeguards downstream water needs.

Commonly described as the "water tower for Asia," the Hindu Kush Himalaya (HKH) plays an important role in ensuring water, food, energy, and environmental security for much of the continent. The HKH is the source of ten major rivers that provide water-while also supporting food and energy production and a range of other ecosystem services - for two billion people across Asia. This chapter takes stock of current scientific knowledge on the availability of water resources in the $\mathrm{HKH}$; the varied components of its water supply; the impact of climate change on future water availability; the components of water demand; and the policy, institutions, and governance challenges for water security in the region.

The monsoon provides the main source of water for the eastern Himalaya; much of this comes as rain between June and September. In winter, the western Himalaya receives at least half of its precipitation from western disturbances (well-established).

Knowledge of the amount and distribution of precipitation at higher altitudes (above $5000 \mathrm{~m}$ above mean sea level, masl) in the HKH is poor. There are very few meteorological stations at these altitudes and those that exist may not consistently provide data. The lack of reliable data has led to significant anomalies in observed rain and snow data and in observed glacier mass balances. More stations at higher altitudes are urgently needed (well-established).

While glacier and snow melt are important components of overall streamflow in the region, their significance varies widely - ranging from very high in western rivers, such as the Indus, to low in eastern rivers, such as the Ganges and the Brahmaputra. In the eastern rivers, rainfall runoff contributes the largest share of streamflow. Still, this share varies substantially within each river basin. The relative contribution of glacier and snow melt, as opposed to rainfall runoff, increases with altitude and proximity to glacier and snow reserves (well-established).

Groundwater, from springs in the mid-hills of the HKH, is an important contributor to river baseflow, but the exact extent of this contribution is not known due to limited scientific studies and evidence. The role and contribution of springs to overall water budgets in the region is poorly understood (wellestablished). We urgently need better scientific knowledge of groundwater in the $\mathrm{HKH}$ - especially because millions of mountain people depend directly on springs. More is known about groundwater endowments in the plains. Groundwater is overexploited in the western plains, while it remains largely untapped in the eastern plains (well-established).

Climate change is expected to drive consistent increases in the total streamflow of the Indus, Ganges, and Brahmaputra rivers. In the Indus, this increase will come for a limited period from increased glacial melt, while in the Ganges and the Brahmaputra, it is expected to come mainly from precipitation (established but incomplete). Beyond the mid-century, the Indus Basin may experience decreases in pre-monsoon flow resulting from decreasing glacial melt (inconclusive). Changes in future flow volumes will also have a seasonal dimension, with increased peak runoff and decreased low flow in some sub-basins (established, but incomplete). Pre-monsoon flows are expected to decline, with implications for irrigation, hydropower, and ecosystem services (unresolved).

Disaggregated water-use data are not available for the region defined as the $\mathrm{HKH}$. However, across the entire territory of all eight countries sharing the $\mathrm{HKH}$, about one-fifth of available renewable water resources are being used for human purposes. Countries vary widely in their water-resource endowments and withdrawals (established, but incomplete).

For all eight countries-Afghanistan, Bangladesh, Bhutan, China, India, Myanmar, Nepal, and Pakistan-that comprise the region, agriculture (HKH and geographical regions outside $\mathrm{HKH}$ ) accounts for the largest share of water use-accounting for over $90 \%$ of use in Afghanistan and $65 \%$ in more industrialised China (well-established). India, Bangladesh, Pakistan, and China together account for more 
than $50 \%$ of world's groundwater withdrawals (well-established). These withdrawals mostly take place in the plains of river basins that originate in the HKH. Groundwater is used mostly for irrigation and in other sectors like urban water provisioning (well-established).

The HKH includes three sub-regions of agricultural water use each with distinct implications in terms of water management: high mountains, mid-hills, and plains. Agriculture in the high mountains and the mid-hills tends to be largely rainfed with supplemental irrigation in the mid-hills. Agriculture in the plains is mostly irrigated (well-established). The nature and dynamics of the region's agriculture are shifting in response to climate and demographic changes.

Another use of water-hydropower-is mostly non-consumptive. Yet hydropower can change the timing and location of river flow thereby disrupting natural flow regimes, which can harm other water users, such as local irrigation, capture fisheries and ecosystems (established). Such conflicts especially arise in the mid-hills and the mountains - which mark the location of most current and foreseeable hydropower sites. Very often, mountain people do not derive commensurate benefits from these projects (well-established). Appropriate benefit-sharing norms are needed to ensure that mountain people also benefit from the region's vast hydropower potential (established, but incomplete).

Burgeoning cities and small towns in the HKH confront severe water stress from urbanization, which is often unplanned (well-established). This water stress often leads to concerns over water quality, but it also gives rise to practices such as the reuse of partially treated wastewater for agriculture (established, but incomplete).

In response to the Millennium Development Goals, the HKH made remarkable strides in achieving access to safe drinking water. The region is also committed to meeting the Sustainable Development Goals (SDGs). Still, much work remains to be done to provide basic sanitation (well-established). Rather than managing water for health and sanitation in isolation from water for irrigation, hydropower, municipal supply, and ecosystems, it would be more effective to integrate water management for multiple uses.

The important role of HKH rivers in providing ecosystem services is not well appreciated. Present law and policy frameworks are not adequate to ensure that infrastructure development does not impinge on ecosystem services (established, but incomplete).

To ensure water security in the HKH, adequate water availability alone is not enough - what is needed is good water governance. Such governance must be politically and culturally tailored to the local, national, and regional contexts (well-established). Water governance in the $\mathrm{HKH}$ is characterised by hybrid formal-informal regimes with a prevalence of informal institutions at the local level and formal state institutions at national and regional levels; often with lack of synergy and support between state and informal water-management institutions. Gender inequity is prevalent in both formal and informal institutions. Urban water-supply challenges posed by formal institutional regimes often forced upon pre-existing informal institutions have deleterious consequences for water quality and quantity. Transboundary institutions for water resources are inadequate or non-existent, heightening the risk of conflict while also offering opportunities for HKH-wide cooperation (wellestablished).

Challenges and opportunities vary at different levels: micro (watershed and springshed); meso (river basin); and macro (regional). Among the leading causes of poor water governance in the $\mathrm{HKH}$ are constantly changing conditions in the ecologically fragile sloping landscape, dispersed settlements, unequal power dynamics, centralised decision making, inadequate opportunities for local communities to influence their water-security decisions, despite the presence of local institutions (well-established). Throughout the $\mathrm{HKH}$, more attention needs to be paid to HKH-specific conditions as well as more general challenges including participatory and cooperative decision making (formal, informal, and hybrid), evidence-based policies, transparent program implementation, accountability at all levels, and transboundary and regional cooperation.

\section{Water Security and the Sustainable Develop- ment Goals}

SDG Goal 6 is entirely focused on water. While drinking water and sanitation rightly remain central to SDG 6, other considerations have gained importance as well: water quality, wastewater management and reuse, transboundary cooperation, ecosystem services, capacity building, and cooperation.

The SDG-consistent priorities and specific targets for the HKH region (with our assessment comments in italics) include the following:

Ensure a year-round secure water supply in the mountains with universal and affordable access to safe drinking water, sanitation, and water for productive purposes.

- Create secure water supply for key development sectors (agriculture, energy) that are viable year-round. Meeting this target will require that socio-economic and environmental impacts be comprehensively assessed with adequate and timely compensation for mountain communities who are impacted.

- Build effective and efficient mechanisms to implement and monitor transboundary cooperation 
agreements. Document and assess existing transboundary cooperation agreements in order to apply lessons and expand the scope of future agreements.

- Achieve universal and equitable access to safe and affordable drinking water for all mountain people by 2030. As a priority target for mountain communities, this will require that comprehensive programs for spring revival and improvement be taken up, and in urban areas, additional sources of secure and affordable water be made available.

- Achieve access to adequate and equitable sanitation services and hygiene education for all in mountain regions. Community-based models with attention to women and marginalized sections of the community must be taken up with support from local and national governments.

- Reduce the water collecting time and work load of women and children (and of aging males, whenever relevant) by 2030. Comprehensive programs for spring revival and improvement are urgently required to reduce the burden of water access by all members of mountain communities.

- Support and strengthen the participation of mountain communities in water management. Increase decision-making power of local governments and ensure the incorporation of local-knowledge systems and local institutions in water management.

\subsection{Introduction}

Water security has emerged as a subset of human securityone that has been raising serious concern throughout the early part of the 21st century. For the purposes of the HIMAP assessment, we use a definition of water security adapted from UN-Water (2013) and Scott et al. (2013) as follows: Water security is the capacity of $H K H$ populations to safeguard sustainable access to adequate quantities of acceptable quality water for resilient societies and ecosystems, to ensure protection against water-borne pollution and water-related disasters, and to adapt to uncertain global change-in a regional climate of peace and political stability.

This chapter focuses on current and future water endowments and their spatial distribution (Sect. 8.2), use (Sect. 8.3), and governance (Sect. 8.4). Water quality is recognized to be crucial for human health and ecosystem processes, but the relative lack of observed data and modeled dynamics makes it difficult to systematically address water quality. The chapter focuses primarily on the question of water quantity. Nonetheless, issues related to quality-such as, sediment in large river systems, challenges of wastewater management in HKH urban systems, and major biological and chemical contaminants linked to urbanization - are also discussed.

The major river basins originating in the region are shown in Fig. 8.1. Throughout the chapter, we use specific terms to refer to nested geographical scales: micro (local, springshed, community); meso (river basin, subnational to national); macro (HKH-regional, transboundary); and global (beyond HKH, global).

\subsection{Water Availability in the Hindu Kush Himalaya}

This section attempts to assess the principal sources of water in the HKH, including precipitation, glacial melt, snowmelt, runoff, river discharge, springs, and groundwater. As already noted, water quantity is the principal focus. Aggregate water availability together with water use data are included in Sect. 8.3. Temporal dynamics are specifically referred to in the section on climate change impacts.

\subsubsection{Precipitation}

In general, the climate in the eastern part of the Himalayas is characterized by the East Asian and Indian monsoon systems, causing the bulk of precipitation to occur from June to September. The precipitation intensity shows a strong north-south gradient caused by orographic effects (Galewsky 2009). Precipitation patterns in the Pamir, Hindu Kush, and Karakoram ranges in the west are also characterized by westerly and southwesterly flows, causing precipitation to be more evenly distributed throughout the year, as compared with the eastern parts (Bookhagen and Burbank 2010). In the Karakoram, as much as two-thirds of the annual high-altitude precipitation occurs during the winter months (Hewitt 2011). About half of this winter precipitation is brought about by western disturbances, which are eastward propagating cyclones that bring sudden winter precipitation to the northwestern parts of the Indian subcontinent (Barlow et al. 2005).

Meteorological stations are relatively sparse in the $\mathrm{HKH}$ (Shea et al. 2015b), in large part due to the poor accessibility of the terrain. Precipitation is especially variable over short horizontal distances due to orographic effects; however, high-altitude precipitation gauge networks are very rare. If there are rain gauges, they are mostly located in the river valleys where precipitation amounts are smaller than at 


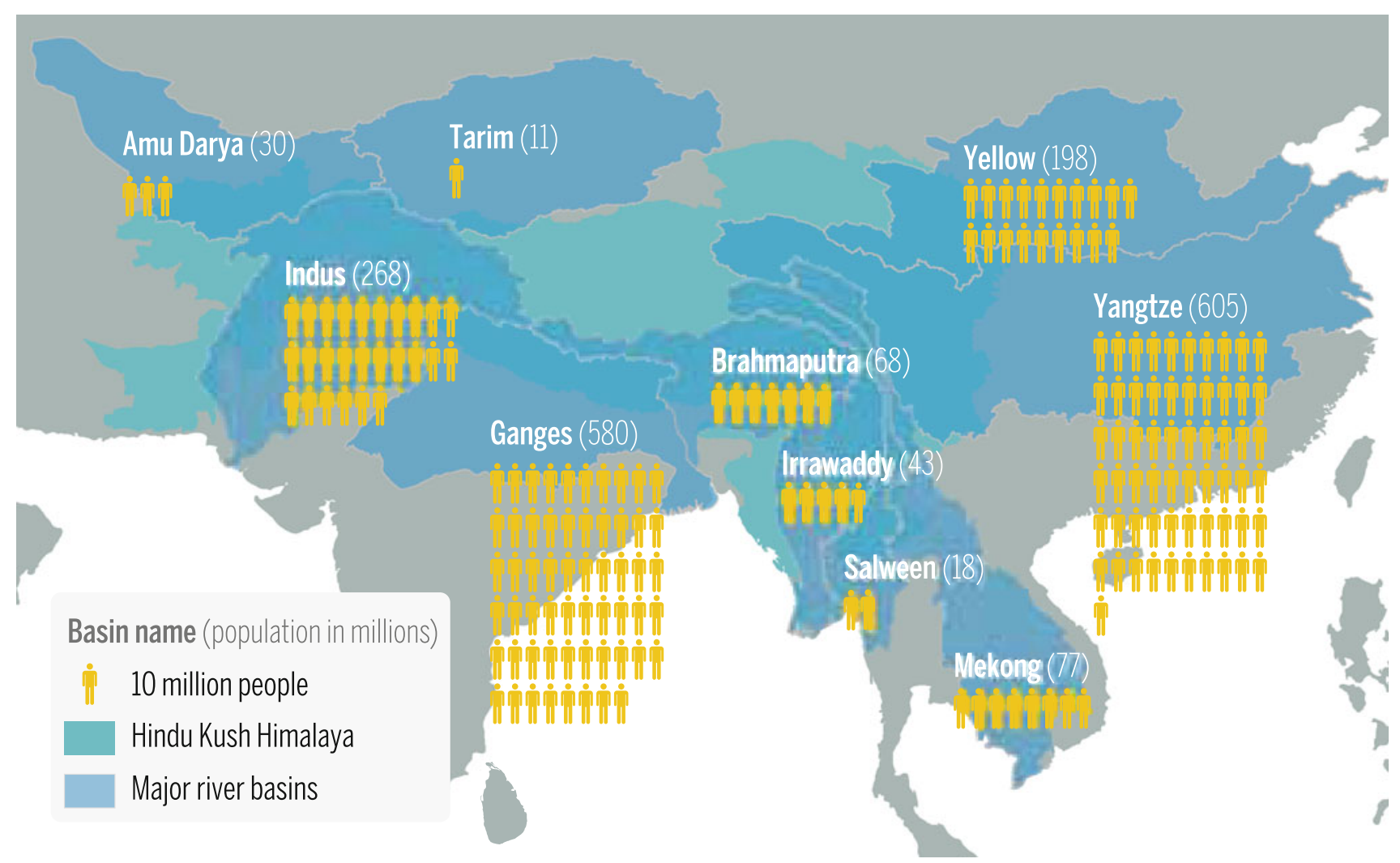

Fig. 8.1 Major river basins originating in the Hindu Kush Himalaya (Data source Box 1.1; Table 1.2)

higher altitudes. Furthermore, most gauges have difficulty accurately capturing snowfall. Direct snow-accumulation measurements-using snow pillows, pits, and cores from accumulation zones-are also scarce and usually only account for short periods of time. Therefore, HKH precipitation predictions based on ground observations are not very accurate. In order to obtain more accurate predictions, observed data must be replaced by or supplemented with data gathered through other approaches, including remote sensing and reanalysis techniques to aid in generating gridded climate datasets. Recent research for the upper Indus basin indicates that in order for precipitation data to correspond with observed glacier mass balances and river discharges, the actual amount of precipitation would have to be double the amount estimated from station data (Immerzeel et al. 2015; Dahri et al. 2016).

\subsubsection{Cryospheric Contributions to River Flows}

At the river-basin scale, in the eastern HKH basins, glaciers play a relatively small role in annual surface runoff. Nevertheless, recent work shows that within each basin there is significant variability (Fig. 8.2); the closer one gets to the glaciers and snow reserves within a basin, the greater the relative importance of glacier and snowmelt runoff (Lutz et al. 2014). Several large-scale benchmark studies have focused on quantifying the importance of glacier and snowmelt runoffs in the overall hydrology of large Asian river basins. Permafrost contributions are addressed in Chap. 5. Glaciers have the potential to provide seasonally delayed meltwater to the rivers. Meltwater can make the greatest contribution to river flow during warm and dry seasons, which is particularly important to the water budget in water-scarce lowlands that are densely populated.

A global study estimating seasonally delayed glacier runoff relative to precipitation input showed that the Indus basin had the greatest human dependence on glacier water within the HKH (Kaser et al. 2010). In another benchmark study, the Normalized Melt Index (NMI) was used to quantify the importance of both glacier and snow meltwater for five major river basins in Asia (the Indus, Ganges, Brahmaputra, Yangtze, and Yellow). The NMI is defined as the volumetric glacier and snowmelt in a basin divided by its downstream natural discharge. This study revealed very large differences among the basins, ranging from $46 \%$ snow and $32 \%$ glacier contributions in the Indus to $6 \%$ snow and $3 \%$ glacier contributions in the Ganges, which is largely dependent on the summer monsoon (Immerzeel et al. 2010). 


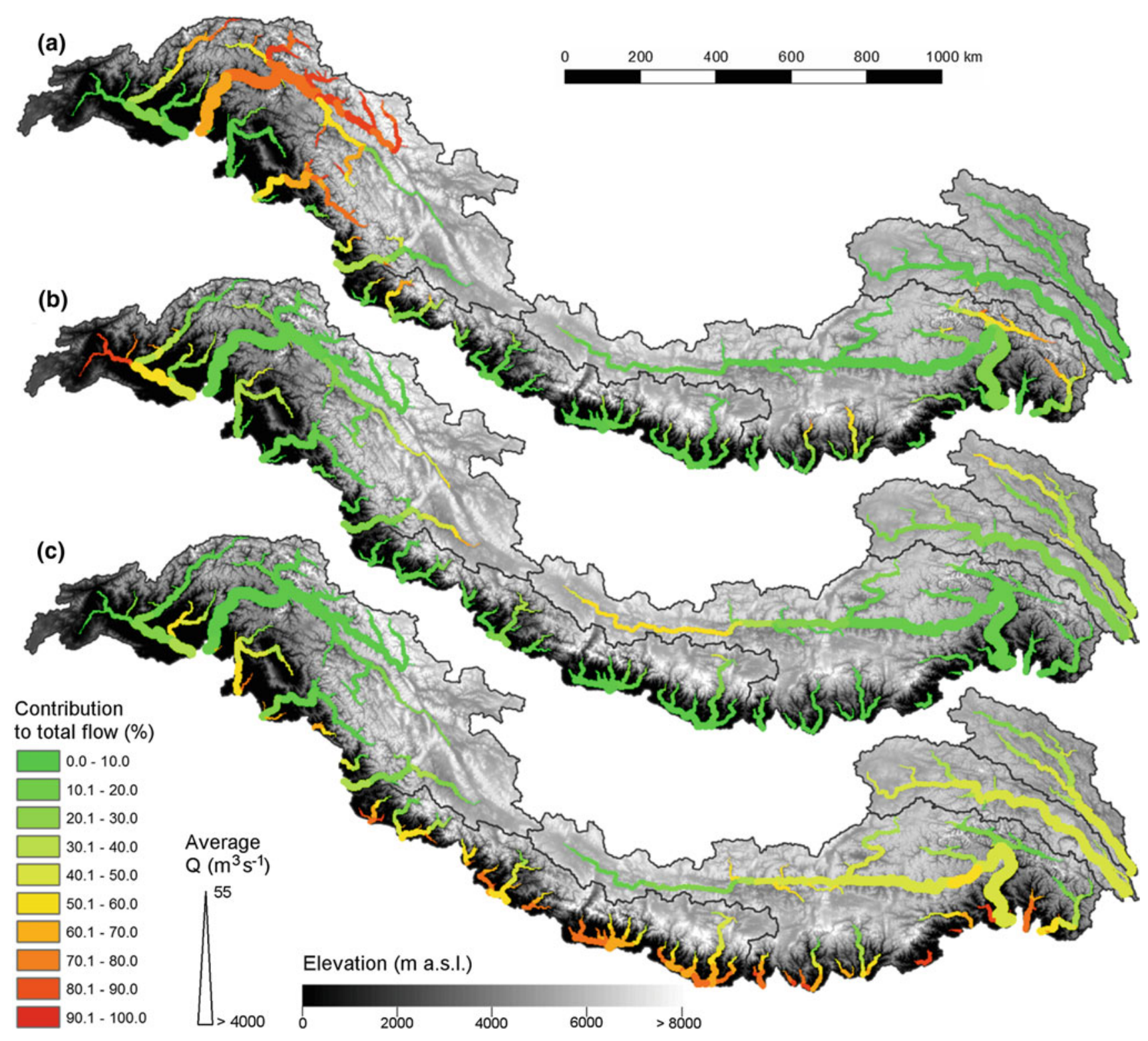

Fig. 8.2 Contribution to total flow by (a) glacial melt, (b) snowmelt, and (c) rainfall-runoff for major streams during the reference period of 1998-2007. Line thickness indicates the average discharge during the reference period (Source Reprinted from "Consistent increase in High

Asia's runoff due to increasing glacier melt and precipitation" by Lutz, A. F. et al., 2014, Nature Climate Change, 4, p. 590. Copyright (C) 2014 by Nature Publishing Group)

Another study assessed the upper limit of glacier melt contribution to streamflow to estimate the potential melt contribution by combining energy balance computationthat calculated the amount of energy available for melt - with the Global Land Ice Measurements from Space (GLIMS) database (Schaner et al. 2012). The results once again highlighted the Indus and small basins close to glacier outlets as the most dependent on glacier melt. Yet another study used the Variable Infiltration Capacity (VIC) model to assess the Yellow, Yangtze, Mekong, Salween, Brahmaputra, and Indus rivers. Results showed that these rivers - except for the
Indus - were primarily dependent on rainfall runoff. By contrast, the total glacier melt and snowmelt contribution to the Indus streamflow was about $80 \%$ (Zhang et al. 2013).

In the headwaters close to the glacier and snow source areas, smaller-scale studies based on either stable isotope analysis (Racoviteanu et al. 2013) or modeling (Immerzeel et al. 2013; Nepal et al. 2014b; Ragettli et al. 2015; Shrestha et al. 2015b; Tahir et al. 2015) showed the significant dependence of river flow on both glacier and snowmelt, even if the larger basins in which the headwaters are located have minimal dependence on meltwater. 


\subsubsection{Rivers}

As indicated in Fig. 8.1, the HKH functions as the water tower (Immerzeel et al. 2010) for much of the southern and eastern Asian continent, serving as the source for ten major river systems. Variations are very pronounced in river discharge, the contributions of different sources, and temporal trends (both seasonal and inter-annual).

A number of studies analyzing observed records have attempted to attribute trends in discharge to meteorological trends:

- A study analyzing streamflow trends from nineteen stations in the upper Indus basin indicated that in highly glaciated catchments the discharge is best correlated to temperature (Archer 2003). According to the analysis, the volume of summer discharge in middle-altitude catchments is predominantly governed by the preceding winter's precipitation, whereas streamflow in catchments further downstream is mainly determined by winter and monsoon rainfall.

- Another study of the upper Indus basin (Khattak et al. 2011) found that increasing trends in streamflow could be related to increases in mean and maximum temperature, particularly in the winter and spring seasons.

- Sharif et al. (2013) concluded that highly glaciated catchments in the upper Indus basin showed decreasing trends in streamflow, whereas streamflow had increased in less glaciated catchments. The study showed flow decreasing in early summer but increasing in the winter.

- Mukhopadhyay and Khan (2014b) showed that runoff in the central Karakoram increased during the melting season from 1985 to 2010. They concluded that increased flow was possible under neutral glacier mass balance conditions as a result of increased temperature and precipitation. This allowed the rate of mass cycling of the glacier to increase even as the mass balance remained neutral.

- Bashir et al. (2017) found an overall decreasing trend in annual accumulated discharge in the Indus river at Tarbela Dam. According to their study, the annual increase in precipitation and decrease in runoff suggested an overall increase in storage of water in the elevated regions of the watershed, mainly in the form of snow and glaciated ice.

A limited number of published studies have estimated the composition of streamflow within different catchments or sub-basins of the Indus, Ganges, and Brahmaputra (Table 8.1). Results are, however, difficult to compare due to the variation in concepts, approaches, and application scales employed.

The findings of each study were largely dependent on the availability of data and application scale (for example, the size of the catchment or basin included in the simulation). The estimates by Immerzeel et al. (2011, 2013), for instance, were made using a distributed model, including a simple ice flow model, whereas the estimates by Soncini et al. (2015) were made using a semi-distributed cryospheric-hydrological model fed and validated with in situ measurements.

River discharge is an essential component of the regional water balance, with important contributions from glacial melt, snowmelt, and spring flow within the HKH. Additionally, river flows play a dominant role in sediment transport and groundwater recharge in the plains. Spatial and temporal trends in river flows are addressed in Sect. 8.2.7.

\subsubsection{Sediment Transport}

There is a strong relationship between upstream erosion, mass wasting, in-stream transport, and downstream sediment deposition in the HKH. Erosion in the region is strongly determined by young and fragile geological formations, land-management practices, and monsoon precipitation (Nepal et al. 2014a). High sediment flux in the rivers within this region may be largely attributed to the young unconsolidated mountain system with frequent geologic activity that makes the landmass fragile and unstable, in addition to which the intense precipitation of the Indian summer monsoon on the southern side of the main Himalayan ridgeline and the East Asian summer monsoon on the eastern edge of the Tibetan Plateau also contribute a great deal (Bandyopadhyay 2017). Sediment load in rivers can be used as an important proxy for evaluating ecological and environmental conditions as well as the severity of regional erosion (Zeng et al. 2018). The location of villages, type of agricultural land use (including terracing, road access, and other features of the structure), and function of human settlements in the HKH have important mutual effects on erosion, sediment transport, and deposition. An important issue is the interrelation between sediment flux and downstream hazards, such as rapid and frequent channel migration and extensive flooding due to channel instability triggered by channel bed aggradation.

About one-third of the global sediment deposited to the oceans is estimated to be generated from the Tibetan Plateau and its neighbouring regions (Milliman and Meade 1983). The high sedimentation of rivers within this region may be largely attributed to the young, unconsolidated mountain system with more frequent geological activities that make the landmass fragile and unstable as well as the precipitation patterns of the Indian monsoon and the East Asian summer monsoon that fall more intensely on the south side of the main Himalayan ridgeline and the eastern edge of the Tibetan Plateau respectively (Bandyopadhyay 2017). The 
Table 8.1 Results of studies estimating streamflow composition at selected locations

\begin{tabular}{|c|c|c|c|c|c|c|c|c|}
\hline \multirow{2}{*}{$\begin{array}{l}\text { Site } \\
\text { (river/location) }\end{array}$} & \multirow[t]{2}{*}{ Country, major river } & \multirow[t]{2}{*}{ Reference } & \multirow{2}{*}{$\begin{array}{l}\text { Basin area } \\
\left(\mathrm{km}^{2}\right)\end{array}$} & \multirow[t]{2}{*}{ Period } & \multicolumn{4}{|c|}{ Contribution by component (\%) } \\
\hline & & & & & $\begin{array}{l}\text { Glacier } \\
\text { melt }\end{array}$ & Snowmelt & $\begin{array}{l}\text { Rain } \\
\text { runoff }\end{array}$ & Base-flow \\
\hline \multirow{2}{*}{$\begin{array}{l}\text { Satluj, Bhakra } \\
\text { Dam }\end{array}$} & \multirow[t]{2}{*}{ India, Indus River } & Singh and Jain (2002) & 56,874 & 1986-1996 & \multicolumn{2}{|l|}{59} & 41 & - \\
\hline & & Lutz et al. (2014) & - & $1998-2007$ & 27.6 & 20.8 & 38.6 & 13 \\
\hline \multirow{5}{*}{$\begin{array}{l}\text { Langtang Khola, } \\
\text { Kyangjing }\end{array}$} & \multirow[t]{5}{*}{ Nepal, Ganges River } & Immerzeel et al. (2011) & 360 & $2001-2010$ & 47 & 6.9 & 28.8 & 17.4 \\
\hline & & Immerzeel et al. (2013) & - & $1961-1990$ & 13 & 20.4 & 10 & 56.6 \\
\hline & & $\begin{array}{l}\text { Racoviteanu et al. } \\
\text { (2013) }\end{array}$ & 352.3 & 1988-2006 & 58.3 & \multicolumn{3}{|l|}{41.7} \\
\hline & & Ragettli et al. (2015) & 350 & $2012-2013$ & 26 & 40 & 34 & - \\
\hline & & Lutz et al. (2014) & - & 1998-2007 & 52.5 & 12.8 & 25 & 9.7 \\
\hline \multirow[t]{3}{*}{$\begin{array}{l}\text { Dudh Koshi, } \\
\text { Rabuwa Bazar }\end{array}$} & Nepal, Ganges River & $\begin{array}{l}\text { Racoviteanu et al. } \\
\text { (2013) }\end{array}$ & $3,711.4$ & 1988-2006 & 7.4 & \multicolumn{3}{|l|}{92.6} \\
\hline & & Lutz et al. (2014) & - & 1998-2007 & 18.8 & 4.8 & 64.8 & 11.6 \\
\hline & & Nepal et al. (2014b) & 3,712 & 1985-1997 & 17 & 17 & 46 & 20 \\
\hline Lhasa Basin & $\begin{array}{l}\text { China, Yarlung } \\
\text { Tsangpo River }\end{array}$ & Prasch et al. (2013) & 26,339 & $1971-2000$ & 3 & 41 & 56 & - \\
\hline \multirow[t]{3}{*}{$\begin{array}{l}\text { Indus, Besham } \\
\text { Qila }\end{array}$} & \multirow[t]{3}{*}{$\begin{array}{l}\text { Pakistan, Indus } \\
\text { River }\end{array}$} & $\begin{array}{l}\text { Mukhopadhyay and } \\
\text { Khan (2014a) }\end{array}$ & 164,867 & 1969-2010 & 21 & 49 & \multicolumn{2}{|l|}{30} \\
\hline & & Lutz et al. (2014) & - & $1998-2007$ & 67.3 & 17.6 & 7.1 & 8 \\
\hline & & $\begin{array}{l}\text { Mukhopadhyay and } \\
\text { Khan (2015) }\end{array}$ & - & 1969-2010 & 25.8 & 44.1 & - & 30.2 \\
\hline \multirow[t]{4}{*}{$\begin{array}{l}\text { Hunza, Dainyor } \\
\text { Bridge }\end{array}$} & \multirow[t]{4}{*}{$\begin{array}{l}\text { Pakistan, Indus } \\
\text { River }\end{array}$} & $\begin{array}{l}\text { Mukhopadhyay and } \\
\text { Khan (2014a) }\end{array}$ & 13,732 & $1966-2010$ & \multicolumn{2}{|l|}{74} & \multicolumn{2}{|l|}{26} \\
\hline & & Lutz et al. (2014) & - & 1998-2007 & 80.6 & 9.6 & 1.3 & 8.5 \\
\hline & & $\begin{array}{l}\text { Mukhopadhyay and } \\
\text { Khan (2015) }\end{array}$ & 13,734 & $1966-2010$ & 42.8 & 31.3 & - & 25.9 \\
\hline & & Shrestha et al. (2015b) & 13,733 & $2002-2004$ & 33 & 50 & 17 & - \\
\hline Baltoro, Baltoro & $\begin{array}{l}\text { Pakistan, Indus } \\
\text { River }\end{array}$ & Immerzeel et al. (2013) & - & $1961-1990$ & 38.7 & 21.6 & 3.5 & 36.2 \\
\hline Shigar, Shigar & $\begin{array}{l}\text { Pakistan, Indus } \\
\text { River }\end{array}$ & Soncini et al. (2015) & $\sim 7,000$ & $1985-1997$ & 32.9 & 39.5 & 27.6 & \\
\hline
\end{tabular}

“_” indicates not available

Ganges-Brahmaputra River is one of the most sediment-laden rivers in the world, with annual sediment loads of 1235-1670 million tons (Milliman and Meade 1983; Abbas and Subramanian 1984). Approximately, half of this is deposited within the lower basin while the other half is delivered to the ocean (Islam et al. 1999). The annual sediment load of the Ganges River accounts for nearly two-thirds of the total sediment load in the Ganges-Brahmaputra (Abbas and Subramanian 1984). By contrast, the gross sediment load output from the upstream Yarlung Tsangpo River in Tibet is estimated to be just a small fraction $(<10 \%)$ of the total load in the Ganges-Brahmaputra River (Wasson 2003; Blöthe and Korup 2013), which is due to a large volume of coarse gravel and sand deposited in the upstream river valley (Wang et al. 2016). A recent study on the midstream
Yarlung Tsangpo River also indicates that the sediment yield in the catchment is much lower than other major rivers originating from plateaus, such as the upper Yellow River, the upper Yangtze River, the upper Indus River, and the Mekong River (Shi et al. 2018). The sediment load of the Koshi River (the easternmost tributary of the Ganges) is reported to be about 120 million tons per year at Chatra. Because of the high sediment load and the low gradient in the Indo-Gangetic Plain, the river's channel has shifted westward by about $115 \mathrm{~km}$ over the past 220 years (Gole and Chitale 1966; Dixit 2009; Chakraborty et al. 2010).

One of the most recent avulsions of the Koshi in 2008 was triggered by a breach in the embankment at Kusaha (12 km upstream of the Koshi barrage), resulting in an approximately $120 \mathrm{~km}$ shift of the middle fan region (Sinha 2009). This unprecedented avulsion was primarily attributed 
to large-scale bed aggradation due to siltation, thereby pushing the river close to the avulsion threshold (Sinha et al. 2014). Recent work has provided an assessment of sediment flux in the Koshi basin in relation to sediment connectivity and the factors controlling the pathways of sediment delivery (Mishra et al. 2016). This assessment has helped characterize sediment dynamics in complex morphological settings and in a mixed environment.

Due to its high-alpine topography, intense meltwater supply, and the summer monsoon, the Indus River transports large volumes of sediment (Nag and Phartiyal 2015), particularly from its upper reaches in northern Pakistan (Meybeck 1976; Ali and Boer 2007; Ashraf et al. 2017). The Yangtze River is ranked globally as the fifth largest river in terms of runoff and the fourth largest in terms of sediment load (Yang et al. 2011). Studies have shown that the upper river basin is the main sediment source for the Yangtze River, while significant deposition occurs in the middle and lower reaches where the slope is gentler (Chen et al. 2001; Wang et al. 2007; Yang et al. 2007). The Yellow River was once the most sediment-laden river in the world, but its sediment concentrations have decreased by approximately $90 \%$ since the 1950 s due to human activity (e.g., reforestation and engineering measures) and regional climate change (Xu et al. 2004; Wang et al. 2016). Both high sedimentation (i.e., when too much can affect the river's course or result in flooding) and low sedimentation (i.e., when too little may destroy the rich delta ecosystems) present management challenges (Giosan et al. 2014). Thus, the beneficial aspects or risks of sedimentation are largely dependent on the bearing capacity and the degree of change (Wang et al. 2016).

\subsubsection{Springs}

Mountain springs play an important hydrological role in generating streamflow for non-glaciated catchments and in maintaining winter and dry-season flows across numerous HKH basins. Springs are the primary water source for rural households in the HKH. 80\% of rural households in Sikkim rely on springwater (Tambe et al. 2009). Springs also contribute to the baseflow of many rivers in the region. In the Indian Himalaya, $64 \%$ of irrigated areas are fed by springs (Rana and Gupta 2009).

Due to factors related to anthropogenic impacts (such as deforestation, grazing, exploitative land use resulting in soil erosion, etc.) and climate change (e.g., highly variable rainfall), springs fed during the monsoon by groundwater or underground aquifers are reported to be drying up and threatening whole ways of life for local communities in most parts of the mid-hills of the HKH (Vashisht and Bam 2013; Mukherji et al. 2016). Springs have been particularly affected by the depletion of shallow water table because of reduced infiltration due to crust formation and by increased intensity of rainfall. They are further impacted by rapid socio-economic growth, demographic changes, and infrastructural developments, such as dams and road building (Mahamuni and Kulkarni 2012; Vashisht and Bam 2013; Mukherji et al. 2016). Due to scarce observation data, the status of most springs in this region is still unknown. According to research, nearly $50 \%$ of perennial springs in the Indian Himalaya have dried up or become seasonal (Rana and Gupta 2009). Spring discharges have also significantly declined (Sharda 2005). A case study in the Gaula River Basin in the central HKH showed that, by the late 1980s, spring flow had decreased by at least $25 \%$ (Valdiya and Bartarya 1989). In Sikkim, in the eastern HKH, the decrease in spring discharge was found to be over $35 \%$ during the 2000s (Tambe et al. 2012). In one of the mid-hills districts of Nepal, as many as $30 \%$ of the springs have dried up in the last decade, likely the result of a combination of biophysical, technical, and socio-economic factors (Sharma et al. 2016).

To address the water crisis caused by these dried-up springs, springshed-management strategies and conservation measures should be developed by merging scientific and community knowledge. In doing so, it is important to better establish the relationship between precipitation, recharge, and spring discharge (Negi and Joshi 2004). The few studies published on this matter are based on small, scattered areas (Negi and Joshi 2004; Vashisht and Sharma 2007; Tambe et al. 2012; Tarafdar 2013; Sharma et al. 2016; Kumar and Sen 2017a, b; Paramanik 2017) and reported results show significant variations across the HKH. While spring-discharge variation appears to be consistent with rainfall in Sikkim in the east (Tambe et al. 2012) and Uttarakhand in the central-western Himalaya (Agarwal et al. 2012), it shows an inverse pattern with monthly rainfall in the western Himalayan springs of Kashmir (Negi et al. 2012). These trends suggest that, in addition to precipitation, other causal factors and localized impacts should also be investigated.

Recent studies indicate the importance of developing an improved understanding of the aquifers through which groundwater recharges springs (Jeelani 2008; Mahamuni and Kulkarni 2012). A case study in the western Himalaya shows that spring discharge during the rainy season is very high for Karst springs and much lower for alluvium (fluvio-lacustrine) and Karewa (glacio-fluvio-lacustrine) springs (Jeelani 2008).

The anthropogenic impacts on spring discharge-including those from changes in land use and soil erosionhave been discussed in some studies (Singh and Pande 1989; Valdiya and Bartarya 1989; Tiwari and Joshi 2014). With glacial retreat increasing in this region, the disappearance of 
small glaciers may be a factor in the drying up of springs (Fort 2015). A workable and realistic management plan for spring watersheds needs both hydrogeological and hydrological characterization of catchments as well as a reliable modeling approach (Kresic and Stevanovic 2009). Thus, additional field investigations of declining springs-along with further research, detailed geohydrology, and modeling studies of well-observed spring catchments - are needed in the HKH.

\subsubsection{Groundwater in Lowland Areas of HKH Basins}

Hydrogeological characteristics of aquifers remain unknown in most parts of the HKH. Across the region, a number of groundwater studies have been conducted by characterizing aquifer systems in northwestern India (Narula and Gosain 2013; Lapworth et al. 2015) and northeastern India (Michael and Voss 2009; Mahamuni and Kulkarni 2012). In Nepal, studies conducted in Kathmandu Valley provide insight into the geological formation of aquifers (Shrestha et al. 1999), their hydrogeological characteristics (Kc 2003), and their spatial distribution (Pandey and Kazama 2011). These studies constitute a valuable knowledge base for guidance in groundwater management (Pandey et al. 2012). Aquifer mapping and groundwater level information at regular intervals need to be made publicly available.

In South Asia, groundwater constitutes the water source for over $75 \%$ of irrigated areas (Shah et al. 2006). Through the use of wells, groundwater also provides drinking water for $85 \%$ of rural population in India (Livingston 2009). For the HKH lowlands, too, groundwater is an extremely important source of water. In the plains of South Asia, groundwater is one of the most exploited water resources, of which significant depletions have been observed in the Indus basin of Pakistan (Ashraf and Ahmad 2008), the Kathmandu Valley of Nepal (Dixit and Upadhya 2005; Pandey et al. 2010), as well as northwestern region of India (Rodell et al. 2009).

Groundwater from subsurface recharge and glacier and snow melt can serve as temporary storage for river discharge in the HKH. A model-based study of water budget showed that the contribution of groundwater is about six times higher than that of glacier and snow melt in the central Nepal Himalaya (Andermann et al. 2012). This study also found a significant time lag between rainfall and discharge, indicating the importance of groundwater as temporary subsurface storage for the HKH lowlands. Currently, only a limited number of model-based studies in the HKH (Andermann et al. 2012; Narula and Gosain 2013; Racoviteanu et al. 2013) adequately account for groundwater processes due to data scarcity.

\subsubsection{Implications of Climate Change on HKH Water Resources}

The implications of climate change on the availability of water resource - spatial distribution, temporal dynamics, and water security in general - are extremely significant. Climate change processes and future projections for the HKH are addressed in detail in Chap. 4 and projections of glacial change are addressed in Chap. 5.

Lutz et al. (2014) showed that, as a result of climate change, a consistent increase in streamflow is expected at large scales for the upstream reaches of the Indus, Ganges, and Brahmaputra rivers until at least 2050. For the upper Indus, this is mainly due to increased glacial melt, whereas for the Ganges and Brahmaputra, the projected increase in streamflow is driven primarily by increased precipitation. These streamflow projections, however, have a large degree of uncertainty, especially for the upper Indus, as projections for precipitation show contradicting patterns.

These studies also show the various responses to climate change among rivers with different streamflow patterns. For example, the Indus River flow is dominated by temperature-driven glacial melt during summer; therefore, the uncertainty in future flow is relatively minor due to the small uncertainty in future temperature changes. On the other hand, the Kabul River has much larger components of rainfall runoff and snowmelt, increasing the uncertainty in future flow due to the large uncertainty in future precipitation. The absolute amounts of glacial melt and snowmelt are not projected to change much in the Brahmaputra and the rivers in the Ganges basin, but their relative contributions are expected to decrease due to increased rainfall runoff. As a result, projections show increased peak discharge in the monsoon season with a large uncertainty in the magnitude of flow increases.

On a smaller scale, projections through the end of the century for the Langtang and the Baltoro catchments (Immerzeel et al. 2013) indicate a consistent increase in total streamflow for both, despite their contrasting climates (RCP4.5 and RCP8.5). These increases range from $172 \mathrm{~mm} /$ year (Langtang, 31\%) to $278 \mathrm{~mm} / \mathrm{year}$ (Baltoro, $46 \%$ ) in 2021-2050 for RCP 4.5 and from $493 \mathrm{~mm} /$ year (Langtang, 88\%) to $576 \mathrm{~mm} /$ year (Baltoro, 96\%) in 20712100 for RCP 8.5. In the Baltoro catchment, glacial melt is a larger component of total streamflow, and projected increases in melt are expected to be the main cause of the significant increase expected in total streamflow. In the Langtang catchment, projected increases in precipitation account for the increase in total streamflow. Despite the contrasts in climate and hydrological regimes, both catchments are expected to respond similarly to future climate change, especially through the first half of the 21 st century. 
In the eastern Dudh Koshi catchment in Nepal, Shea et al. (2015a) suggest sustained mass loss from glaciers in the Everest region through the 21st century based on RCP 4.5 and RCP 8.5 climate projections. Similarly, Bajracharya et al. (2014) reported a loss of glacier area of $23 \%$ in Bhutan and 25\% in Nepal between 1980 and 2010. How and when the loss of glaciers will impact downstream availability of water is an important area for further research.

Hydrological models have been used to assess the likely impact of climate change on water resources in Pakistan (Ashraf 2013) and in the Koshi River Basin in Nepal (Bharati et al. 2014). Bharati et al. (2014) projected increased flow volumes during the monsoon and post-monsoon and decreased flow volumes during the winter and pre-monsoon seasons, with greater impacts likely in certain seasons and sub-basins.

Soncini et al. (2015) have found similar results for the Shigar watershed (which includes the Baltoro watershed), projecting mostly increases in flow until the end of the century and speculating on the potential for slight decreases thereafter, once ice volumes have diminished. In this catchment, changes in precipitation will not compensate for ice loss in the long run. Across the three different RCPs presented in this study, the differences in streamflow change are strikingly small. The authors showed that increases in both temperature and winter precipitation cause streamflow increases to begin earlier, when glacier and snow begin to melt. This is most dramatic for RCP 8.5, in which two of three General Circulation Models (GCMs) show significant flow increases beginning in April instead of June. Other RCPs also show a shift to the earlier onset of increased flow-and this shift gets stronger toward the end of the century. However, one of the GCMs shows a very different pattern, with flows decreasing in spring and increasing slightly in all other months.

Ragettli et al. (2013) have showed that for the Hunza basin simulated decadal mean runoff is relatively constant (with projections until 2050), but strongly contrasting changes occur in some of the sub-basins. Some models showed flow volume decreasing by as much as $50 \%$ due to decreases in glacial melt, while others showed flow volume increasing due to increases in snowmelt, precipitation, and temperature. In the basin areas, with projections of decreased flow, the most pronounced reductions occur from June to September. The annual peak runoff is projected to occur in June/July, earlier than the July/August peak of the control period.

In the Lhasa basin, Prasch et al. (2013) have made hydrological projections by forcing a glacio-hydrological model with the IPCC Special Report on Emissions Scenarios (SRES) scenarios. The authors found that the contribution of glacial melt to total runoff will remain almost stable until 2080, although there will be a slight increase during a short period in the spring. By contrast, the contribution of snowmelt to runoff will generally decrease in the Lhasa basin, resulting in changes to water availability. Additionally, the increased evapotranspiration accompanying rising air temperatures will also reduce water availability. However, in contrast, regional vegetation greening observed in Tibetan Plateau (TP) is likely to slow warming rates (Box 8.1).

\section{Box 8.1 Implications of landscape-level vegeta- tion change for evaporation}

In recent decades, vegetation changes across the Tibetan Plateau (TP) have shown significant spatial variation. Decreasing trends in Normalized Difference Vegetation Index (NDVI) during the summer growing season have been noted in the southwest, whereas obvious greening was observed in the northeast based on existing global NDVI datasets (Fig. 8.3). Due to warming trends and the grazing-to-grassland project implemented by the Chinese government, regional greening is confirmed by observed NDVI. Despite the warming effects of reduced albedo resulting from increased NDVI, the cooling effects of enhanced evapotranspiration (ET) are dominant in the TP, where ET is believed to be relatively high even at low temperatures (Shen et al. 2015). Greening with increasing NDVI as the proxy is believed to have cooling effects on surface temperatures due to enhanced ET. This is supported by the significant negative correlation between NDVI and daily max temperatures at 55 meteorological stations across the TP. By means of the Weather Research and Forecasting (WRF) model, an increase of NDVI by 0.1 is estimated to result in an increase in ET by $\sim 0.5 \mathrm{~mm} \mathrm{~d}^{-1}$ and a decrease in albedo by 0.01 . Thus, regional vegetation greening is not only beneficial to ecosystem processes, but also to slowing warming rates Shen et al. (2015).

Based on their review of the impacts of climate change on the Indus, Ganges, and Brahmaputra River Basins, Nepal and Shrestha (2015) noted an increase in glacier melt and snowmelt from 2000s to approximately mid-century, which is then followed by a decrease. Although, increases in meltwater are likely for the next few decades, meltwater volume is likely to decrease abruptly once glacial storage is reduced. Nevertheless, further studies are required to understand intra-annual changes and the impact of extreme events on meltwater volumes. Changes in extreme hydrological events in the Indus, Ganges, and Brahmaputra basins are insufficiently studied. As an increase in precipitation is generally projected, it is highly likely that precipitation extremes - and associated extreme discharges - may increase as well. Soncini et al. (2015) used downscaled GCM data to force a semi-distributed model to conduct a 
Fig. 8.3 NDVI changes in the growing season (MaySeptember) across the Tibetan Plateau over the past three decades. (a) Trend in the growing season NDVI at a regional scale during the periods of 1982-2010, 1982-1999, and 2000-2010. $* * * \mathrm{P}<0.01 ; * * \mathrm{P}<0.05$ $* \mathrm{P}<0.10$. Trends with no asterisk are not significant $(\mathrm{P}>0.10)$. (b-f) Spatial distribution of NDVI trends from different datasets examining different periods (Source Reprinted from "Evaporative cooling over the Tibetan Plateau induced by vegetation growth" by Shen, M. et al., 2015, Proceedings of the National Academy of Sciences, 112(30), p. 9300 . Copyright (C) 2015 by the National Academy of Sciences of the United States of America) (a)

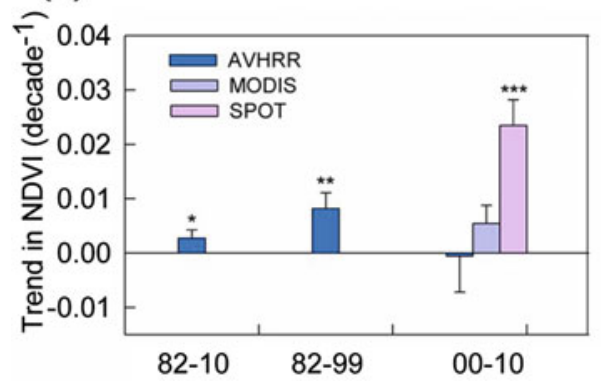

(c)

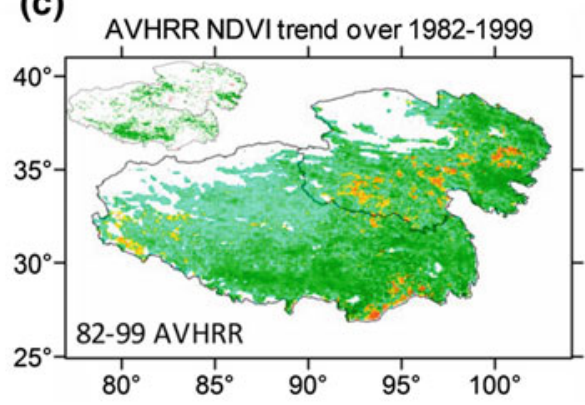

(e)

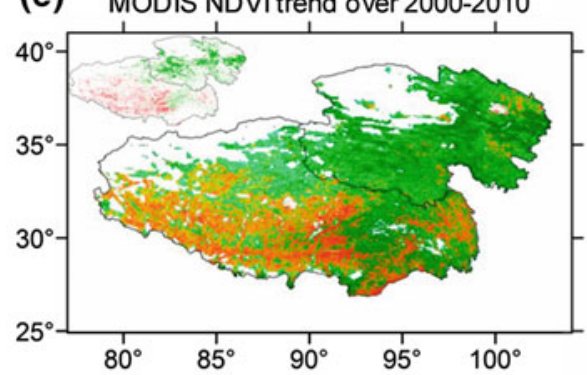

(b)

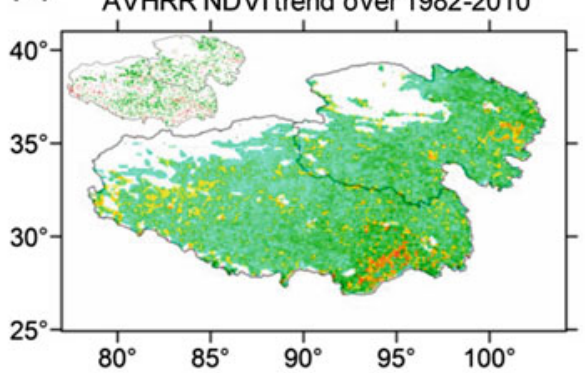

(d)

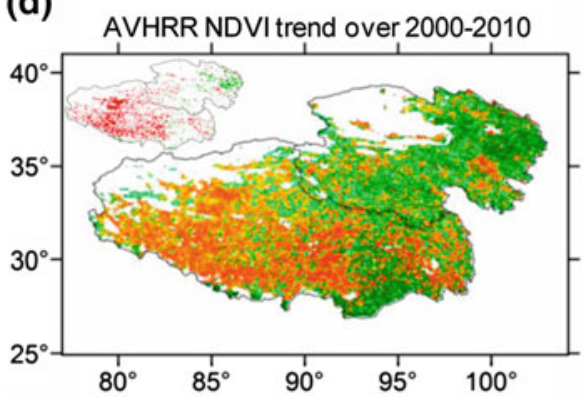

(f) SPOTNDVI trend over 2000-2010

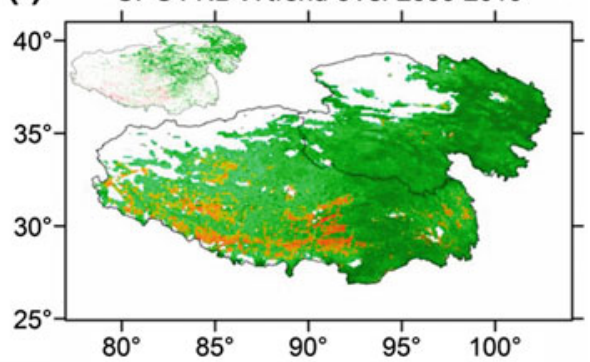
$\begin{array}{llllll}-0.05-0.02-0.01-0.005 & 0 & 0.005 & 0.01 & 0.02 & 0.05 \\ \text { (decade }^{-1} \text { ) }\end{array}$

basic analysis of changes in extreme discharges in the Shigar catchment. Most models indicated increased discharge for the flow-return periods analyzed, indicating the potential for heavier floods during the flood season from June to October.

\subsection{Water Use in the Hindu Kush Himalaya}

There are wide variations in water endowments in $\mathrm{HKH}$ countries in terms of per capita availability, contribution from surface and groundwater sources, as well as with regards to whether or not the water originated within the geographical boundaries of the country or, for that matter, within the HKH. For instance, upstream countries like Bhutan and China generate all their water within their own geographical boundaries, while the downstream country of Bangladesh gets over $90 \%$ of its water from beyond its geographical boundaries. The very nature of upstream-downstream linkages and water distribution across the countries makes it imperative that upper and lower riparian communities cooperate in sharing water equitably.

As seen in Table 8.2, total renewable water availability in the eight countries that constitute the $\mathrm{HKH}$ is $7745.5 \mathrm{~km}^{3}$ (AQUASTAT, FAO 2016a). Figures 8.4, 8.5 and 8.6 show the distribution and per capita availability and use across the eight countries of the $\mathrm{HKH}$ region. Of the total water resources, $1597.8 \mathrm{~km}^{3}(20.62 \%)$ is used annually for various purposes. Some of this usage is consumptive in nature (for agriculture, drinking, and domestic use), as opposed to the largely non-consumptive use in sectors like hydropower.

Table 8.3 shows the sectoral water use in various countries in the region, but for reporting reasons, these do not precisely correspond to the HKH. As with water-resource endowments, there are also wide variations in terms of total volume and per capita water withdrawal, contribution of surface and groundwater to total water withdrawals, and percentage of water withdrawals from the total renewable freshwater available. For instance, per capita water 
Table 8.2 Water-resource availability in HKH countries

\begin{tabular}{|c|c|c|c|c|c|c|c|c|}
\hline Country & $\begin{array}{l}\text { Long-term } \\
\text { average annual } \\
\text { precipitation in } \\
\text { depth } \\
\text { (mm/year) }\end{array}$ & $\begin{array}{l}\text { Long-term } \\
\text { average annual } \\
\text { precipitation in } \\
\text { volume }\left(\mathrm{km}^{3} /\right. \\
\text { year) }\end{array}$ & $\begin{array}{l}\text { Total internal } \\
\text { renewable } \\
\text { water } \\
\text { resources } \\
\text { (IRWR) }\left(\mathrm{km}^{3} \text { / }\right. \\
\text { year) }\end{array}$ & $\begin{array}{l}\text { Total } \\
\text { renewable } \\
\text { water } \\
\text { resources } \\
\left(\mathrm{km}^{3} / \text { year }\right)\end{array}$ & $\begin{array}{l}\text { Total } \\
\text { renewable } \\
\text { surface } \\
\text { water } \\
\left(\mathrm{km}^{3} / \text { year }\right)\end{array}$ & $\begin{array}{l}\text { Total } \\
\text { renewable } \\
\text { groundwater } \\
\left(\mathrm{km}^{3} / \text { year }\right)\end{array}$ & $\begin{array}{l}\text { Dependency } \\
\text { ratio }(\%)\end{array}$ & $\begin{array}{l}\text { Total } \\
\text { renewable } \\
\text { water } \\
\text { resources per } \\
\text { capita }\left(\mathrm{m}^{3} /\right. \\
\text { inhab/year) }\end{array}$ \\
\hline Afghanistan & 327 & 213.3 & 47.15 & 65.370 & 55.68 & 10.65 & 29 & 2,019 \\
\hline Bangladesh & 2,320 & 334 & 105 & $1,226.6$ & 1,206 & 21.12 & 91.4 & 8,343 \\
\hline Bhutan & 2,200 & 84.5 & 78 & 78 & 78 & 8.1 & 0 & 109,244 \\
\hline China & 645 & 6,189 & $2,812.4$ & $2,839.7$ & $2,739.0$ & 828.8 & 1 & 2,079 \\
\hline India & 1,170 & 3,846 & 1,446 & 1,911 & 1,869 & 432 & 31 & 1,582 \\
\hline Myanmar & 2,341 & 1,415 & $1,002.8$ & $1,167.8$ & 1,157 & 453.7 & 14.1 & 24,537 \\
\hline Nepal & 1,500 & 220.77 & 198.2 & 210.2 & 210.2 & 20.0 & 5.71 & 7,142 \\
\hline Pakistan & 494 & 393.3 & 55.0 & 246.8 & 239.2 & 55 & 78 & 1,474 \\
\hline
\end{tabular}

Source FAO (2016a)

Fig. 8.4 Total per capita renewable water resources and withdrawals by country (Source FAO 2016a, AQUASTAT http:// www.fao.org/nr/water/aquastat/ water_res/index.stm)

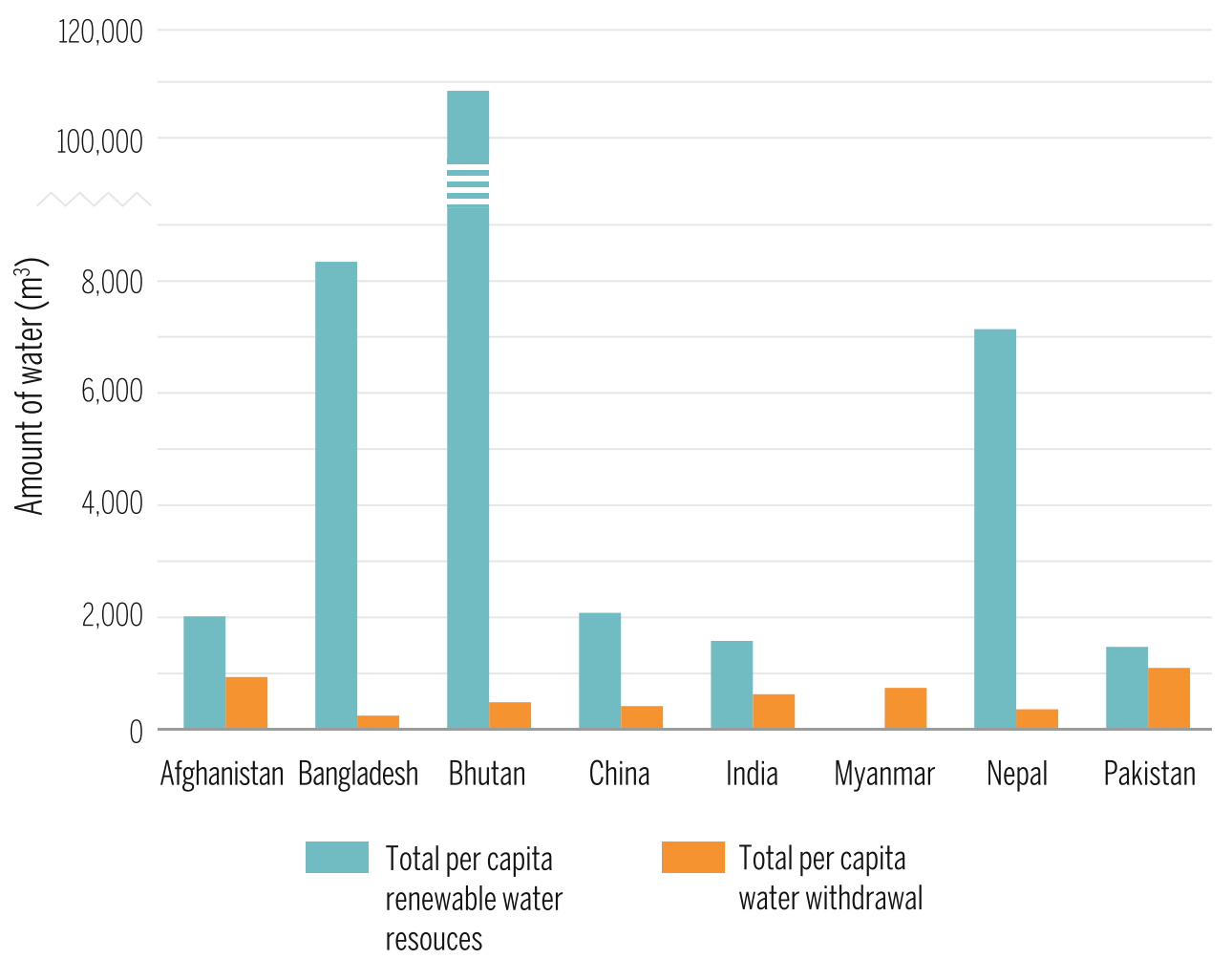

withdrawals vary from $1096 \mathrm{~m}^{3} /$ year in Pakistan to a low of $247 \mathrm{~m}^{3} /$ year in Bangladesh. At the same time, Pakistan withdraws $74 \%$ of its renewable freshwater resources, while Bhutan withdraws less than $0.5 \%$ annually. Groundwater accounts for $79.4 \%$ of water withdrawal in Bangladesh and for about $33 \%$ of water withdrawal in India and Pakistan.

Figure 8.7 shows the total water withdrawals and withdrawals by sector in the HKH countries. In spite of their varied water withdrawal, what remains constant across all of these countries is that the largest proportion of withdrawals is used for agriculture. Agriculture accounts for close to $90 \%$ of water withdrawal in all HKH countries with the exception of China, where $65 \%$ of withdrawal is applied to agriculture. By contrast, 25\% of China's water withdrawal is used for industrial purposes, while industry accounts for less than $10 \%$ of water withdrawal in other countries, reflecting China as the most industrialized country in the HKH. Overall, given the twin effects of anthropogenic and climate induced changes, it is believed that water use in the HKH is at a critical crossroad, and decisions regarding water management and governance taken now will have long-term implications for the future (Mukherji et al. 2015). 


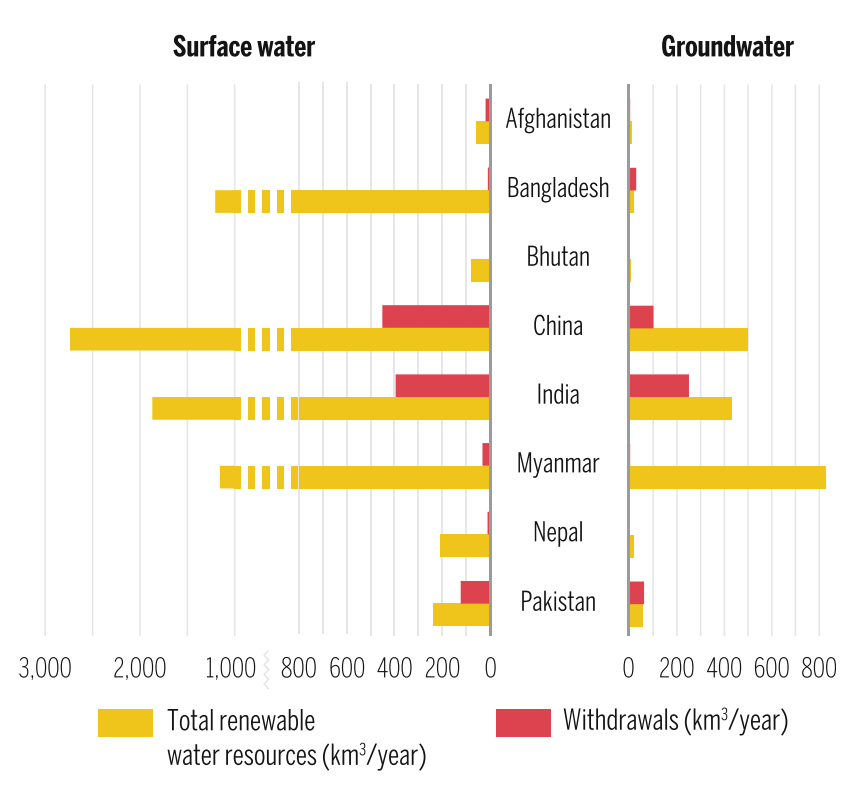

Fig. 8.5 Total renewable water resources and withdrawals by surface water versus groundwater by country (Source FAO 2016a, AQUASTAT http://www.fao.org/nr/water/aquastat/water_res/index.stm)

\subsubsection{Agricultural Water Use in the Mountains, Hills, and Plains of HKH River Basins}

As is the case in most other regions of the world, agriculture accounts for the highest proportion of water withdrawal in the HKH (Table 8.3). Agriculture in the HKH varies according to altitude. Mountains, mid-hills, and plains (including foothills of the Himalayas) offer three distinct agricultural systems. In the high mountains, agriculture is dominated by livestock rearing and orchard cultivation, while in the mid-hills and the plains, cereal crops take precedence. In general, agriculture in the mountains and mid-hills tends to be rainfed, while that of the plains is mostly irrigated (Table 8.4, Fig. 8.8).

\subsubsection{Hill and Mountain Agricultural Water Use}

Most HKH countries maintain the centuries-old tradition of farmer-managed hill and mountain agriculture. While mostly rainfed, these farms are also irrigated seasonally through local streams, springs, and glacier and snowmelt. In the northern mountains of Pakistan (comprised of Gilgit, Baltistan, Chitral, and Upper Dir), there are broadly two types of mountain irrigation systems - those sourced by snowmelt and those by streamflow or springwater (Vincent 1995). There is a large number of detailed and structured case studies of mountain agriculture from different parts of northern Pakistan, e.g. Hunza (Kreutzmann 2011; Parveen et al. 2015), Nanga Parbat (Nüsser and Schmidt 2017) and Chitral (Nüsser 2001), that document continuity and change in mountain agriculture and irrigation. All these studies underpin the critical role of mountain communities in managing their irrigation systems through framing and implementation of context-specific rules.

Snowmelt, streamflow, and/or springwater are diverted through channels along the mountain slopes to the valley bottom where fruit, vegetable, and other crops are grown.
Fig. 8.6 Freshwater withdrawals as proportion of total renewable water resources by country (Source FAO 2016a, AQUASTAT http://www.fao.org/ nr/water/aquastat/water_res/ index.stm)

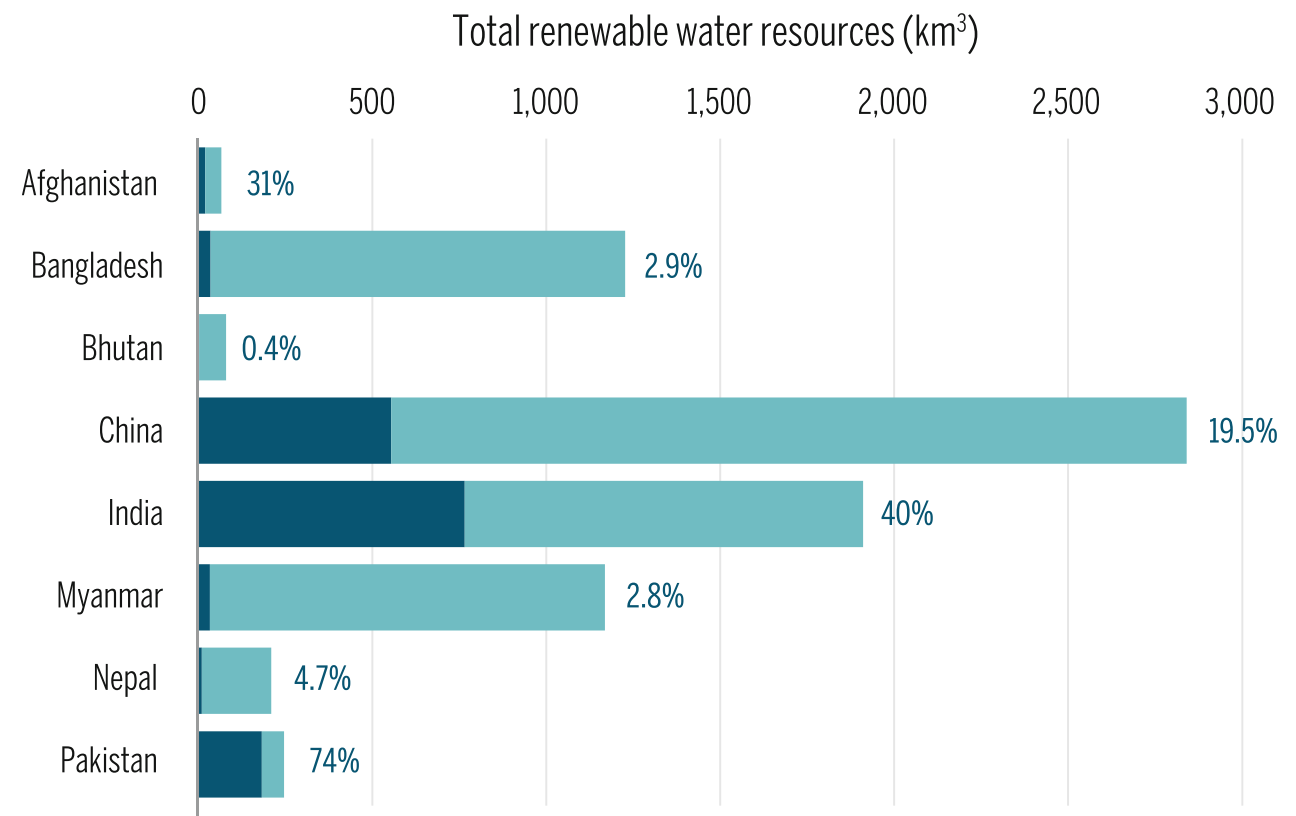

Freshwater withdrawal (\%) as proportion of total renewable water resources 
Table 8.3 Sector-wise water withdrawals in HKH countries

\begin{tabular}{|c|c|c|c|c|c|c|c|c|}
\hline $\begin{array}{l}\text { Country; } \\
\text { Year of data } \\
\text { referenced }\end{array}$ & $\begin{array}{l}\text { Total water } \\
\text { withdrawal } \\
\left(\mathrm{km}^{3} / \text { year }\right)\end{array}$ & $\begin{array}{l}\text { Agricultural } \\
\text { water } \\
\text { withdrawal } \\
\left(\mathrm{km}^{3} / \text { year) }\right.\end{array}$ & $\begin{array}{l}\text { Municipal } \\
\text { water } \\
\text { withdrawal } \\
\text { ( } \mathrm{km}^{3} / \text { year) }\end{array}$ & $\begin{array}{l}\text { Industrial } \\
\text { water } \\
\text { withdrawal } \\
\left(\mathrm{km}^{3} / \text { year) }\right.\end{array}$ & $\begin{array}{l}\text { Surface } \\
\text { water } \\
\text { withdrawal } \\
\left(\mathrm{km}^{3} / \text { year) }\right.\end{array}$ & $\begin{array}{l}\text { Groundwater } \\
\text { withdrawal } \\
\left(\mathrm{km}^{3} / \text { year }\right)\end{array}$ & $\begin{array}{l}\text { Per capita } \\
\text { water } \\
\text { withdrawal per } \\
\text { inhabitant } \\
\left(\mathrm{m}^{3} / \text { year }\right)\end{array}$ & $\begin{array}{l}\text { Freshwater } \\
\text { withdrawal as \% } \\
\text { of total renewable } \\
\text { water resources }\end{array}$ \\
\hline $\begin{array}{l}\text { Afghanistan; } \\
\text { (1998) }\end{array}$ & 20.37 & 20.00 & 0.20 & 0.17 & 17.24 & 3.042 & 937 & 31 \\
\hline $\begin{array}{l}\text { Bangladesh; } \\
\text { (2008) }\end{array}$ & 35.87 & 31.5 & 3.6 & 0.77 & 7.39 & 28.48 & 247 & 2.93 \\
\hline $\begin{array}{l}\text { Bhutan; } \\
\text { (2008) }\end{array}$ & 0.338 & 0.318 & 0.017 & 0.003 & 0.338 & 0 & 482 & 0.43 \\
\hline $\begin{array}{l}\text { China; } \\
\text { (2005) }\end{array}$ & 554.1 & 358.02 & 67.53 & 128.55 & 452.7 & 101.4 & 414 & 19.5 \\
\hline India; (2010) & 647.5 & 688 & 56 & 17 & 396.5 & 251 & 630 & 40 \\
\hline $\begin{array}{l}\text { Myanmar; } \\
(2000)\end{array}$ & 33.23 & 29.575 & 3.323 & 0.332 & 30.240 & 2.991 & 739 & 2.8 \\
\hline $\begin{array}{l}\text { Nepal; } \\
(2006)\end{array}$ & 9.497 & 9.32 & 0.147 & 0.0295 & $8.444^{b}$ & $1.053^{\mathrm{a}}$ & 359 & 4.7 \\
\hline $\begin{array}{l}\text { Pakistan; } \\
\text { (2008) }\end{array}$ & 183.421 & 172.371 & 9.650 & 1.4000 & 121.9 & 61.6 & 1,096 & 74 \\
\hline
\end{tabular}

Source FAO (2016b)

${ }^{a}$ Government of Nepal 2016, Groundwater Resources Development Board, Ministry of Irrigation, (12 June 2016) retrieved from http://www. gwrdb.gov.np/hydrogeological_studies.php

${ }^{\mathrm{b}}$ Derived by subtracting groundwater withdrawals from total water withdrawals

These irrigation systems are unique in that each water-source channel has its own command area, water users frame their own rules, and that these irrigation systems are maintained by active participation of water users with almost no government involvement (Kreutzmann 2011).

While irrigation is reliable during the spring and summer seasons, it is less so in winter due to reduced snowmelt. Cropping patterns are, therefore, adjusted accordingly. From sowing to harvesting, women are actively involved in various aspects of the agricultural practices in these areas (Ishaq and Farooq 2016). Although water distribution may or may not be equitable, customary rules of distribution and maintenance are clearly laid out and followed by water users (Ostrom and Gardner 1993). In general, water utilization in these systems has remained well within the limits of available water resources (Nüsser 2001). There have been some modifications in social organization of water users and associated rules in response to changes in spatial patterns of irrigated mountain farming (Kreutzmann 2011; Thapa et al. 2016). In Afghanistan and highland Balochistan, karezes are traditional irrigation systems wherein shallow tunnels tap underground aquifers and convey water to fields downstream (Box 8.2). Another system of irrigation in the hill regions of western $\mathrm{HKH}$ is referred to as spate irrigation, in which flood water is harvested and managed for irrigation.
Box 8.2 Glacier-fed irrigation systems in Hunza and Ladakh in Upper Indus; karezes and spate irrigation in Afghanistan and Pakistan

In the Upper Hunza region of Pakistan (Kreutzmann 2011; Parveen et al. 2015) and in the trans-Himalayan part of Ladakh in India, glacier melt and snowmelt is the only source of irrigation. Glacio-fluvial dynamics affect these irrigation practices, and local communities adapt to these changes in different ways. In Hopar village in the Karakorum Range in Pakistan, it is not the quantity or timing of meltwater discharge that affects irrigation decisions but other factors such as water quality, reliable access, and control of turbulent flow. In Ladakh, the irrigated area is shrinking-not necessarily as a direct consequence of changing hydrology or glacial melt, but because of changing livelihood strategies involving more off-farm employment (Butz 1989; Nüsser et al. 2012). In recent years, late melting of glaciers due to high climatic snow line has made seasonal water scarcer. In response, communities have come together to create artificial glaciers on southern slopes, both as a strategy to cope with seasonal water scarcity and a long-term adaptation to climate change. Since these glaciers are 
constructed at lower altitudes and on south-facing slopes, water starts melting from April, thereby affording a longer growing season for the cultivators (Nüsser and Baghel 2016).

In highland Balochistan and Afghanistan, karez irrigation has been the backbone of rural water management and agriculture for more than two millennia. A karez is an underground aqueduct that passively taps groundwater in the piedmont of the arid and semi-arid highlands. The key physical advantages of the system are that it minimizes evaporative loss and delivers water from mountain aquifers to valley floor communities. Karezes require annual maintenance, and karez communities have developed strong social capital to enable provision of labor and resources for their upkeep. However, karezes have increasingly come under threat across Balochistan because of uncontrolled pumping with high-power electric water pumps. In Afghanistan, more than three decades of war has also taken a toll on the physical and social infrastructure of karezes. In the Mastung district in Balochistan, for example, prior to the 1980 s there were 365 karezes; today there are no more than ten in operation. The drying up of karezes has numerous damaging consequences, including the breakdown of the rural social capital anchored in the karez infrastructure. Despite a temporary increase in agricultural productivity due to availability of on-demand water, there is a long-term decline of agriculture and rural livelihoods due to groundwater depletion, as in the Quetta valley of Balochistan. This enhances power of the rural elites who own the electric pumps, which mine the groundwater and deprive hundreds of karez shareholders of their previously held water rights. These have significantly contributed to rural pauperization and rural-to-urban migration in the region. Furthermore, long-term questions about the sustainability of human life in the arid highlands remain to be addressed, as groundwater depletes from one valley to the next due to over-pumping.

Spate irrigation is common in the drier parts of western $\mathrm{HKH}$, especially in Balochistan province of Pakistan and in Afghanistan. Spate irrigation uses flood water generated from an upstream hill slope that is then stored as soil moisture or collected from ephemeral streams in adjacent low-lying valley bottom. This soil moisture is then channeled through rudimentary and locally constructed infrastructure in order to cultivate crops during dry months (Mehari et al. 2007). These systems are called "sailaba" in Balochistan (van Steenbergen 1997). It is estimated that roughly 1.45 million hectares of land is under such seasonal flood irrigation (Khan 1987); yet these systems that cater to the poorest of the poor in the hills and mountains do not receive adequate attention. These systems, much like the other systems of hill and mountain irrigation described above, are managed by farming communities who have adjusted to inherent uncertainty of spate irrigation through rules and regulations that define access and norms for water sharing. Typically, local varieties like drought-resistant sorghum, millets, and wheat are cultivated, and yields are low. This, coupled with inherent uncertainty of occurrences and magnitudes of floods, means that even this minimum yield is not assured every year. Cyclic outmigration of labor is, thus, quite common (van Steenbergen 1997). There are ongoing initiatives to "modernize" these systems, but such modernization efforts will not succeed unless traditional norms and practices are understood and incorporated in new designs.

Nepal is also known for its centuries-old, farmer-managed irrigation systems (Box 8.3). About $70 \%$ of irrigation systems in Nepal are operated through farmer-managed irrigation systems (FMIS) (Pradhan 2000). Communities build water channels and weirs to divert water from spring-fed streams for growing paddy in monsoon season and, occasionally, one additional crop during the dry season. Intricate rules govern issues like water distribution, maintenance of infrastructure, and conflict resolution-and evidence shows that these systems have endured for centuries and adapted to changing circumstances (Thapa et al. 2016). Similar spring- and stream-fed irrigation systems are also found in India's western and central Himalayas (Baker 2005). According to Mollinga (2009), the share of irrigated land served by FMISs in India has declined from $18.5 \%$ in 1961 to $6.8 \%$ in 1991. Other studies have reported that irrigation efficiency is higher in FMISs than in state-managed irrigation systems in the central Indian Himalaya (Kumar et al. 2006).

\section{Box 8.3 Farmer-managed irrigation systems in Nepal}

Nepal has a long history of FMISs, in which farmers take sole responsibility for operating and maintaining their irrigation systems. In the absence of strong government intervention in the past, FMISs slowly developed through the collective efforts of farmers looking to irrigate their land. These FMISs provide irrigation services to about two-thirds of the country's total irrigated area-a little more than 1.2 million hectares (Pradhan 2000). FMISs are characterized by 
the use of low-cost technology appropriate for heterogeneous local conditions, autonomous decision-making suited to local contexts, and collective action by farmers for the operation and maintenance of the irrigation systems (Yoder 1986; Ostrom and Benjamin 1993).

While many FMISs have survived decades of changes to hydro-climatic, social, institutional, and policy conditions (such as, government support for operation, maintenance, and infrastructure, as well as registration in FMIS inventories), their performance is increasingly under stress (Janssen and Anderies 2013). Water availability for irrigation is affected by variability in the intensity and timing of precipitation. Impacts include more flooding and erosion damage to irrigation intake points and canals and, during the dry season, less water available for irrigation and increased competition for it due to prolonged drought (Bastakoti et al. 2015). These challenges are further compounded by socio-economic and institutional changes.

In FMIS, men have traditionally played a dominant role in the maintenance and operation of irrigation systems. But since men are migrating out of the countryside in large numbers and educated youth seem to have less interest in water management, an increasing number of women play a larger role in agriculture and water management, despite being unaccustomed to such tasks and often having limited experience. A recent study by Pokhrel (2014) considered why some FMISs have survived and others have declined or disappeared. The results showed the importance of adaptability in institutions concerned with the use and management of shared resources. This adaptability was characterized by a perceived fairness and bounded flexibility of the institutionsand the survival of an FMIS was dependent on this capacity to adapt to both climate change and to changes in gender relations.

In the northeastern Indian Himalaya and in the highlands of Bangladesh and Myanmar, farming systems are distinct from elsewhere in the $\mathrm{HKH}$ and shifting cultivation remains the preferred practice for the numerous ethnic groups in the region (Box 8.4).

\section{Box 8.4 Changing contours of shifting cultivation in North East India, Chittagong Hill tracts, and Myanmar}

There are not many studies on water availability and use in the eastern Himalaya, a region known to be abundant in water resources, feeding four major river systems in the HKH - the Brahmaputra, Ganges, Irrawaddy, and Salween. However, we do know that shifting cultivators in this region have for centuries used water resources on a sustainable basis, employing indigenous traditional knowledge and practices-such as the zabo farming system in Nagaland, the water management that sustains the rice and fish culture of Apatani tribes in Arunachal Pradesh, the bamboo drip-irrigation system of Meghalaya (Singh and Gupta 2002), or the Jhiri system in Chittagong Hill Tracts (CHT) of Bangladesh. Risk-aversion attributes are inherent in shifting cultivation practices. Maintaining high crop diversity as practiced by shifting cultivators helps withstand weather stresses and, hence, reduce the risk of crop failure (Aryal and Choudhury 2015).

In terms of agriculture, many shifting cultivators in the eastern Himalayas are converting to either settled agriculture or to growing more cash root crops on sloping lands. Cultivation on sloping lands without soil and water conservation measures has led to soil erosion and the degradation of ecosystem services. Rasul (2009) reported approximately 89-109 tons/ha/year of soil loss from the cultivation of annual crops (mainly ginger, colocasia, and turmeric) on sloping lands when conventional hoeing tillage methods were applied. With mulching, soil erosion was reduced to about 35 tons/ha/year. In northeast India, the fallow-management practices of shifting cultivators through retention of selective multipurpose species, for example Alnus nepalensis, has long-term implications for the provisioning and regulating of ecosystem services like water security that accrue from them (Singh and Choudhury 2015). There are many good sustainable land and water management practices in the region - both traditional and new-but they have yet to be evaluated, documented, and shared.

While the exact contours of mountain and hill irrigation systems may differ in terms of water sources, distribution, and management, there are certain aspects of agricultural water management that are consistent across the entire HKH. For example, indigenous systems of water management have developed effective methods for cooperating, sharing, and resolving disputes - and these local institutions have withstood change and adapted accordingly.

In the past two or three decades, there has been a contraction in hill and mountain agriculture due to a number of factors-both climate and non-climate induced. For instance, in the upper reaches of the Indus, canal infrastructure built for the intake of glacial melt has become 
Fig. 8.7 Total water withdrawals and withdrawals by sector by country country (Source FAO 2016b, AQUASTAT http:// www.fao.org/nr/water/aquastat/ water_use/index.stm)

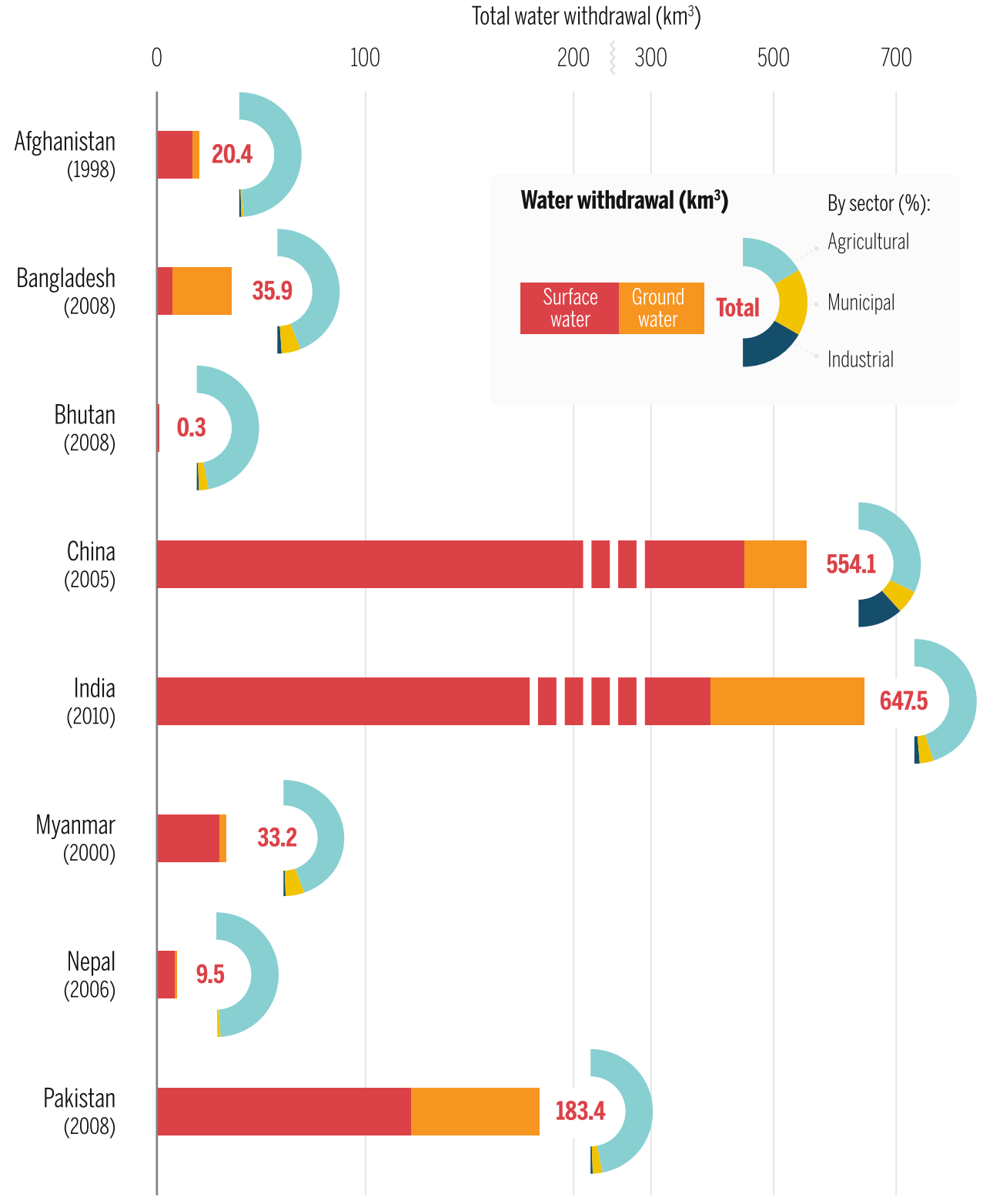

dysfunctional due to glacial retreat in some regions and glacial surge in others. This necessitates the rebuilding of the entire infrastructure, which is both costly and labor-intensive, beyond the reach of many communities, and thus contributing to outmigration. Extreme weather events, such as flash floods, have created additional risks to irrigation infrastructure in these regions. Many FMIS in Nepal and India have also shrunk in size due to urbanization and predominantly male out-migration.

However, irrigation systems are being adapted to changes in various ways. New technologies are being used (including groundwater or surface-water pumps and greenhouses for vegetable-growing); new niche and high-value crops are being introduced (including vegetables, coffee, and nuts). Due to male out-migration, women are increasingly managing these systems, but are yet to receive de-jure land and water rights.

Increased out-migration also offers new opportunities. For example, in some instances, remittances are being used for improving agricultural water management-through investment in vegetable greenhouses, drips, and sprinklers. However, in other instances, entire farms are being abandoned and native vegetation is reclaiming previously cultivated terraces. Hill and mountain irrigation is in transition, and how this transition is handled will be crucial to future water management and to the options for long-term livelihood. 
Table 8.4 Rainfed and irrigated areas in the hills, mountains, and plains of the HKH

\begin{tabular}{|c|c|c|c|c|c|}
\hline \multirow[t]{2}{*}{ Country } & \multicolumn{2}{|c|}{$\begin{array}{l}\text { Area under rainfed and } \\
\text { irrigated agriculture in } \\
\text { mountains and hills (ha) }\end{array}$} & \multicolumn{2}{|c|}{$\begin{array}{l}\text { Area under rainfed and } \\
\text { irrigated agriculture in } \\
\text { plains (ha) }\end{array}$} & \multirow[t]{2}{*}{ Source (year of data) Year of data (Source) } \\
\hline & $\begin{array}{l}\text { Rainfed } \\
\text { area } \\
(\% \text { of total } \\
\text { cultivated } \\
\text { area) }\end{array}$ & $\begin{array}{l}\text { Irrigated } \\
\text { area } \\
(\% \text { of total } \\
\text { cultivated } \\
\text { area) }\end{array}$ & $\begin{array}{l}\text { Rainfed } \\
\text { area } \\
(\% \text { of total } \\
\text { cultivated } \\
\text { area) }\end{array}$ & $\begin{array}{l}\text { Irrigated } \\
\text { area } \\
(\% \text { of total } \\
\text { cultivated } \\
\text { area) }\end{array}$ & \\
\hline Afghanistan $^{\mathrm{a}}$ & $\begin{array}{l}3,051,001 \\
(66.7 \%)\end{array}$ & $\begin{array}{l}1,522,585 \\
(33.3 \%)\end{array}$ & $\begin{array}{l}437,169 \\
(22.3 \%)\end{array}$ & $\begin{array}{l}1,526,216 \\
(77.7 \%)\end{array}$ & 2001-02 (Maleta and Favre 2003) \\
\hline Bangladesh $^{\mathrm{b}}$ & $\begin{array}{l}102,790 \\
(72.5 \%)\end{array}$ & $\begin{array}{l}38,850 \\
(27.5 \%)\end{array}$ & $\begin{array}{l}7,806,393 \\
(52.4 \%)\end{array}$ & $\begin{array}{l}7,086,052 \\
(47.6 \%)\end{array}$ & 2012-13 (Bangladesh Bureau of Statistics 2015) \\
\hline Bhutan $^{\mathrm{c}}$ & $\begin{array}{l}50,000 \\
(66.7 \%)\end{array}$ & $\begin{array}{l}25,000 \\
(33.3 \%)\end{array}$ & NA & NA & 2011 (ADB 2014) \\
\hline China $^{\mathrm{d}}$ & $\begin{array}{l}14,680,986 \\
(60 \%)\end{array}$ & $\begin{array}{l}9,842,614 \\
(40 \%)\end{array}$ & NA & NA & $\begin{array}{l}\text { 2012-13 (China Statistical Year Book 2015) for rainfed area and } \\
\text { total cultivated area; } 2005 \text { (FAO AQUASTAT 2016c; Global Map } \\
\text { of Irrigated Area) for irrigated area }\end{array}$ \\
\hline $\operatorname{India}^{\mathrm{e}}$ & $\begin{array}{l}3,216,186 \\
(73.7 \%)\end{array}$ & $\begin{array}{l}1,148,459 \\
(26.3 \%)\end{array}$ & $\begin{array}{l}12,450,814 \\
(31.2 \%)\end{array}$ & $\begin{array}{l}27,396,541 \\
(68.8 \%)\end{array}$ & $\begin{array}{l}\text { 2011-12 (Land Use Statistics, Directorate of Economics and } \\
\text { Statistics, GOI, 2016) }\end{array}$ \\
\hline Myanmar $^{\mathrm{f}}$ & NA & $\begin{array}{l}116,075 \\
\text { (NA) }\end{array}$ & NA & $\begin{array}{l}1,988,040 \\
(\mathrm{NA})\end{array}$ & $\begin{array}{l}\text { 2005, (FAO, AQUASTAT, 2016d, Global Map of Irrigated Area, } \\
\text { FAO) }\end{array}$ \\
\hline $\mathrm{Nepal}^{\mathrm{g}}$ & $\begin{array}{l}870,800 \\
(72.6 \%)\end{array}$ & $\begin{array}{l}328,700 \\
(27.4 \%)\end{array}$ & $\begin{array}{l}338,200 \\
(25.6 \%)\end{array}$ & $\begin{array}{l}984,800 \\
(74.4 \%)\end{array}$ & 2011-12 (Government of Nepal 2012-13) \\
\hline Pakistan $^{\mathrm{h}}$ & $\begin{array}{l}753,171 \\
(41.8 \%)\end{array}$ & $\begin{array}{l}1,034,994 \\
(57.4 \%)\end{array}$ & $\begin{array}{l}3,402,833 \\
(20 \%)\end{array}$ & $\begin{array}{l}13,801,888 \\
(80.0 \%)\end{array}$ & 2010 (Government of Pakistan, Pakistan Agricultural Census 2010) \\
\hline
\end{tabular}

${ }^{a}$ In Afghanistan, mountain area includes Badakshan, Central, Eastern, Southern, and Northern mountains; plains include Turkistan, Herat-Farah, and Helmand river valley

b In Bangladesh, districts of Bandarban, Khagrachari, and Rangamati are classified as hills; the rest of Bangladesh is classified as plains. In table, gross cropped area has been subtracted from total irrigated area (sum total of irrigated area in different seasons) in order to derive rainfed or non-irrigated area

${ }^{\mathrm{c}}$ Bhutan is considered to be comprised of hills and mountains only

${ }^{\mathrm{d}}$ In China, Gansu, Qinghai, Sichuan, Tibet, Yunnan, and Xinjiang provinces are considered parts of the HKH

${ }^{\mathrm{e}}$ In India, the Indo-Gangetic states (Punjab, Haryana, Uttar Pradesh, Bihar, and West Bengal except the Darjeeling district) and Assam (excluding Karbi Anglong and North Cachar hills) are classified as plains. The states of Jammu and Kashmir, Himachal Pradesh, Uttarakhand, Meghalaya, Tripura, Manipur, Mizoram, Nagaland, Arunachal Pradesh, Darjeeling district of West Bengal, Karbi Anglong, and North Cachar hills of Assam are considered hills and mountains

${ }^{\mathrm{f}}$ In Myanmar, Chin, Kachin, and Shan provinces are classified as hills; the rest of the provinces are considered plains. Data on cultivated area in Myanmar's hills and plains provinces are not available

${ }^{\mathrm{g}}$ In Nepal, all Terai districts are classified as plains; the rest of the country is classified as hills and mountains

${ }^{\mathrm{h}}$ In Pakistan, Khyber Pakhtunkhwa Province is classified as comprised of hills and mountains only; the other provinces (Punjab, Sindh, and Baluchistan) are classified as plains

$\mathrm{NA}=$ Not available

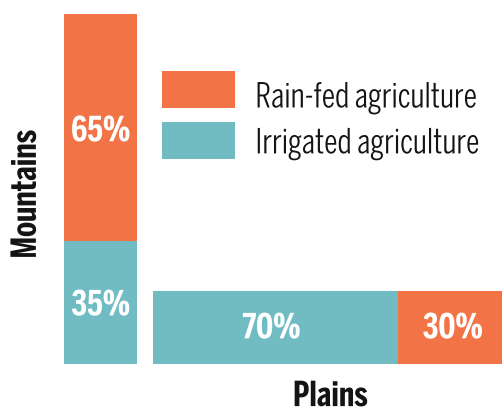

Fig. 8.8 Rainfed versus irrigated agricultural area in the mountains versus the plains. (Sources See Table 8.4)

\subsubsection{Agricultural Water Use in the Plains of HKH River Basins}

The extent and sources of irrigation vary; some areas like the Indo-Gangetic Plains in Pakistan, India, and Bangladesh are intensely irrigated, while those in the Nepal Terai are not. While most of these plains have canal infrastructure, groundwater has emerged as the main source of water for irrigation. The associated challenges of irrigation in the plains are:

- over-extraction of groundwater compounded with inefficient use of surface water in areas where water is already scarce (like the Indus and western Ganges); 
- under-development of irrigation potential in areas of abundance (like the eastern Ganges, Terai in Nepal, and parts of eastern India); and

- increased frequency and intensity of flood drought cycle.

India is the largest user of agricultural groundwater in the world. It is estimated that there are over 20 million groundwater wells (GOI 2011), of which more than $95 \%$ are privately owned by smallholder farmers. These provide a range of livelihoods and productivity benefits to millions of smallholder farmers in India. However, within the overall groundwater story of the Gangetic plains in India, there are two distinct subplots.

The first, and rather well known, is the story of groundwater overexploitation and its consequences. This is broadly the situation in states like Punjab, Haryana, and western Uttar Pradesh. These states have a number of things in common. They receive low to medium rainfall, averaging from 200 to $1000 \mathrm{~mm}$ per year. Even though they have alluvial aquifers, recharge is limited by the total amount of rainfall and is, therefore, inherently low. The majority (over $70-80 \%$ ) of all water extraction mechanisms are operated by electricity. Farmers get electricity either free of cost (Punjab) or at highly subsidized rates (Haryana, Uttar Pradesh). In all of these states, rural poverty is comparatively low and below the all-India average. Groundwater and electricity are major political issues in all of these states, and both remain at the center of vote bank politics. The discourse on overexploitation is fairly well known and documented (Janakarajan and Moench 2006; Moench 2007; Sarkar 2011).

But there is a second, lesser-known subplot to this story - one in which groundwater development falls far short of potential groundwater reserves, even though rainfall and natural recharge is very high. In these areas, abundant groundwater resources coexist with high costs of groundwater extraction, restrictive access policies, and low agricultural growth rates. Here, most pumps run on expensive diesel or whenever farmers get electricity, for which they pay full cost (Shah 2007; Mukherji 2007). These scenarios can be observed in places where rural poverty rates are much higher than the national average and crop productivity is low - more or less all across the eastern Indo-Gangetic belt in India, namely, West Bengal, Bihar, Orissa, and Assam. Much of the eastern Nepal Terai is also part of this story of underdeveloped groundwater resources. However, in some of these parts of eastern $\mathrm{HKH}$, there is a high occurrence of geogenic arsenic and irrigating with arsenic rich water for a sustained period poses the risk of entry of arsenic in the food chain (Box 8.7).

Therefore, agricultural water management in the plains of the $\mathrm{HKH}$ requires different policies for regions where water resources are under stress and those where water resources are abundant. In the former, demand-management measures are required; in the latter, larger investments are necessary to tap untapped water resources for future agricultural growth.

\subsubsection{Water for Energy}

Unlike water used for agriculture, domestic needs, and in urban sectors, use of water for energy production in not consumptive in nature. However, hydropower projects, including the run of the river projects, which are thought to be the most benign in terms of environmental impacts, can lead to extensive changes in river flow regimes, including timing and seasonality of flow. They can also lead to changes in biodiversity (Grumbine and Pandit 2013) and create conflicts with pre-existing systems of water use, including irrigation (Erlewein 2013). The HKH has a total of 500 gigawatts $(\mathrm{GW})$ of hydropower potential, of which only a small fraction is actually developed (Table 8.5). Figure 8.9 shows these data by country.

The hydropower sector in the HKH suffers from the twin challenges of societal pressure and climate change. The sector faces major challenges due glacial melt induced by climate change. Glaciers across the region, except in the Karakoram (Bolch et al. 2017), are retreating, leading to changes in future hydrological regimes. At the same time, risk of glacial lake outburst floods (GLOFs) and landslides are increasing, putting both existing and planned hydropower plants at risk. Nearly as important as climate-related risks are the societal risks of alienating local people in areas where hydropower projects are constructed. These projects are mostly developed in mountain areas, and mountain people fear, and often rightly so, that even as they bear the environmental and social costs of hydropower, the benefits will go to the people in the plains who get electricity (Bandyopadhyay 2002). As a consequence, most hydropower projects have seen widespread protests from the local mountain communities, especially in India where mechanisms of sharing benefits have not been implemented adequately (Diduck et al. 2013). For managing this risk, governments and hydropower companies need to provide direct and tangible benefits to the local mountain communities.

After a hiatus of more than two decades, hydropower is back on the investment agenda of international financial institutions (Baghel and Nüsser 2010). Hydropower investments are also being financed through Clean Development Mechanism (CDM) in parts of India and China, even though it is not entirely clear that large hydropower dams do indeed meet the goals of CDM (Erlewein and Nüsser 2011). New norms for environmental sustainability and benefit sharing with local communities are being developed with the hope that hydropower projects will be better built than in the past 
Table 8.5 Hydropower potential in eight HKH countries

\begin{tabular}{|c|c|c|c|c|}
\hline Country (1) & $\begin{array}{l}\text { Hydropower potential } \\
\text { (Mega Watt, MW) (2) }\end{array}$ & $\begin{array}{l}\text { Actual hydropower } \\
\text { developed (MW) (3) }\end{array}$ & $\begin{array}{l}\text { Actual generation } \\
\text { in GWh (4) }\end{array}$ & Year (Source of data) (5) \\
\hline Afghanistan & 25,000 & 1,000 & 868.6 & $\begin{array}{l}2006 \text { (Government of Afghanistan, Ministry } \\
\text { of Energy and Water 2006) }\end{array}$ \\
\hline Bangladesh & 1,897 & 230 & 590.1 & $\begin{array}{l}2014 \text { (Bangladesh Power Development } \\
\text { Board 2014) }\end{array}$ \\
\hline Bhutan & 24,000 & 1,615 & 7,748 & $\begin{array}{l}2015 \text { (International Hydropower } \\
\text { Association website, 2015) }\end{array}$ \\
\hline China & 370,000 & 319,370 & $1,128,027$ & $\begin{array}{l}2015 \text { (International Hydropower } \\
\text { Association website, 2015) }\end{array}$ \\
\hline India (all) & 148,701 & 42,848 & 121,894 & $\begin{array}{l}\text { Central Electricity Authority (CEA) as of } \\
\text { 30th June } 2016\end{array}$ \\
\hline \multicolumn{5}{|c|}{ Indian Himalayan States } \\
\hline Assam & 680 & 430 & 1,011 & CEA (2016) \\
\hline $\begin{array}{l}\text { Arunachal } \\
\text { Pradesh }\end{array}$ & 50,328 & 98 & 366 & CEA (2016) \\
\hline $\begin{array}{l}\text { Himachal } \\
\text { Pradesh }\end{array}$ & 18,820 & 1,495 & $9,451.1$ & CEA (2016) \\
\hline $\begin{array}{l}\text { Jammu and } \\
\text { Kashmir }\end{array}$ & 14,146 & $2,274.4$ & $4,798.7$ & CEA (2016) \\
\hline Meghalaya & 2,394 & 356.6 & 257 & CEA (2016) \\
\hline Mizoram & 2,196 & 34 & NA & CEA (2016) \\
\hline Manipur & 1,784 & 82 & 30 & CEA( 2016) \\
\hline Nagaland & 1,574 & 53 & 10 & CEA (2016) \\
\hline Sikkim & NA & 270 & 910 & CEA (2016) \\
\hline Uttarakhand & 25,000 & 3,756 & NA & CEA (2016) \\
\hline Tripura & NA & 62 & 1,025 & CEA (2016) \\
\hline $\begin{array}{l}\text { West } \\
\text { Bengal }\end{array}$ & NA & 1,328 & 1,199 & CEA (2016) \\
\hline Nepal & 43,000 & 753 & 3,496 & $\begin{array}{l}2015 \text { (International Hydropower } \\
\text { Association website 2015) }\end{array}$ \\
\hline Myanmar & 100,000 & $3,151(2015)$ & 9,502 & $\begin{array}{l}2015 \text { (International Hydropower } \\
\text { Association website 2015) }\end{array}$ \\
\hline Pakistan & 50,000 & 6,902 & $33,946.5$ & WAPDA Annual Report 2013-14 \\
\hline
\end{tabular}

Sources For Col (2) and (3), as mentioned in the last Col (5), for Col (4), United Nations Statistics Division for 2015, available online at https:// unstats.un.org/unsd/energy/yearbook/2015/t32.pdf

(Box 8.5). For instance, Nepal has developed multiple mechanisms for sharing benefits with local communities. These include, among others implementations, a formal mechanism of royalty sharing and a unique Nepali home-grown solution of giving hydropower equity shares to local affected local populations (Shrestha et al. 2016). In India, on the other hand, several policies have institutionalized mechanisms of benefit sharing, but lack of implementation means that local communities often protest against these projects. Overall, hydropower can be a win-win development for the concerned region, provided that its negative externalities are managed. One particular area of concern is the irrigation-hydropower tradeoff. Not much is known about the extent to which farmer-managed irrigation systems are affected by hydropower projects, but there is some evidence that with proper planning and local participation, hydropower projects can offset some of the tradeoffs and provide additional irrigation benefits to local people. 


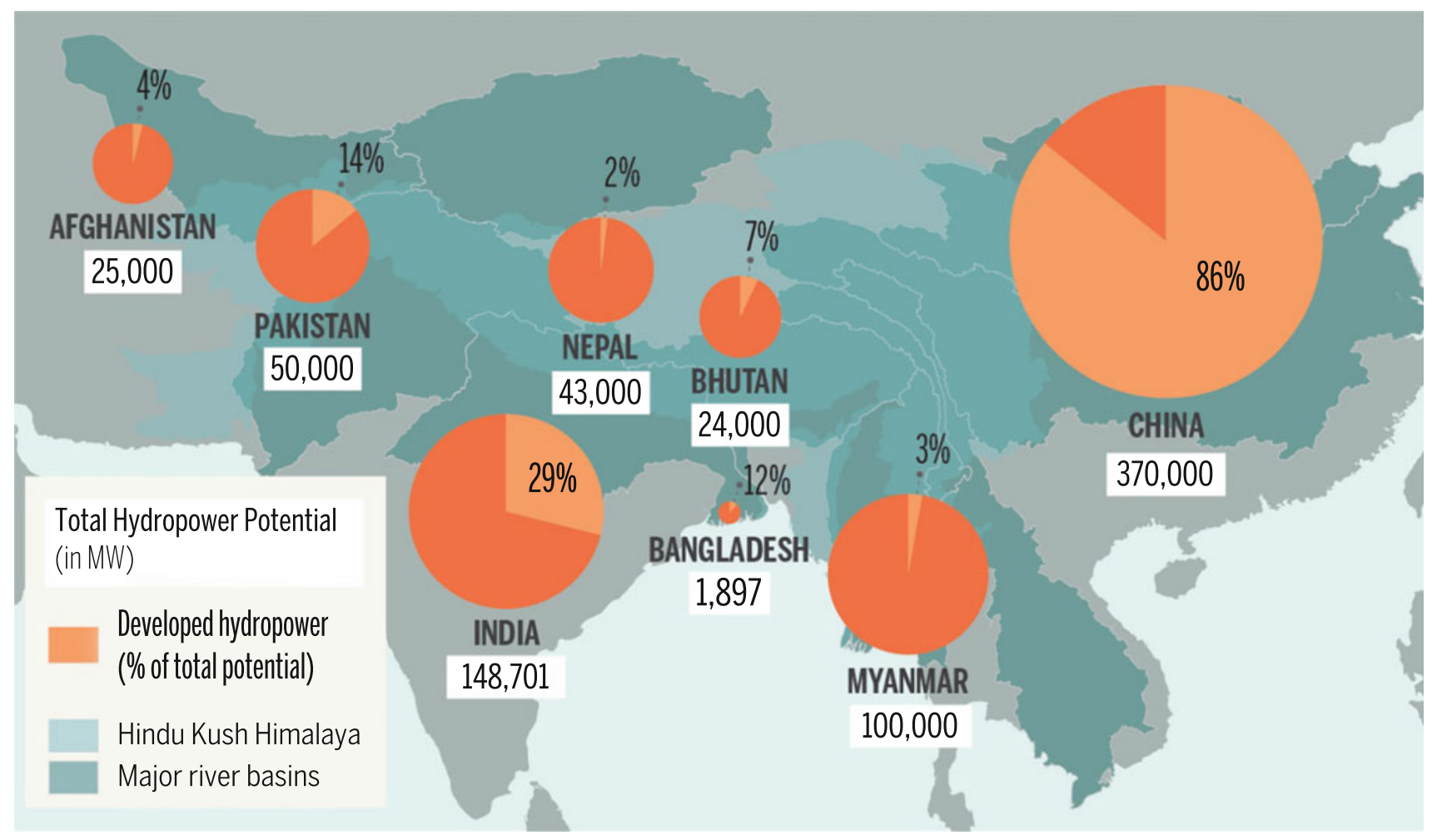

Fig. 8.9 Total hydropower potential and developed hydropower as a percentage of total by country (Sources See Table 8.5)

\section{Box 8.5 Water-related benefit sharing in hydro- power projects: examples from $\mathrm{Nepal}$}

Hydropower development leads to short-term and long-term changes in the hydrology of project-affected areas and often impinges on formal and informal water rights of local populations. Hydropower projects are required to mitigate losses to the local people or compensate for losses related to the reduction of flow in project-affected areas, which are either partially or completely dewatered.

In order to create benefits, hydropower developers invest in improving irrigation systems or fisheries and providing access to drinking water. Several hydropower projects support local farmers in the construction of check dams and irrigation canals and, in some cases, also support the regular maintenance of these facilities. Among these cases, Ridi and Aadhi Khola hydropower projects have been exemplary in showing how small hydropower projects can meet the energy and food-security demands of project-affected communities. The Kali Gandaki-A project recognized local fishing rights of the Bote indigenous fishing community, trained the community in new fishing technology, and provided access to government hatchery services. Many hydropower projects have provided drinking water to project-affected citizens as a benefit.
Water-supply lines provided by hydropower projects bring clean, reliable water closer to households, reducing the time needed to fetch it from distant sources-a change that has been especially beneficial to women.

\subsubsection{Water for Drinking and Sanitation}

The Millennium Development Goals (MDGs) set the target of reducing by half the proportion of people without access to safe drinking water and basic sanitation by 2015 . As seen in Table 8.6 and Fig. 8.10, most countries of the HKH have performed moderately well in terms of improving access to drinking water but have substantially lagged behind in achieving safe sanitation goals.

In 2015, the global community adopted the SDGs. Unlike the prior Millennium Development Goals (MDGs), which addressed water only in terms of water for sanitation and health, the SDG water-related goals are more comprehensive. Goal 6 focuses on water exclusively. Universal access to drinking water and sanitation correctly remain central, with even more focus needed on quality of service as opposed to just quantitative aspects. At the same time, other considerations are also important-water quality, 
Table 8.6 Drinking water and sanitation access in HKH countries

\begin{tabular}{l|l|l|l|l|l|l}
\hline \multirow{2}{*}{ Country } & \multicolumn{3}{|c|}{$\begin{array}{l}\text { Sanitation access } \\
\text { total population) }\end{array}$} & \multicolumn{3}{c}{$\begin{array}{l}\text { Drinking water access } \\
\text { (\% of total population) }\end{array}$} \\
\cline { 2 - 7 } & Total & Urban & Rural & Total & Urban & Rural \\
\hline Afghanistan & 37 & 60 & 30 & 50 & 78 & 42 \\
\hline Bangladesh & $\mathrm{NA}^{*}$ & 57 & 55 & 80 & 85 & 78 \\
\hline Bhutan & 65 & 87 & 54 & 92 & 99 & 88 \\
\hline China & $\mathrm{NA}^{*}$ & 58 & 52 & 89 & 98 & 82 \\
\hline India & 31 & 54 & 21 & 88 & 96 & 84 \\
\hline Myanmar & 81 & 86 & 79 & 71 & 75 & 69 \\
\hline Nepal & 62 & $\mathrm{NA}^{*}$ & $\mathrm{NA}^{*}$ & 88 & 93 & 87 \\
\hline Pakistan & 91 & $\mathrm{NA}^{*}$ & $\mathrm{NA}^{*}$ & 48 & $\mathrm{NA}^{*}$ & $\mathrm{NA}^{*}$
\end{tabular}

NA* not available

Source FAO (2011); WHO/UN-Water (2014)

wastewater management and reuse, transboundary cooperation, ecosystem services, and capacity building.

Burgeoning urban populations in the HKH will exert further stress on already overstretched urban services. As a result, standard solutions such as providing piped water and building more toilets will add only marginal benefits, unless the realities specific to mountain water resources are taken into account. For instance, tapping mountain springs will become increasingly difficult, given the widespread anecdotal as well as new emerging knowledge that documents drying up of springs (Poudel and Duex 2017; Kumar and Sen 2017a, b). New investments will be necessary for spring revival. ICIMOD and its partners have come up with a comprehensive 8-step methodology for the revival of mountain springs, and it is being tested in few sites in Nepal (Shrestha et al. 2017). This is important because springs are the only source of reliable water supply for large number of mountain communities and they do not get the attention they deserve. Most importantly, communities must be involved and have decision-making authority at all stages of water and sanitation services-from planning and construction to maintenance and management. However, it is important to keep in mind that community itself is a heterogeneous entity, and some members are subject to discrimination due their gender, caste or ethnicity. A study by Coffey et al. (2015) shows that the problem of open defecation in plains of India is deeply related to caste prejudices, whereas in parts of India where caste system is not prevalent (e.g. northeastern states), level of sanitation is much higher than the rest of India (Ghosh and Cairncross 2014).

\subsubsection{Urban Water}

Following the global trend, all countries in the HKH are urbanizing rapidly. This means, existing urban centers will
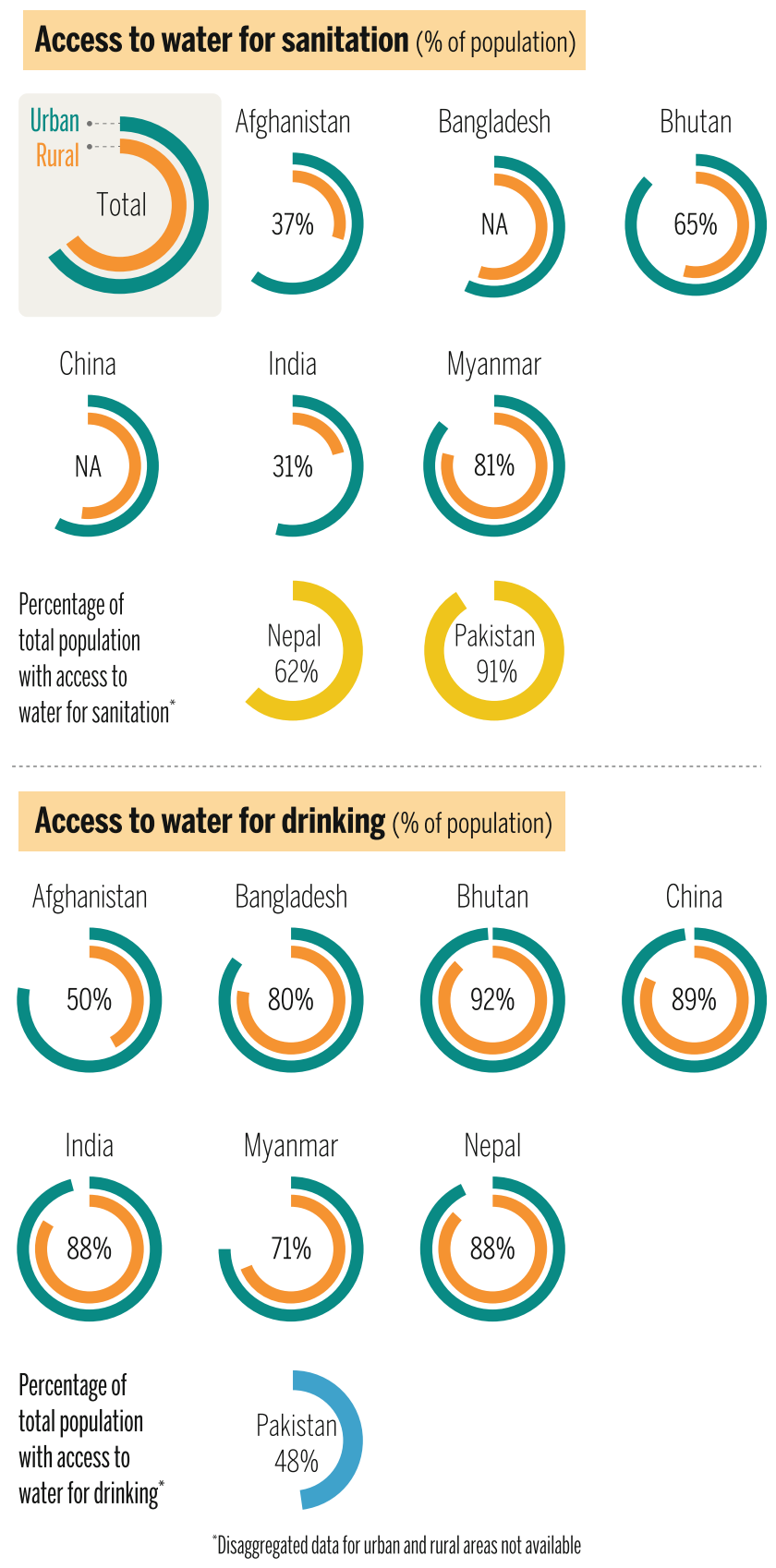

Fig. 8.10 Access to water for sanitation and drinking by country (Source FAO 2011; WHO/UN-Water 2014)

expand and new urban centers will emerge. Trends of urbanization are somewhat different in each of the $\mathrm{HKH}$ countries. In the Pakistan portion of the HKH, the rate of urbanization has been low due to the constraints placed by the terrain and lack of economic opportunities. The urban population in the northern region of Pakistan is less than $20 \%$.

In the Indian Himalayas, the rate of urbanization has been low in the higher altitudes, but it has been more rapid in the foothills (also called the Siwaliks). In western Indian 
Table 8.7 Gap between municipal water supply and demand in selected cities of the HKH countries of Nepal, India, Bhutan, and Afghanistan

\begin{tabular}{|c|c|c|c|c|c|c|c|c|}
\hline \multirow[t]{2}{*}{ City, country } & \multirow[t]{2}{*}{$\begin{array}{l}\text { Average } \\
\text { elevation (masl) }\end{array}$} & \multirow[t]{2}{*}{ Population (year) } & \multicolumn{2}{|c|}{$\begin{array}{l}\text { Supply (million } \\
\text { liters per day } \\
\text { MLD) }\end{array}$} & \multirow[t]{2}{*}{$\begin{array}{l}\text { Demand } \\
\text { (MLD) }\end{array}$} & \multicolumn{2}{|c|}{ Demand met (\%) } & \multirow[t]{2}{*}{$\begin{array}{l}\text { Year of available water } \\
\text { supply/demand data }\end{array}$} \\
\hline & & & $\begin{array}{l}\text { Wet } \\
\text { season }\end{array}$ & $\begin{array}{l}\text { Dry } \\
\text { season }\end{array}$ & & $\begin{array}{l}\text { Wet } \\
\text { season }\end{array}$ & $\begin{array}{l}\text { Dry } \\
\text { season }\end{array}$ & \\
\hline $\begin{array}{l}\text { Kathmandu, } \\
\text { Nepal }\end{array}$ & 1350 & $2,510,000(2012)$ & 105 & 86 & 280 & 37.5 & 30.7 & 2012 \\
\hline Pokhara, Nepal & 884 & $300,000(2012)$ & 24 & 21 & 45 & 53.3 & 46.7 & 2014 \\
\hline Darjeeling, India & 2045 & $132,016(2011)$ & 8.3 & 2.3 & 8.6 & 96.5 & 26.7 & 2002 \\
\hline Mussoorie, India & 2005 & $30,118(2011)$ & \multicolumn{2}{|l|}{7.67} & 14.4 & \multicolumn{2}{|l|}{53.3} & 2014 \\
\hline Shimla, India & 2205 & $171,817(2011)$ & \multicolumn{2}{|l|}{54.5} & 64.7 & \multicolumn{2}{|l|}{84.2} & 2012 \\
\hline Thimphu, Bhutan & 2320 & 79,185 (2005) & \multicolumn{2}{|l|}{$\mathrm{NA}^{*}$} & 9.9 & \multicolumn{2}{|l|}{$\mathrm{NA}^{*}$} & 2006 \\
\hline $\begin{array}{l}\text { Kabul, } \\
\text { Afganisthan }\end{array}$ & 1791 & $3,476,000(2013)$ & \multicolumn{2}{|l|}{52.14} & $\mathrm{NA}^{*}$ & \multicolumn{2}{|l|}{$\mathrm{NA}^{*}$} & 2013 \\
\hline
\end{tabular}

NA* not available. Source City population data from National Population Censuses of respective countries, while municipal water supply and demand statistics have been compiled from various newspaper reports reliable because formal data from municipalities and/or countries/states are not available in the public domain. Darjeeling: TOI (2014); Mussoorie: Pioneer (2013); Shimla: TOI (2013); Thimpu: The Bhutanese (2014); Kabul: The Guardian (2010); Kathmandu and Pokhara: Republica (2014). For Shimla and Mussorie, supply and demand data is aggregated across seasons

Himalaya, Srinagar is the largest urban center, while in the eastern Himalaya, the urban centers of Gangtok, Kalimpong, and Darjeeling have been growing at a very rapid pace. Nepal remains one of the least urbanized countries in South Asia - and also in the world. There are considerable problems in terms of definition in the study of Nepal's urbanization, since the areas designated "urban" have been defined and redefined over the years with evident lack of consistency. In Nepal, Kathmandu is by far the largest urban agglomeration.

Bangladesh occupies a very small section of the Himalayas, represented by the Chittagong Hill Tracts (CHT). In these areas, tourism has flourished and led to the growth of a few small urban centers, namely Rangamati, Bandarban, and Khagrachari. Much of the urbanization in the region has been unplanned and haphazard, leading to serious problems related to water and sanitation.

The fact that mountain towns and cities are also tourist destinations amounts to additional pressure on water resources, and the water needs of the local population often are not met in pursuit of serving the water requirements of tourists. This sometimes leads to social conflicts. Table 8.7 shows that almost no major city in the region is self-sufficient in terms of municipal water supply.

Almost all urban centers suffer from water shortage. Many of these urban centres are hill stations set up by the colonial British government on ridgetops, while water sources are deep down in the valleys. Compounding the problem of water shortage are issues such as neglect of traditional water systems like stone spouts and springs (Molden et al. 2016; Colopy 2012), outdated and poorly constructed water distribution systems that get superimposed on traditional water systems, pipe leakages, and poor governance that puts primacy on piped water supply over other time tested and sustainable sources. Different cities have adopted different coping mechanisms. In Kathmandu and Darjeeling, private water tankers provide water to millions of residents, while in Bhutan, water supply is rationed and people are encouraged to manage their own demand accordingly. In Kathmandu, wastewater generated by city sewage is used to irrigate vegetable crops in peri-urban parts of the valley (Box 8.6).

Water shortages in the urban centers of HKH affect men, women, and marginalized communities differently. In Kathmandu Valley, the poor who live in marginal areas within the city, especially in the peri-urban areas outside the municipal water supply limits, pay a higher price for buying water from informal sources (Raina 2016). The same is true for residents who rent accommodation even in core city centre - they often do not have guaranteed rights to use the municipal connection, which is reserved for the house owner, and end up paying more than double for water (Molden et al. 2016). At the same time, in many Himalayan towns like Kathmandu, urban water security is also closely linked with cultural practice. For example, stone spouts which originate in springs, are seen as a form "of cultural resilience, where people interact with water infrastructure in ways that extend beyond utilitarian concerns" (Molden et al. 2016). This is true for many other urban centres in the Himalayas where traditional water supply systems embedded in local cultural beliefs have been neglected in favor of western patterns of piped water supply. Long term sustainability in urban water in the HKH will require a strategic management of government-sponsored, "modern" piped 
water systems along with preservation of traditional water systems, particularly in ways that are mindful of gender and class differences in water access, provisioning, and security.

\section{Box 8.6 Wastewater use in Kathmandu Valley}

In 2011, Kathmandu had a population of 2.51 million and it has been growing at a rate of $6.6 \%$ per year-the fastest urban growth in all of Nepal. It is estimated that a total of 93 million litres per day (MLD) of wastewater is generated from the domestic sector and another 6.5 MLD from the industrial sector. These numbers are growing by the day, but wastewater management facilities have not expanded commensurately. Of the total wastewater generated in the valley, less than $50 \%$ is actually collected and treated; the rest is disposed of directly into the rivers.

Wastewater is used extensively for irrigation in the urban and peri-urban parts of the valley. At least one third of the cultivated area in the Valley is irrigated using wastewater, and almost two thirds of this wastewater is used directly in the fields without any kind of treatment (Bastakoti et al. 2014). A majority of the farmers reported using wastewater because there is no source of freshwater for irrigation and also because accessing this wastewater, often used illegally, is free of cost, unlike groundwater, which requires investment in tube wells and diesel pumps. This wastewater also happens to be nutrient-rich, and therefore reduces fertilizer costs. Farmers using this water for irrigation often complain of health issues, such as skin infections, and the indirect health impacts of these pollutants through the consumption of these vegetables and other crops are not trivial.

While it is recognized that negative health and environment impacts of waste use are significant, it is unlikely that policies or infrastructure to deal with the use of wastewater in agriculture will be developed anytime soon. In this context, it is important to also understand the positive contribution of wastewater to the Valley's agricultural economy, while framing adequate policies and institutions to manage the health risks of untreated-wastewater use.

\subsubsection{Water Quality: Major Biological and Chemical Contaminants Linked to Urbanization}

Due to unsustainable urbanization, industrialization, water abstraction, and agricultural intensification, deterioration of water quality is increasingly becoming a recognized concern in many parts of the HKH (Merz et al. 2003; Mateo-Sagasta and Tare 2016). Water quality degradation has significant impacts on human health and ecosystems and is limiting regional development (Mateo-Sagasta and Tare 2016). Approximately $20 \%$ of all deaths among children under five years of age is caused by water-borne diseases (WHO 2006). The water quality challenges are not homogeneous along the river systems and vary between upstream segments in the mountain regions and further downstream segments in the hills and plains (IITC 2010). In the upper segments, the rivers and streams flow on steep and narrow rocky beds, carry cold water, and are subjected to much less anthropogenic pollution. But they also have highly sensitive ecosystems and biodiversity. The lower segments of the river systems, on the other hand, are greatly modified by human interventions in terms of water diversion/abstraction, and they are subjected to a high degree of pollutant loads (IITC 2010; Shah and Shah 2013).

There are no comprehensive studies addressing water quality for the $\mathrm{HKH}$ as a whole. However, there have been some studies comparing two or three countries, including the study by Karn and Harada (2001), which looked at surface-water pollution in Kathmandu (Nepal), Delhi (India), and Dhaka (Bangladesh). This study revealed widespread pollution of water resources in all three cities through the presence of organic and pathogenic contaminants, heavy metals, and pesticides (Karn and Harada 2001). For example, in a $13 \mathrm{~km}$ stretch in the Bagmati River in the Kathmandu Valley, biochemical oxygen demand (BOD) increased from 3.8 to $30 \mathrm{mg} / \mathrm{L}$ moving downstream during 1992-1995. Similarly, BOD in the Yamuna River in Delhi, showed an increase from 1.3 to $17 \mathrm{mg} / \mathrm{L}$ in the downstream area (Karn and Harada 2001). Similar situations were found in all of the rivers close to Dhaka (Turag, Buriganga, and Dhaleswori).

Studies have estimated that municipal sewage contributed nearly $85 \%$ of all river pollution. This was due to two major factors: first, the unrestricted discharge of raw or partially treated wastewater (of both domestic and industrial origin); and second, the lack of adequate regulatory pollution-control measures and their strict enforcement in real practice (Karn and Harada 2001). The main Ganges stream in India still directly receives at least 2.7 billion $\mathrm{m}^{3}$ of sewage from medium and big cities every day, of which at least $74 \%$ is untreated (Mateo-Sagasta and Tare 2016). Additionally, the number of towns and cities that discharge their untreated wastewater to the tributaries of Ganges, and not only to the main stream, is substantially bigger. The Indian Central Pollution Control Board (CPCB) has identified 138 drains discharging 6 billion liters per day of polluted water into the Ganges (CPCB 2013; Mateo-Sagasta and Tare 2016).

Another issue is the lack of septage management systems. While there is growing interest in septage management, 
adequate treatment of septage does not currently exist in the region. Dumping of domestic solid wastes-including plastics, glass, and organic waste-also affects the river water quality. The collection capacity of municipal solid waste is limited and the treatment capacity is almost nil (Mateo-Sagasta and Tare 2016).

Industries contributed $14-17 \%$ of this river pollution, with pollutants coming from power plants, food-processing, breweries and distilleries, tanneries, as well as the industrial production of fertilizer, insecticides, textiles, carpets, vegetable oil, dairy, pharmaceuticals, and other chemicals (Karn and Harada 2001). The findings of another study suggested that the countries of the Ganges-Brahmaputra-Meghna River Basin are increasing their industrial activities, with approximately $70 \%$ of 300-500 million tons of heavy metals, solvents, toxic sludge, and other wastes being discharged untreated into the waterways (Babel and Wahid 2009).

The contribution of non-point source pollution (NPS) from agricultural areas in the HKH region has so far not been documented. Thus, the extent of their contribution to the pollution load is unclear. There are no regionwide comprehensive assessments of non-point source pollution from agriculture. There are some studies which claim that agrochemicals are a key polluter in the rivers (e.g., Gosh, ND), and there are others that believe that it is not a significant source of pollution (e.g., Trivedi 2010). Nevertheless, the observed trends in terms of expansion and intensification of the agricultural sector-including the sharp increase in fertilizer and pesticides use, and the booming development of livestock farms - point to an increasing trend in NPS contribution to degrading water quality (Mateo-Sagasta and Taare 2016).

In terms of groundwater pollution, the urban areas of Kathmandu mostly suffer from infiltration of urban storm water, leakage of wastewaters and septic tanks, and unregulated industrial activities. These wastewaters and septic-system effluent contain high concentrations of dissolved organic carbon, ammonia, pathogens, and organic micro-pollutants, as well as heavy metals and trace elements (Pant 2011). The presence of heavy metals in groundwater in the Swat River was found to vary along different stretches and was attributed to geology, corrosion of plumbing systems, and agricultural and industrial activities (Khan et al. 2013). In this study, the concentration of heavy metals in the groundwater was higher than in surface waters (Khan et al. 2013).

Some studies have also looked at biological pollutants. In groundwater in Kathmandu, maximum coliforms were found in the samples from shallow wells at $267 \mathrm{CFU} / 100 \mathrm{~mL}$, while the levels in tube and deep-tube wells were 129 and $149 \mathrm{CFU} / 100 \mathrm{~mL}$ respectively. The coliforms detected in shallow wells may be due to poor drainage, the improper construction of septic tanks close to groundwater sources, and the direct discharge of untreated sewage into surface waters (Pant 2011) — all of which further reflect the lack of planning and investment in the region's water infrastructure. Similar results were reported from Rawalpindi, in Pakistan, where Sehar et al. (2011) found municipal water containing fecal coliforms due to leakage of sewage into water supply pipelines. In Srinagar, in India, significant land use changes since the early 1980s have led to pollution of the freshwater Dal Lake, due the discharge of various nutrients and pollutants (Amin et al. 2014).

In some parts of the HKH, such as Afghanistan, infrastructure has been damaged or destroyed by years of war. Only $27 \%$ of Afghanistan's population has access to improved water sources, and only $20 \%$ have access in rural areas-marking the lowest percentage in the world. While the number of households in urban areas with access to municipal water is growing (35\% in the capital city, Kabul), the system for solid-waste collection is limited, with about $70 \%$ of the city's solid waste accumulating on roadsides and in drains, rivers, and open spaces - where they pose a significant environmental hazard. In addition, most sewage is disposed of in domestic drainage pits and shallow, open sewage channels that run along the streets, thereby threatening shallow aquifers with pollution from biological and chemical contaminants. A study on heavy metal and microbial loads in sewage-irrigated vegetables in Kabul revealed lead loads and pathogenic contamination higher than the threshold levels (Safi and Buerkert 2011). Considering the high incidences of intestinal diseases and diarrhea, Safi and Buerkert (2011) recommended further detailed surveys and improvements to Kabul's sewage infrastructure to eliminate potential health risks.

\section{Box 8.7 Arsenic in groundwater and its implica- tions for agriculture}

Arsenic in groundwater is a significant threat in the lower parts of the Ganges, Brahmaputra, and Mekong basins. In recent years, a growing body of literature has emerged that examines the impact of irrigation with arsenic-rich water on crop production and productivity and looks at the effectiveness of arsenic remediation in agricultural context. A systematic review of 29 high-quality studies (Senanayake and Mukherji 2014) showed no clear relationship between arsenic content in irrigation water-or in soil with arsenic uptake by paddy grains - and crop production. However, there is a near consensus that prolonged cultivation with arsenic-rich water leads to decline in paddy productivity.

The review of literature also shows that there are six broad categories of intervention that can reduce arsenic uptake by crops or prevent its entry into the human food 
chain. These are: deficit irrigation, soil fertilization, growing alternative field crops (other than paddy), switching to arsenic-tolerant paddy cultivars, reducing arsenic content in rice through cooking methods, and nutritional supplements. Results from these studies show that all of these interventions are successful in preventing excessive arsenic from entering the human food chain, but these practices have yet to be incorporated into mainstream extension activities.

\subsubsection{Water Infrastructure}

Water storage infrastructure and enhanced management of excess monsoon water would help HKH countries to better meet water requirements during the dry season and to also cope with water scarcity issues. Traditionally, mountain people have found ways to store water by building ponds, terracing fields, harvesting rainwater, and employing small-scale irrigation systems (Molden et al. 2014). Water is also often diverted from mountain springs, which are fed by groundwater and therefore a more reliable source during dry seasons. These methods are still practiced throughout much of the HKH middle hills. However, with increasing demand for agricultural and energy production, the demand for better and larger infrastructure is also increasing.

This has led to construction of various irrigation structures in the region. In Pakistan, two large storage dams situated in the upper Indus basin, Tarbela dam on the Indus, and Mangla dam on the Jhelum now regulate the irrigation system that millions of people downstream rely on. In India alone, there are 4858 completed large dams (and 313 are under construction, of which nearly 100 are located in the mountainous states) (CWC 2014). Most of the rivers in Nepal have little storage compared to the monsoon run-off in the rivers (Bandyopadhyay 2009). Feasibility studies for many large multi-purpose projects with storage have been proposed, but development has been slow, mainly due to lack of common interest and agreement between Nepal and India.

Even in countries like China, India and Pakistan, storage is still quite low, despite the development of extensive irrigation infrastructures. For example, the current storage capacity in the Ganges in large infrastructure is only $10 \%$ of total average annual flow. In Nepal, FMIS have, for centuries, been developed and managed by local farmers themselves. Extensive embankment infrastructure has also been built on riverbanks to control floods during the rainy season. In India, about $34,000 \mathrm{~km}$ of flood embankments have been constructed, largely in North and Northeast India (Mazumder 2011).
Water-related infrastructure can intensify upstream-downstream linkages, providing benefits and risks to both areas. Structures like dams and reservoirs can store water during flood periods, which can: (a) be available during the dry season through open channels or pipelines for irrigation and other consumptive, recreational, or environmental uses for ecosystem services; (b) produce electricity; and (c) improve navigation. However, these structures come at a high cost to local communities displaced by them as they are forced to relocate and adjust to shifting resources and cultures.

Dams and reservoirs can also be problematic as they can block and store sediment that is transported in river flow. Fine silt and eroded materials are considered beneficial to plains farming; therefore, the blockage of sediment in natural flow can affect agriculture production. Singh (1990) has evaluated the Farakka barrage, determining that it has negatively affected the downstream region of Bangladesh by reducing silt flow, thereby reducing soil fertility, and by increasing the ingress of saltwater up the river. The Brahmaputra leaves behind immense sand deposits in Dhemaji and Lakhimpur districts of Assam, while the Koshi floods in 2008 rendered a large area of fertile lands infertile due to sand deposition. Silt transport in rivers also leads to filling up and reduction of the storage capacity of reservoirs, lakes, and ponds as well as the carrying capacity of canals. The Teesta Barrage in Bangladesh had a provision of a silting tank in the main canal system in order to stop the entry of silt into canals and therefore to the agriculture fields.

In the Indus River Basin, downstream discharge to the sea has decreased significantly due to construction of vast networks of irrigation canals, barrages, and associated structures. Laghari et al. (2015) estimated that these anthropogenic changes have resulted in five times less sediment in downstream areas. Tahmiscioğlu and Anul (2007) highlighted that dam construction and the resulting holding of sediment can lead to changes in the natural water regime, including the composition of soil nutrients downstream.

In Nepal, excessive river sediment has affected most of the power plants in the Himalayas through build-up in reservoirs or by erosion of turbine components, reducing the life of the plants. Al-Faraj and Scholz (2014) highlighted that human-made structures, such as dams and large-scale water systems also decrease water availability in downstream areas of transboundary river basins.

Water storage infrastructure can also include natural structures such as lakes, ponds, groundwater, and soil moisture. Managing natural storage systems are more cost effective and sustainable. Management and enhancement of natural storage systems still need to be explored and if possible, included with the feasibility studies on built infrastructure projects such as large dams. 


\subsubsection{Ecosystem Processes and Environmental Flows}

With the growing degree of human intervention in the rivers of the $\mathrm{HKH}$, concerns have emerged over the future of the aquatic ecosystems in the $\mathrm{HKH}$ and continuation of the related ecosystem processes (as has been detailed in Chap. 6). Increasing energy and water demands from the domestic, agricultural, industrial, and commercial sectors are leading to plans for greater exploitation of these rivers.

There are considerable, though poorly understood, implications of climate change on increasing monsoon-season flows and decreasing dry-season flowsparticularly coupled with various anthropogenic interventions. The term "environmental flows" (EFs) is now commonly used to refer to a managed flow regime designed to maintain a river in some agreed-upon, non-pristine ecological condition as to make room for the human interventions. Each component of the natural hydrological regime has a certain ecological role to perform. In regulated basins, the magnitude, timing, frequency, and duration of some or all flow components can end up getting modified. A tradeoff has to be arrived at through negotiations among all stakeholders in order to identify the instream flow regime that would support the aquatic ecosystem processes and services in a sub-pristine state. The suite of acceptable flow patterns can ensure a flow regime capable of sustaining target aquatic ecosystem processes and services in a sub-pristine state (Poff et al. 1997; Arthington et al. 2006). EFs can therefore be seen as a way to balance human interventions and the maintenance of river ecology at acceptable levels of degradation.

The knowledge base for operationalizing EF practice is not yet well established in any of the HKH countries, but it is emerging. There has been a particularly significant increase in interest on the matter in China and India (Bandyopadhyay 2017). In the last decade, India has taken a rather mechanical - and not empirically tested - approach for the assessment of EFs, and the government is trying to implement an EF plan under the Ganges rejuvenation program. However, demand for a scientifically tested approach for arriving at an acceptable balance between interventions and EFs is growing. In Nepal, Bhutan, Pakistan, and Bangladesh, EF is beginning to enter discussions on river basin governance. With limited water resource development and with most infrastructure development still in the planning phase (especially in the upper mountain regions), there is still a chance to set up measurement of $\mathrm{EF}$ requirements for ecosystem processes and put appropriate policies in place before these rivers are seriously degraded.

Despite the extensive study of environmental water allocations in countries such as the UK, Australia, USA, and
South Africa, arriving at managed flow regimes acceptable to all stakeholders in the basin continues to be elusive. In India, the Krishna Water Disputes Tribunal in 2010 had considered the delicate and much awaited issue of $\mathrm{EF}$ in a river and implemented it in the Krishna River and its basin area. It awarded separate waters to the river itself in its different reaches, making it incumbent upon the concerned states to make available and maintain the recommended quantities of water in-stream round the year as prescribed by the Tribunal (MoWR 2010). For that purpose, it replaced the EF with Minimum Flows, which incorporates small needs of those who live by the river and whose livelihood depend on that river. It also accounts for the religious need in addition to the EF need. At present, EF are most often justified by ecological concerns - for instance, by the question of preserving ecosystem health for the sake of biodiversity conservation. This approach pays little regard to those whose livelihoods are gained directly from the continuity of ecosystem services of the rivers. For many rural men and women in developing countries, aquatic ecosystems are essential to their wellbeing and livelihood, providing domestic water and also sustaining fisheries, livestock, grazing, and other important resources. Further, as a rule, current EF considerations do not take into account cultural and religious contexts, which are also very important in the HKH. Therefore, there is a need to further develop methodologies for assessing of EFs for the HKH and to explore ways to incorporate consideration of EFs into river-governance practices.

\subsection{Water Governance in the Hindu Kush Himalaya}

While the previous sections have addressed the physical availability and the uses of water in the $\mathrm{HKH}$, this section will highlight how challenges of governance-as distinct from water scarcity per se-form a crucially important obstacle to achieving water security in the region Biggs et al. (2013a).

As suggested in earlier sections, water scarcity is institutionally mediated across geographical scales within the region. By characterizing the formal, informal, and hybrid water-governance institutions at the local/micro, subnational/national/meso, and regional/international/macro scales, a scalar lens of governance will inform our discussion of HKH water security. The links that connect water security to energy and food security-known as the water-energy-food (WEF) nexus - will also be highlighted. In a critical mode, we question conventional wisdom on the existence of the nexus at the micro scale within the HKH. Scaling up to meso and macro levels, we then critically 
examine prospective approaches to both basin-scale management within the region and to management of transboundary water relations at the subnational and national scales. We conclude this section with a consideration of pathways toward improved water-related decision-making in the HKH, across micro, meso, and macro scales.

For the purpose of this discussion, water governance is understood to be the mechanism for addressing questions of water access, use, and distribution among social actors, sectors, and across geographical scales. The outcome of good water governance should be social equity and political stability enabled by environmental quality across the HKH. A key premise of our discussion is that water governance is a deeply political enterprise. If water is life, and human life is steeped in politics, then water use and distribution are inevitably steeped in politics as well. This section is organized around geographical scales, not only to illustrate how politics impact water governance at the micro, meso, and macro scales, but also how water politics might be moderated and informed by evidence-based policy.

\subsubsection{Characterization of Existing Water Governance Institutions}

The HKH is characterized by relatively weak penetration of formal state (national) institutions. This is due to the remoteness of much of the region, owing mainly to topography. Issues over water are no exception to this general lack of strong state presence, although modern state institutions have recently started becoming more influential, especially in terms of infrastructure development at the meso and macro scales. Informal customary water governance at the micro-scale, with its marked gender and other inequalities, has been the predominant institutional norm in the region. The recent rise in state penetration has not replaced existing governance mechanisms, but it has spawned hybrid governance regimes with informal structures heavily mediating state intervention, rather than the reverse. The state has, however, indirectly contributed to profound transformation of informal water governance through the provision of energy and technology for harnessing and managing water supply as well as through investments in infrastructure for irrigation and energy (particularly hydropower).

The region's political geography is dominated by nation-states, which must be the arbiters of any water governance at the country level. At the moment, there are just a few examples of multilateral or regional water-governance structures, e.g., Indus River Commission (and Indus Waters Treaty) and Mekong River Commission for the lower Mekong basin. Two regional multilateral institutions-
South Asian Association for Regional Cooperation (SAARC) and the International Centre for Integrated Mountain Development (ICIMOD) - have not been involved in water governance. While comprehensive review of SAARC is beyond the scope of this chapter, suffice it to say that SAARC has maintained a strict neutrality and a studied silence on the subject. On the other hand, ICIMOD has been quite proactive in generating knowledge on water governance and related issues in the region, but it has limited its activities to research and dissemination. This lack of a multilateral or regional governance framework for water is largely a result of the nationalization of water by the HKH countries, as the power disparities among these countries cause them to guard individual sovereignty over water.

Sovereign control over water has not prevented some countries in the region from entering bilateral treaties, which require regulating the exercise of sovereignty over domestic water resources to satisfy treaty obligations. Such treaties and their accompanying institutional structures are discussed in Sect. 8.3.2.

At the subnational scale, Shah (2009) describes the existing water management structures in northern Afghanistan as community-based water-management systems that pivot around the institution of an elected or selected mir-e$a a b$ (water master) with minimal or absent state presence in managing most canal and karez systems (underground aqueduct, also known as qanat in west Asia). Local water-allocation systems were largely disrupted during the long Afghan civil war, and the inability of the post-Taliban regime to restore to original claimants their abandoned or appropriated water rights is a source of considerable resentment among the Afghan populace.

Since 2003, through the Ministry of Rural Rehabilitation and Development, the Afghan government has inserted itself into local-level water management by availing funds for participatory water-infrastructure development through Community Development Councils operating under the National Solidarity Programme. This has led to more of a hybrid institutional regime, with the balance of power resting with the local informal regime more than the state. Due to the contours of local power relations, the results of these hybrid management systems have not been equitable in all cases in terms of gender or class (McCarthy and Mustafa 2014).

In the Pakistani-administered part of the Karakoram range, constituting Gilgit-Baltistan, water-management institutions have also been largely local and community-based - and they have gotten a considerable boost from the investments in community organization and water-infrastructure development undertaken by the Aga Khan Rural Support Programme (AKRSP) and similar NGOs (Box 8.8). 


\section{Box 8.8 Aga Khan rural support programme}

AKRSP provides an illustrative evidence of a productive and cooperative relationship between state and non-state (or more informal) actors. The AKRSP's primary approach is to promote the participation of local stakeholders in water management through the creation and support of village organizations, which then provide the structure and resources necessary for these villages to effectively manage their own water supplies. This model has enjoyed some success in promoting water access, particularly in more rural and difficult-to-access areas. One of the biggest successes of the program, however, has been its relatively extensive engagement with state authorities, providing logistical, financial, and technical resources in support of these activities (De Spoelberch 1987; Ehsan-ul-Haq 2007). This example illustrates the potential for greater state cooperation with a variety of actors in promoting effective and sustainable water-management activities.

Gilgit-Baltistan might be an exception in the $\mathrm{HKH}$, as it demonstrates synergy and cooperation between state and non-state actors, including the AKRSP, Aga Khan Foundation (AKF), and other related institutions. By contrast, in most of the $\mathrm{HKH}$, typical relations between state and non-state water managers are indifferent, if not downright hostile. In Pakistan, as in India, water is primarily a provincial/state subject, with the central governments only intervening in the financing of large-scale infrastructure projects, such as hydropower, deemed to be of national interest. However, within the HKH areas of both countries, water management, for all practical purposes, remains local and community-based.

Many of these local-scale water-management systems limit access to safe water by gender, causing serious consequences for women and the health and wellbeing of girls. In Nepal, Udas and Zwarteveen (2010) documented that the central irrigation bureaucracy is unable to systematically address issues of gendered access to water because of the country's entrenched patriarchal ethos, confirming the earlier review by Chandra and Fawcett (1999), who documented how lack of participation by women in water-supply projects ultimately increased their workloads and diminished their prospects of benefiting from improved water infrastructure.

In the Indian Himalayas, the central government's Ministry of Water Resources, River Development \& Ganga Rejuvenation, and Central Water Commission play strong, engineering-focused, state-led roles in the development of water resources, investment in infrastructure, and data collection and monitoring, with primary influence at the macro scale. Without adequate attention to meso and macro scales, national involvement may tend to overlook local water management, extraction, and allocation practices-especially in the case of FMIS, which have a centuries-long tradition and form the backbone of livelihoods and food-security in rural mountain communities. Additionally, globalization, market integration, the penetration of contract farming, and seasonal to permanent out-migration (especially of working-age males) are having profound impacts on irrigated agriculture.

Within the region, Himachal Pradesh and Sikkim present more dynamic and transformative instances of active state involvement in water management - ranging from irrigation and potable-water supply to hydropower. By contrast, the states of Jammu and Kashmir and Uttarakhand have resorted to a more conventional approach, with central government making a strong imprint on infrastructure and water management. This is due, in part, to territorial and strategic concerns. In J\&K, concerns ostensibly include the integration of local communities into mainstream Indian polity; in Uttarakhand, there are governmental concerns over nationalist sentiments for Mother Ganga and for the historical marginalization of hill districts, which formed part of Uttar Pradesh state before breaking off as the new state of Uttarakhand (previously Uttaranchal).

The states of Northeast India present an entirely different picture, with local practices and traditions holding sway, marking a governance system that is less of a hybrid than one in which state and central government institutions are largely absent. With the advent of hydropower in the Northeast - and the perception of a large gap between generation potential and installed capacity on high-volume tributaries to the Brahmaputra - the region is witnessing greater involvement of central government, including investments in infrastructure through public and private capital, as well by multilateral institutions like the Asian Development Bank.

In terms of domestic water supply, the expanding urban areas of the HKH are largely serviced by either centrally or provincially controlled agencies (such as the centrally controlled Kathmandu Valley Water and Sanitation Board). In HKH rural areas, the main government agency responsible for domestic water supply is Public Health Engineering (PHE). Most of the time, however, the domestic water supply is actually serviced through community-based initiatives. PHE has an infrastructure bent and often assumes responsibility for supplying domestic water to larger and medium sized cities in the region, such as Gilgit, Muzaffarabad, and Srinagar.

In all of the urban water-supply situations, the emphasis is on networked, piped water systems, replicating the infrastructure and institutional models of the western and plains cities of South Asia - but without regard to topography, cultural particularities, or the institutional history of 
water supply in HKH cities. The consequences go beyond an uneven water supply, inequitably rendered in terms of class and location across the urban areas of the HKH; serious health hazards also arise from water-supply contamination.

In sum, the key features of the institutional water landscape in the $\mathrm{HKH}$ are as follows:

- Water management is characterized by a hybrid formal-informal regime, with the balance of power in favor of informal institutions, particularly at the local level.

- At the macro scale-and certainly for meso- and macro-scale infrastructural development - the balance of power is in favor of formal state institutions.

- There is a disconnect between the macro/national, meso/regional, and micro/local water-governance institutions, which is largely a function of the political marginality of national terrain within the HKH. This is especially true of larger nation-states. Nepal and Bhutan are the exceptions, with their national boundaries falling predominantly within the HKH.

- There is a need for greater synergy between state and informal water-management institutions without the strict institutional boundaries that exist at present. Local water management and its informal institutions could benefit from state support instead of the antagonism that is present today.

- The gender inequities often witnessed in informal and formal institutions are a matter of serious concern and should be a priority area for reform.

- The urban water-supply systems in emerging cities in the HKH need to be more attuned to the particularities of the topography and the organic growth of the cities where formal institutional regimes uncomfortably preside over the informal institutional landscape, with deleterious consequences for water quality and quantity.

These characteristics of local and national water institutions exist in juxtaposition to governance at the level of transboundary river basins; thus, we turn to conflict and cooperation across geographical scales in the HKH.

\subsubsection{River-Basin Approaches and Transboundary Conflict and Cooperation}

Countries throughout the HKH face similar challenges of increasing water demand due to economic growth. Availability of and access to water resources vary dramatically throughout the region due to seasonal precipitation patterns, the geographic distribution of glaciers, and, importantly, a lack of adequate governance. In addition, rising uncertainty in water availability and increases in extreme weather are both likely due to climate change (Molden et al. 2014). Management of water resources at a river-basin scale may help in maximizing benefits of infrastructure projects, negotiating competing water and energy uses, and minimizing risk of water-related hazards. However, a river-basin approach is challenging at macro (or meso) scales that are either international or interstate (subnational).

At both transboundary and subnational levels, coordination throughout shared river basins requires increased institutional capacity, particularly across scales, and may require a decoupling of national political aims from shared resource-management objectives. The river-basin approach is particularly relevant in the context of upstream-downstream benefit sharing between $\mathrm{HKH}$ areas and downstream populations in the plains. Within the $\mathrm{HKH}$, however, much of the demand for water, especially for drinking water, is met by groundwater from springs and handpumps - and tubewells in urban areas - where the most relevant geographical unit for effective management is not the river basin but the springshed, which do not follow the river valley contours. Springs draw upon mountain aquifers, which may be shared among multiple valleys; therefore, holistic water management must integrate mechanisms across river basins and springsheds in order to better coordinate surface and groundwater resource management.

In the HKH, a river-basin approach would harness the full potential of water resources while managing competing uses in the face of rising demand and increasing uncertainty (Shrestha et al. 2015b). Both infrastructure and institutional water-management approaches benefit from a river-basin perspective. Building institutional capacity at a river-basin scale can improve coordination between upstream and downstream areas. It can also improve cross-sectoral policies for water and energy. However, the river basins originating in the HKH often cross state or national borders, making coordinated basin-wide water management a question of riparian states' ability, institutional arrangements, and above all, political commitment to cooperate or at least creatively address conflicts.

Building transboundary institutional capacity is challenging due to the different needs and priorities of riparian states. River-basin management can even be difficult at the subnational level due to a lack of interstate institutional mechanisms, a predominance of local and community-based watermanagement schemes, and a lack of alignment among hydrologic boundaries and administrative management units.

At the local scale, much of the agricultural and domestic water supply is dependent upon mountain springs, whose 
aquifers do not necessarily follow the basin's surface boundaries. The basin approach may be useful at the meso and macro scales, but at the micro/local scale, formal institutions can prove useful by helping to link micro water-management institutions across valleys in order to address common issues of spring recharge, zone protection, and water quality. However, at the international transboundary level, the rivers originating within the HKH continue to be strongly contested, as outlined in Sect. 8.4.2.1.

\subsubsection{Transboundary Waters}

Transboundary resource sharing in South Asia has historically been fraught with contentious relationships, characterized by a focus on national interests, a lack of trust, and hegemonic power play. National interests and international power relations have played a significant role in hydro-politics in the region (Asthana and Shukla 2014). Despite being connected by hydrologic flows (Amu Darya, Indus, Ganges, Brahmaputra, Irrawaddy, Salween, and Mekong basins across national borders), states have often taken unilateral action on water-management decisions, leading to fragmented management of transboundary resources, narrow (albeit understandable) focus on national interests, and negative consequences for neighbouring riparian countries and communities (Asthana and Shukla 2014; Rasul 2014; Giordano et al. 2016).

Where international cooperation on water management exists, agreements are typically made between only two countries, and water disputes are often entangled with other political issues (Shah and Giordano 2013; Giordano et al. 2016). Several governments in the region have multiple challenges of achieving political consent for international water negotiations, whereas others are seen as regional hegemons. Bilateral water treaties often involve nation-states with disparate levels of political power. For example, in the Ganges-Brahmaputra-Meghna basins, India holds separate bilateral treaties with Nepal and Bangladesh, despite the fact that these three countries are all part of a larger shared basin. These water treaties are often inflexible and lack adequate mechanisms for negotiation of inter-party conflicts.

Bilateral water treaties in the region have resulted in varied outcomes for downstream states. Sometimes, transboundary water treaties have improved shared-resource management, but in other cases, the lack of an adequateor any-agreement has contributed to contentious state relations. The Indus Water Treaty, signed by India and Pakistan in 1960 and currently in effect, secured a significant apportionment of $80 \%$ of Indus River Basin flows for Pakistan, the lower riparian state (Shah and Giordano 2013).
India and Bhutan were able reach a mutually beneficial agreement on hydropower development in shared river basins; Bhutan earns over $60 \%$ of its national GDP from hydropower sales to India (Shah and Giordano 2013).

By contrast, treaties developed for joint hydropower projects on the Gandak, Koshi, and Mahakali Rivers (in 1952, 1954, and 1996, respectively) have tended to exacerbate tensions between India and Nepal. The Koshi agreement provided compensation to Nepal for land inundation, irrigation flows, and benefit sharing from a hydropower and flood-control project constructed by India within Nepalese territory. However, Nepal does not feel that the agreement has been upheld fairly (Shrestha et al. 2012; Giordano et al. 2016). Further, lack of bilateral agreement on required modifications of the Koshi project led to failure of the embankment of 2008, causing major flooding with severe damage and loss of life-and compounding the existing mistrust between these nations.

Water projects within the Brahmaputra and Ganges basins have also led to increased tensions between India and Bangladesh. India constructed the Farakka Barrage on the Ganges to divert dry-season flow for drinking-water and irrigation and to prevent sedimentation in Kolkata port. However, Bangladesh perceives the project as negatively impacting downstream water flows and delta productivity in Bangladesh.

Other projects have been developed unilaterally. India constructed a series of run-of-the-river hydropower projects and a diversion barrage on the Teesta River. Both projects negatively impact downstream Bangladesh. Although agreements on minimum flows and dispute resolution were reached between India and Bangladesh on these projects in 1996 and 1998, in both cases, Bangladesh remains dissatisfied with India's fulfillment of the terms of the agreements. To further complicate international agreement on water sharing, domestic protests within India have weakened the central government's ability to achieve an equitable arrangement with Bangladesh over the Farakka Barrage, an example of how international water cooperation is subverted by domestic political aims.

To redirect water management from conflict among international riparian states toward productive cooperation, joint water projects and research efforts are two ways to engage multiple players and build trust-while also serving to increase the knowledge base on resource issues, improve evidence-based decision making, identify mutually beneficial goals, and leverage cooperation within the scientific community to promote cooperation at other levels (Asthana and Shukla 2014). 
Cooperation will also lead to better planning of infrastructure projects, reducing impacts on resources, livelihoods, and ecosystems. Finally, regional information-sharing systems need to be established to facilitate open data exchange within river basins. Data sharing will help facilitate disaster management, increase capacity for information dissemination, improve regional resilience to climate change, and improve early-warning systems for floods-especially for glacial lake outbursts. However, questions about conflict and cooperation at multiple scales must also take into account interdependent resource systems, illustrated through the WEF security nexus and its unique manifestations within the HKH.

\subsubsection{The Water-Energy-Food Security Nexus}

There is a growing recognition of the important links between water, energy, and food. This triad is such that the security of one is impacted by or influences the others. This so-called WEF security nexus has emerged as an important conceptual paradigm for sustainable resource management. The nexus is considered to be a set of synergies and tradeoffs resulting from the inter-relations among resources, institutions, and security and the linkages between resource use and development, whereby interconnections can allow multiple needs to be addressed simultaneously. The tradeoffs and synergies are multi-dimensional, spanning physical and social spheres across multiple scales (Rasul 2014), both rural and urban (Scott et al. 2016).

The critical links among groundwater, energy, and irrigation have been highlighted in a number of studies. The proliferation of electric pumps for extracting groundwater in India (Mukherji 2007; Shah 2009; Bassi 2017) and of diesel pumps in Pakistan (Siddiqi and Wescoat 2013) has led to an extensive increase in energy consumption for agricultural production in the plains. Policy instruments, such as power tariff reforms, have been identified as interventions that can simultaneously reduce power demand (thereby improving energy supply for non-farm power needs), improve agricultural productivity, promote equity, and allow for more sustainable use of groundwater in agriculture (Kumar et al. 2013)

Within the mountainous regions of the HKH, the key WEF nexus linkages are principally through hydropower-electricity generation and irrigation, with important urban and rural implications that raise questions of political power and access (Allouche et al. 2015). In rural HKH regions especially, fuelwood for heating and cooking as well as rainfed agriculture for food production have WEF nexus implications. In the case of hydropower, off-grid, small-scale systems serving local communities have played an important development role in some areas (Pervaz and Rahman 2012). On the other hand, large, grid-connected hydropower systems serve regional energy demands with a distinct advantage for downstream agriculture and urban demands. In 2013, hydropower constituted a significant portion of total electricity production ( $\sim 77 \%$ in Nepal; $32 \%$ in Pakistan; and 12\% in India (IEA 2016)).

Overall, the WEF nexus at the micro/local scale in the $\mathrm{HKH}$ is not constituted by critical tradeoffs; rather it exists due to the essential need for water in both the energy and agricultural sectors. However, the prevailing system of access to and use of resources is vulnerable to disturbances in climate - and WEF security in rural areas will be significantly impacted (with the poor being exposed to higher risks). Small-scale hydropower systems will likely be the first affected by changes in streamflow due to climate change (as compared to large systems with significant storage capacity). Furthermore, landslides and floods that disrupt road connectivity in remote mountains will impact food imports and distribution to local markets.

The HKH has extensive hydropower-generation potential (estimated at $500 \mathrm{GW}$ ), and several large-scale systems are in operation or in stages of planning and development (Vaidya 2012). Power-generation revenue accrues at the provincial level (where power plants are situated); however, the electricity generated is largely used in the densely populated plains - as is stored water (for irrigated agriculture). For instance, Khyber Pakhtunkhwa (KPK) and Gilgit-Baltistan collectively host $76 \%(46 \mathrm{GW})$ of the 60 GW total estimated hydropower potential in Pakistan.

The irrigation benefits of the Indus waters are largely derived in the plains of Punjab and Sindh, whereas energy-generation revenues are accrued in KPK and Gilgit-Baltistan (Siddiqi and Wescoat 2013). An improved evaluation of the distribution of costs and benefits can allow for creating inclusive and equitable arrangements. For instance, a fraction of hydropower revenue could be provisioned for rural development of the province, and some of the new development projects could be directed toward adaptations for climate change impacts, such as deployment of photovoltaic (rather than micro-hydro) systems.

System-level modeling and analysis have largely focused on meso/basin- or macro/national-scale profits and benefits (Yang et al. 2014). As large projects are planned and funded by national agencies, the relevant scale of analysis has been at the provincial (meso) or national (macro) level. These approaches can be improved by incorporating methods and metrics that compute national-level net benefits in conjunction with local costs borne at smaller levels. 


\subsubsection{Decision-Making Improvements}

Water-related decision making across micro, meso, and macro scales is mediated by the relative social and political power of stakeholders and interest groups - and by complex and often involuted institutional histories and designs. At the micro level, the main conduits for decision making are predominantly informal local institutions. These institutions are embedded in the local-level geographies of power organized around class, ethnicity, and gender. To facilitate more inclusive decision-making structures, there is a need for greater synergy between the formal state and informal local institutions. The key political challenge is to make the informal local-level institutions accountable and equitable, without undermining their efficacy or legitimacy. Decision making by informal institutions at the local level is, indeed, based on local knowledge; therefore, there is a need for formal state institutions to learn from the local decision-making bodies.

At the meso/subnational scale, the balance of power is in favor of formal state institutions. Here, the key challenge is to steer what is generally politicized decision-making toward evidence-based decision-making, appropriately informed by science and local knowledge. At this scale, the importance of research and knowledge-generating actors cannot be overemphasized. Scientifically rigorous, socially informed, and locally relevant research could be made available to local level decision-makers, who, in turn, could also be made more accountable. As science points the way toward ecological and economic sustainability, accountability will ensure that attention is paid to social justice and sustainability.

At the macro/international scale, there is an obvious need for greater trust between the nation-states of the $\mathrm{HKH}$. Water conflicts rarely play out in isolation from the range of other issues between nation-states - but water can be a conduit for trust-building. Again, development that goes beyond design and construction could bring dimension to the largely engineering-focused perspective of the national water bureaucracies in the countries of the HKH.

Educating citizens and the press on water issues within the HKH could also provide a counterpoint to the focus on infrastructure and engineering that is currently predominant in addressing water problems in the region. Communicating to all stakeholders the importance of the socio-economic, cultural, spiritual, and ecological dimensions of water resources development is essential to maintain healthy and productive river basins. National water policies informed by multidisciplinary perspectives could help both national and regional initiatives find innovative solutions to seemingly intractable water conflicts, serving such programs as:
ICIMOD's Himalayan Adaptation, Water, and Resilience; Ganges Basin program of Water, Land, and Ecosystems under the Consultative Group for International Agricultural Research (CGIAR); and the South Asia Water Initiative. Finally, the link between subnational and national water politics cannot be overlooked. The aforementioned regional-level interventions could also serve to make national water policies more regionally and ecologically sensitive and less narrowly nationalistic.

\subsection{Challenges and Ways Forward}

Water availability, use, and governance in the HKH are in a constant state of flux. In terms of availability, annual river flows across the HKH during this century in general will not undergo great change because increased precipitation and runoff will tend to counteract reduced flow from glacial melt, except in the Indus and other western basins where contributions from monsoon precipitation are low. However, pre-monsoon flows are expected to decline, impacting irrigation, hydropower, and ecosystem services. Data uncertainties are high, and they cannot easily account for spatial and temporal heterogeneity. Projections indicate that intra-annual variability in surface water will increase. There is anecdotal evidence that springs in the mid-hills of the Himalaya are drying up. These contribute to lean season baseflow in local streams, which are the primary source of drinking water in the $\mathrm{HKH}$ mid-hills before joining the rivers fed by glacial melt. Despite high proportions of water use in agriculture throughout the region, increased urban demand for water will continue, based on population growth and the concentration of economic and political power in cities and towns. Meeting SDG targets focused on urban water supply, wastewater, and sanitation will place unprecedented pressure on water resources in HKH cities. In the future, it is likely that larger cities in and around the $\mathrm{HKH}$ will resort to long-distance water transfers from HKH highlands to satisfy increasing demand, possibly designing suitable institutions for payment to upstream communities for ecosystem services. It is also likely that some of the bigger cities will invest in workable wastewater-treatment infrastructure. However, the real crisis will occur in smaller emerging towns, which have inadequate funds for infrastructure upgrades, particularly for water supply and wastewater treatment, and lack suitable governance institutions.

Reduced lean-season river flow coupled with increasing urban and upstream demand will result in reduced availability of surface water to downstream farmers for irrigation. Agriculture and irrigation will become increasingly 
feminized, and formal and informal institutions must respond to this reality, or mountain agriculture and irrigation systems will stagnate or shrink. For example, most FMIS still consider members to be landowners, who are men, many of whom have migrated. If institutions become inclusive, and if remittance money is invested in agriculture, then it is possible that the shift to remunerative crops like coffee, orchards, and mountain niche crops (instead of rainfed cereals) will become even more pronounced.

Hydropower is rapidly emerging as the main source of energy and revenue for Himalayan states, but changing river flow regimes will require hydropower projects to be constructed and managed in order to account for pre-existing water use for irrigation. Without mechanisms to negotiate water sharing between existing agricultural and emerging hydropower uses, the water available for agriculture will decline in localized areas. There is a need for improved benefit-sharing norms that enable the preservation of water flows for agricultural use while allowing substantial, but mediated, hydropower development.

Ecosystem flows in Himalayan rivers and streams are subject to flow regimes that are heavily impacted by human water uses. The greatest impacts on fish, macroinvertebrates, and other riverine flora and fauna result from increasing intra-annual variability of river flows, even though inter-annual variability in flood and drought cycles certainly affects riparian ecosystems. Increasing intra-annual variability will reduce lean-season flows and diminish the high-monsoon flows characteristic of HKH regimes.

Acknowledgements The participation of Christopher Scott and Tamee Albrecht was made possible through the support of the International Water Security Network, a project funded by Lloyd's Register Foundation, a charitable foundation helping protect life and property by supporting engineering-related education, public engagement and the application of research.

\section{References}

Abbas, N., \& Subramanian, V. (1984). Erosion and sediment transport in the Ganges river basin (India). Journal of Hydrology, 69(1-4), $173-182$.

ADB. (2014). Sector Assessment (summary): Agriculture, natural resources, and rural development. Country partnership strategy: Bhutan, 2014-2018. Manila: The Asian Development Bank.

Agarwal, A., Bhatnagar, N., Nema, R., \& Agrawal, N. K. (2012). Rainfall dependence of springs in the Midwestern Himalayan hills of Uttarakhand. Mountain Research and Development, 32(4), 446-455.

Al-Faraj, F. A. M., \& Scholz, M. (2014). Impact of upstream anthropogenic river regulation on downstream water availability in transboundary river watersheds. International Journal of Water Resources Development, 31, 28-49.

Ali, K. F., \& De Boer, D. H. (2007). Spatial patterns and variation of suspended sediment yield in the upper Indus River basin, northern Pakistan. Journal of Hydrology, 334(3), 368-387.

Allouche, J., Middleton, C., \& Gyawali, D. (2015). Technical veil, hidden politics: Interrogating the power linkages behind the nexus. Water Alternatives, 8, 610-626.

Amin, A., Fazal, S., Mujtaba, A., \& Singh, S. K. (2014). Effects of land transformation on water quality of Dal Lake, Srinagar, India. Journal of the Indian Society of Remote Sensing, 42, 119-128.

Andermann, C., Longuevergne, L., Bonnet, S., Crave, A., Davy, P., \& Gloaguen, R. (2012). Impact of transient groundwater storage on the discharge of Himalayan rivers. Nature Geoscience, 5(2), $127-132$.

Archer, D. (2003). Contrasting hydrological regimes in the upper Indus Basin. Journal of Hydrology, 274(1-4), 198-210. http://linkinghub. elsevier.com/retrieve/pii/S0022169402004146. Accessed 11 Oct. 2013.

Arthington, A. H., Bunn, S. E., Poff, N. L., \& Naiman, R. J. (2006). The challenge of providing environmental flow rules to sustain river ecosystems. Ecological Applications, 16, 1311-1318.

Aryal, K., \& Choudhury, D. (2015). Climate change: Adaptation, mitigation and transformations of swidden landscapes: Are we throwing the baby out with the bathwater? In M. F. Cairns (Ed.), Shifting Cultivation and environmental change: Indigenous people, agriculture and forest conservation (pp. 281-288). New York: Routledge.

Ashraf, A., \& Ahmad, Z. (2008). Regional groundwater flow modeling of Upper Chaj Doab of Indus Basin, Pakistan using finite element model (Feflow) and geoinformatics. Geophysical Journal International, 173, 17-24.

Ashraf, A. (2013). Changing hydrology of the Himalayan watershed, current perspectives, in contaminant hydrology and water resources sustainability, Dr. P. Bradley (Ed.). ISBN: 978-953-51-1046-0, InTech, https://doi.org/10.5772/54492.

Ashraf, A., Abuzar, M. K., Ahmad, B., Ahmad, M. M., \& Hussain, Q. (2017). Modeling risk of soil erosion in high and medium rainfall zones of Pothwar region, Pakistan. Proceedings of the Pakistan Academy of Sciences: Pakistan Academy of Sciences: B. Life and Environmental Sciences, 54(2), 67-77.

Asthana, V., \& Shukla, A. C. (2014). Water security in India: hope, despair, and the challenges of human development. Bloomsbury Publishing USA.

Babel, M. S., \& Wahid, S. M. (2009). Freshwater under threat South East Asia: Vulnerability assessment of freshwater resources to environmental change: Ganges-Brahmaputra-Meghna River Basin, Helmand River Basin, and Indus River Basin. United Nations Environment Programme.

Baghel, R., \& Nüsser, M. (2010). Discussing large dams in Asia after the World Commission on Dams: Is a political ecology approach the way forward? Water Alternatives, 3(2), 231-248.

Bajracharya, S. R., Maharjan, S. B., Shrestha, F., Bajracharya, O. R., \& Baidya, S. (2014). Glacier status in Nepal and decadal change from 1980 to 2010 based on landsat data. Kathmandu: ICIMOD.

Baker, J. M. (2005). The Kuhls of Kangra: Community managed irrigation in the Western Himalaya. New Delhi: Permanent Black.

Bandyopadhyay, J. (2017). Restoration of ecological status of Himalayan rivers in China and India: The case of the two mother rivers-The Yellow and the Ganges. In S. Dong, J. Bandyopadhyay, \& S. Chaturvedi (Eds.), Environmental Sustainability from the 
Himalayas and the oceans: Struggles and innovations in China and India (pp. 69-98), Chap. 4. Switzerland: Springer.

Bandyopadhyay, J. (2002). A critical look at the report of the World Commission on Dams in the context of the debate on the large dams on the Himalayan rivers. Water Resource Development, 18(1), 127-145.

Bandyopadhyay, J. (2009). Climate change and Hindu Kush-Himalayan waters-knowledge gaps and priorities in adaptation. Sustainable Mountain Development, 56(56), 17-20.

Bangladesh Bureau of Statistics. (2015). Yearbook of agricultural statistics-2013, 25th Series, Bangladesh Bureau of Statistics (BBS), Statistics and Informatics Division (SID), Ministry of Planning, Government of the People's Republic of Bangladesh.

Bangladesh Power Development Board. (2014). Annual Report, downloaded from http://www.bpdb.gov.bd/download/annual_ report/Annual\%20Report\%202014-15.pdf 12th June 2016.

Barlow, M., et al. (2005). Modulation of daily precipitation over East Africa by the Madden-Julian oscillation. Monthly Weather Review, 133, 3579-3594.

Bashir, F., Zeng, X., Gupta, H., \& Hazenberg, P. (2017). A hydrometeorological perspective on the Karakoram Anomaly using unique valley-based synoptic weather observations. Geophysical Research Letters, 44, 10470-10478.

Bassi, N. (2017). Solarizing groundwater irrigation in India: A growing debate. International Journal of Water Resources Development. https://doi.org/10.1080/07900627.2017.1329137.

Bastakoti, R. C., Ale, M., \& Shivakoti, G. (2015). Robustness-vulnerability characteristics of irrigation systems in Nepal. In P. Pradhan, U. Gautam, \& N. M. Joshi (Eds.), Small scale irrigation systems: Challenges to sustainable livelihood (p. 374). Kathmandu: Farmer Managed Irrigation Systems Promotion Trust.

Bastakoti, R. C., Maskey, N., Drechsel, P., \& Prasad, S. (2014). Wastewater irrigation in urban agriculture.

Bharati, L., Gurung, P., Jayakody, P., Smakhtin, V., \& Bhattarai, U. (2014). The projected impact of climate change on water availability and development in the Koshi Basin, Nepal. Mountain Research and Development, 34(2), 118-130.

Biggs, E. M., Duncan, J. M., Atkinson, P. M., \& Dash, J. (2013a). Plenty of water, not enough strategy: How inadequate accessibility, poor governance and a volatile government can tip the balance against ensuring water security: The case of Nepal. Environmental Science \& Policy, 33, 388-394.

Biggs, E. M., Tompkins, E. L., Allen, J., Moon, C., \& Allen, R. (2013b). Agricultural adaptation to climate change: Observations from the Mid-Hills of Nepal. Climate and Development, 5(2), 165173. https://doi.org/10.1080/17565529.2013.789791.

Blöthe, J. H., \& Korup, O. (2013). Millennial lag times in the Himalayan sediment routing system. Earth and Planetary Science Letters, 382, 38-46.

Bolch, T., Pieczonka, T., Mukherjee, K., \& Shea, J. (2017). Brief communication: Glaciers in the Hunza catchment (Karakoram) have been nearly in balance since the 1970s. The Cryosphere, 11, 531539. https://doi.org/10.5194/tc-11-531-2017, 2017.

Bookhagen, B., \& Burbank, D. W. (2010). Toward a complete Himalayan hydrological budget: Spatiotemporal distribution of snowmelt and rainfall and their impact on river discharge. Journal of Geophysical Research: Earth Surface, 115(F3).

Butz, D. (1989). The agricultural use of melt water in Hopar settlement, Pakistan. Annals of Glaciology, 13, 35-39.

Central Electricity Authority. (2016). http://www.cea.nic.in/index.html data downloaded on 12th June, 2016. Government of India.
Central Water Comission. (2014). National register of large dams. Dams of national importance (completed and under construction). Central Water Commission. Ministry of Water Resource. Government of India, $207 \mathrm{pp}$.

Chakraborty, T., Kar, R., Ghosh, P., \& Basu, S. (2010). Kosimegafan: Historical records, geomorphology and the recent avulsion of the Kosi River. Quaternary International, 227, 143-160.

Chandra Regmi, S., \& Fawcett, B. (1999). Integrating gender needs into drinking water projects in Nepal. Gender and Development (Vol 7.3, pp. 62-72). Oxfam, Oxford.

Chen, Z., Li, J., Shen, H., et al. (2001). Yangtze river of China: Historical analysis of discharge variability and sediment flux. Geomorphology, 41(2), 77-91.

China Statistical Year Book. (2015). http://www.stats.gov.cn/tjsj/ndsj/ 2015/indexeh.htm on 15th June 2016, published by China Statistical Press, Government of People's Republic of China, Beijing.

Coffey, D., Gupta, A., Hathi, P., Spears, D., Srivastav, N., \& Vyas, S. (2015). Culture and the health transition: Understanding sanitation behaviour in rural north India. IGC Working Paper, April 2015. https://pdfs.semanticscholar.org/f63e/ c230b37b7275185c8a35b8bc551af0808754.pdf.

Colopy, C. (2012). Dirty, sacred rivers: Confronting South Asia's water crisis. New York, NY: Oxford University Press.

CPCB. (2013). Pollution assessment: River Ganga. Delhi: Central Pollution Control Board.

Dahri, Z. H., et al. (2016). An appraisal of precipitation distribution in the high-altitude catchments of the Indus basin. Science of the Total Environment, 548-549, pp. 289-306. http://www.sciencedirect. com/science/article/pii/S0048969716300018.

De Spoelberch, G. (1987). A model: The Aga Khan rural support program. Challenge, 29(6), 26-31.

Diduck, A. P., Pratap, D., Sinclair, A. J., \& Deane, S. (2013). Perceptions of impacts, public participation, and learning in the planning, assessment and mitigation of two hydroelectric projects in Uttarakhand, India. Land Use Policy, 33, pp.170-182.

Dixit, A. (2009). Kosi embankment breach in Nepal: Need for a paradigm shift in responding to floods. Economic and Political Weekly, 44(6), 70-78.

Dixit, A., \& Upadhya, M. (2005). Augmenting groundwater in Kathmandu Valley: Challenges and possibilities. Nepal water conservation foundation, Kathmandu, Nepal.

Ehsan-ul-Haq. (2007). Community response to climatic hazards in Northern Pakistan. Mountain Research and Development, 27(4), 308-312.

Erlewein, A. (2013). Disappearing rivers-The limits of environmental assessment for hydropower in India. Environmental Impact Assessment Review, 43, 135-143.

Erlewein, A., \& Nüsser, M. (2011). Offsetting greenhouse gas emissions in the Himalaya? Clean development dams in Himachal Pradesh, India. Mountain Research and Development, 31(4), 293-302.

FAO. (2016a). AQUASTAT. http://www.fao.org/nr/water/aquastat/ water_res/index.stm downloaded on 11th June, 2016, Food and Agricultural Organization, Rome.

FAO. (2016b). AQUASTAT, FAO. (http://www.fao.org/nr/water/ aquastat/water_use/index.stm) downloaded on 12th of June 2016. Food and Agricultural Organization, Rome.

FAO. (2016c). AQUASTAT. http://www.fao.org/nr/water/aquastat/ irrigationmap/chn/index.stm downloaded on 15th of June, 2016. Global Map of Irrigated Area Statistics for China. Food and Agricultural Organization, Rome. 
FAO. (2016d). AQUASTAT.http://www.fao.org/nr/water/aquastat/ irrigationmap/MMR/index.stm downloaded on 15th of June, 2016. Global Map of Irrigated Area Statistics for China. Food and Agricultural Organization, Rome.

Fort, M. (2015). Natural hazards versus climate change and their potential impacts in the dry, northern Himalayas: Focus on the upper Kali Gandaki (Mustang District, Nepal). Environmental Earth Sciences, 73(2), 801-814.

Galewsky, J. (2009). Orographic precipitation isotopic ratios in stratified atmospheric flows: Implications for paleoelevation studies. Geology, 37(9), 791-794.

Ghosh, A., \& Cairncross, S. (2014). The uneven progress of sanitation in India. Journal of Water, Sanitation and Hygiene Development, 4 (1), 15-22.

Giordano, M., Gyawali, D., Nishat, A., \& Sinha, U. (2016). Can there be progress on trans-boundary water cooperation in the Ganga? In L. Bharati, B. R. Sharma, \& V. Smakhtin (Eds.), The Ganges river Basin: Status and challenges in water, environment and livelihoods. London: Routledge.

Giosan, L., Syvitski, J., Constantinescu, S., et al. (2014). Climate change: Protect the world's deltas. Nature, 516(7529), 31-33.

Gole, C. V., \& Chitale, S. V. (1966). Inland delta building activity of Kosi river. Journal of the Hydraulics Division ASCE, 91, 111-126.

Gosh (ND) Pollution from non-point sources in Ganga Basin: A Community-based potential for managing the unmarked crisis.

Government of Afghanistan, Ministry of Energy and Water, 2006.

Government of India, GOI. (2011). Report of the 4th Minor Irrigation Census. Ministry of Water Resources Development, New Delhi, Government of India.

Government of Nepal. (2016). Groundwater resources development board, Ministry of Irrigation, Government of Nepal, data downloaded on 12th June, 2016. http://www.gwrdb.gov.np/ hydrogeological_studies.php.

Government of Pakistan. (2010). Agricultural census 2010-Pakistan Report. http://www.pbs.gov.pk/content/agricultural-census-2010pakistan-report. 12 June 2016.

Grumbine, R. E., \& Pandit, M. K. (2013). Threats from India's Himalaya Dams. Science, 339, 36-37.

Hewitt, K. (2011). Glacier change, concentration, and elevation effects in the Karakoram Himalaya, Upper Indus Basin. Mountain Research and Development, 31(3), 188-200.

ICIMOD. (2014). International conference on mountain people adapting to change: Solutions beyond boundaries bridging science, policy, and practice. Kathmandu, Nepal, 9-12 November 2014.

ICIMOD. (2011a). Glacial lakes and glacial lake outburst floods in Nepal. Kathmandu: ICIMOD.

ICIMOD. (2011b). Mountain, green economy for sustainable development: A concept paper for Rio +20 and beyond. In International Conference on Green Economy and Sustainable Mountain Development Opportunities and Challenges in View of Rio +20 (p. 31).

IEA. (2016). https://www.iea.org/statistics/. International Energy Association.

IITC. (2010). River Ganga at a glance: Identification of issues and priority actions for restoration; 001_GBP_IIT_GEN_DAT_01_Ver 1_Dec 2010.

Immerzeel, W. W., Van Beek, L. P. H., \& Bierkens, M. F. P. (2010). Climate change will affect the Asian water towers. Science, 328 (5984), 1382-1385. https://doi.org/10.1126/science.1183188.

Immerzeel, W. W., et al. (2011). Hydrological response to climate change in a glacierized catchment in the Himalayas. Climatic
Change, 110, 721-736. http://www.springerlink.com/index/10. 1007/s10584-011-0143-4. Accessed 2 Aug. 2011.

Immerzeel, W. W., et al. (2015). Reconciling high altitude precipitation with glacier mass balances and runoff. Hydrology and Earth System Sciences, 12, 4755-4784.

Immerzeel, W. W., Pellicciotti, F., \& Bierkens, M. F. P. (2013). Rising river flows throughout the twenty-first century in two Himalayan glacierized watersheds. Nature Geoscience, 6, 742-745. http:// www.nature.com/doifinder/10.1038/ngeo1896. Accessed 5 Aug. 2013.

International Hydropower Association. (2016). https://www. hydropower.org/country-profiles downloaded on 12th June, 2016.

Ishaq, M., \& Farooq, A. (2016). Farming in the northern mountains of Pakistan: Role of women. Retrieved from http://lib.icimod.org/ record/12328/files/1006.pdf on 12 June 2016.

Islam, M. R., Begum, S. F., Yamaguchi, Y., \& Ogawa, K. (1999). The Ganges and Brahmaputra rivers in Bangladesh: Basin denudation and sedimentation. Hydrological Processes, 13(17), 2907-2923.

Janakarajan, S., \& Moench, M. (2006). Are wells a potential threat to farmers' well-being? Case of deteriorating groundwater irrigation in Tamil Nadu. Economic and Political Weekly, 41(37), 3977-3987.

Janssen, M. A., \& Anderies, J. M. (2013). A multi-method approach to study robustness of social-ecological systems: The case of small-scale irrigation systems. Journal of Institutional Economics, 9(04), 427-447. http://dx.doi.org/10.1017/S1744137413000180.

Jeelani, G. (2008). Aquifer response to regional climate variability in a part of Kashmir Himalaya in India. Hydrogeology Journal, 16(8), $1625-1633$.

Karn, S. K., \& Harada, H. (2001). Surface water pollution in three urban territories of Nepal, India, and Bangladesh. Environmental Management, 28(4), 483-496.

Kaser, G., Großhauser, M., \& Marzeion, B. (2010). Contribution potential of glaciers to water availability in different climate regimes. Proceedings of the National Academy of Sciences, 107 (47), 20223-20227.

Kc, K. (2003). Optimizing water use in Kathmandu valley (ADB TA-3700), Final Draft Report on Groundwater/Hydrogeology in Kathmandu Valley.

Khan, A. N. (1987). Spate irrigation in Pakistan. In FAO/UNDP, Spate irrigation: Proceedings of the Subregional Expert Consultation on Wadi Development for Agriculture in Natural Yemen, 6-10 December 1987 (pp. 167-170). Rome: FAO.

Khan, K., Lu, Y., Khan, H., Zakir, S., Khan, S., Khan, A. A., et al. (2013). Health risks associated with heavy metals in the drinking water of Swat, northern Pakistan. Journal of Environmental Sciences, 25(10), 2003-2013.

Khattak, M. S., Babel, M. S., \& Sharif, M. (2011). Hydro-meteorological trends in the upper Indus River basin in Pakistan. Climate Research, 46(2), 103-119. http://www.int-res. com/abstracts/cr/v46/n2/p103-119/. Accessed 29 Nov. 2012.

Kresic, N., \& Stevanovic, Z. (2009). Groundwater hydrology of springs. Butterworth-Heinemann.

Kreutzmann, H. (2011). Scarcity within Opulence: Water management in the Karakoram mountains revisited. Journal of Mountain Science, 8, 525-534.

Kumar, D., Scott, C. A., \& Singh, O. P. (2013). Can India raise agricultural productivity while reducing groundwater and energy use? International Journal of Water Resources Development, 29(4), 557-573. 
Kumar, K., Satyal, G. S., \& Kandpal, K. D. (2006). Farmer and state managed hill irrigation systems in Kumaun Himalayas. Indian Journal of Traditional Knowledge, 5(1), 132-138.

Kumar, V., Sen, S. (2017a). Assessment of spring potential for sustainable agriculture: A case study in lesser Himalayas. Agricultural Water Management. (under review).

Kumar, V., Sen, S. (2017b). Evaluation of spring discharge dynamics using recession curve analysis: a case study in data-scarce region, Lesser Himalayas, India. Sustainable Water Resources Management, 1-19. (in press).

Laghari, A. N., Abbasi, H. U., Aziz, A., \& Kanasaro, N. A. (2015). Impact analyses of upstream water infrastructure development schemes on downstream flow and sediment discharge and subsequent effect on Deltaic region. Sindh University Research Journal, 47, 805-808.

Lapworth, D., MacDonald, A., Krishan, G., Rao, M., Gooddy, D., \& Darling, W. (2015). Groundwater recharge and age-depth profiles of intensively exploited groundwater resources in northwest India. Geophysical Reseach Letters, 42(18), 7554-7562.

Livingston, M. (2009). Deep wells and prudence: Towards pragmatic action for addressing groundwater overexploitation in India, Report. World Bank.

Lutz, A. F., et al. (2014). Consistent increase in High Asia's runoff due to increasing glacier melt and precipitation. Nature Climate Change, 4, 587-592.

Mahamuni, K., \& Kulkarni, H. (2012). Groundwater resources and spring hydrogeology in South Sikkim, with special reference to climate change, climate change in Sikkim patterns, impacts and initiatives. Information and Public Relations Department, Government of Sikkim, Gangtok.

Maleta, H., \& Favre, R. (2003). Agriculture and food production in post-war Afghanistan: A report on the winter agricultural survey, 2002-03, p. 29; Joint report of Ministry of Agriculture and Animal Husbandry, FAAHM, Government of Afghanistan and Food, Agriculture and Animal Husbandry Information Management and Policy Unit of the Food and Agriculture Organization of the United Nations.

Mateo-Sagasta, J., Tare, V. (2016). Ganga water quality: Dirty past, promising future? In L. Bharati, B. R. Sharma, V. Smakhtin (Eds.) The Ganges River Basin: Status and challenges in water, environment and livelihoods (pp. 222-237). Oxon, UK: RoutledgeEarthscan. (Earthscan Series on Major River Basins of the World).

Mazumder, S. K. (2011). Protection of flood embankments by spurs with reference to Kosi River. In Proceedings of HYDRO-2011, SVNIT. Surat.

Mehari, A., van Steenbergen, F., \& Schultz, B. (2007). Water rights and rules, and management in spate irrigation systems in Eritrea, Yemen and Pakistan. In B. van Koppen, M. Giordano, \& J. Butterworth (Eds.), Community-based Water Law and Water Resource Management Reform in Developing Countries (Comprehensive assessment of water management in agriculture; 5) (pp. 114-129). Oxfordshire: CABI Publishers.

McCarthy, J., \& Mustafa, D. (2014). Despite the best intentions? Experiences with water resource management in northern Afghanistan. In E. Weinthal, J. Troell, \& M. Nakayama (Eds.), Water and post-conflict peacebuilding. London: Earthscan.

Merz, J., Nakarmi, G., Shrestha, S. K., Dahal, B. M., Dangol, P. M., Dhakal, M. P., et al. (2003). Water: A scarce resource in rural watersheds of Nepal's Middle Mountains. Mountain Research and Development, 23(1), 41-49.
Meybeck, M. (1976). Total annual dissolved transport by world major rivers. Bulletin Hydrological Sciences, 21, 265-289.

Michael, H. A., \& Voss, C. I. (2009). Controls on groundwater flow in the Bengal Basin of India and Bangladesh: Regional modeling analysis. Hydrogeology Journal, 17(7), 1561-1577.

Milliman, J. D., \& Meade, R. H. (1983). World-wide delivery of river sediment to the oceans. The Journal of Geology, 91(1), 1-21.

Molden, O., Griffin, N., \& Meehan, K. (2016). The cultural dimensions of household water security: The case of Kathmandu's stone spout systems. Water International. https://doi.org/10.1080/02508060. 2016.1251677.

Ministry of Water Resources (MoWR). (2010). The report of the Krishna Water Disputes Tribunal. MoWR, Government of India. http://wrmin.nic.in/writereaddata/Inter-StateWaterDisputes/ KWDTReport9718468760.pdf. 1 Sept. 2017.

Mishra, K., Sinha, R., Manohar, K. V. S., \& Jain, V. (2016). Sediment dynamics and sediment connectivity in the Koshi basin: implications for river hazards. Kathmandu: Unpublished Report, ICIMOD.

Moench, M. (2007). When the wells run dry but livelihood continues: Adaptive responses to groundwater depletion and strategies for mitigating the associated impacts. In M. Giordano \& K. G. Villholth (Eds.), The agricultural groundwater revolution: Opportunities and threats to development. CABI Publishers, UK (pp. 173-192) (Comprehensive Assessment of Water Management in Agriculture Series No. 3).

Molden, D. J., Vaidya, R. A., Shrestha, A. B., \& Shrestha, M. S. (2014). Water infrastructure for the Hindu Kush Himalayas. International Journal of Water Resources Development, 30(1), 60-77.

Mollinga, P. P. (2009). Water rights in Farmer Managed Irrigation Systems in India: Equity, rule making, hydraulic property and the ecology. SAWAS South Asia Water Studies, 1(1), 1-18.

Mukherji, A. (2007). The energy-irrigation nexus and its impact on groundwater markets in eastern Indo-Gangetic basin: Evidence from West Bengal, India. Energy Policy, 35, 6413-6430.

Mukherji, A., Pradhan, N., Shrestha, R., Bhuchar, S., Dhakal, M., Gurung, K. et al. (2016). Springs and springsheds: ICIMOD position paper. Unpublished internal document available on request.

Mukherji, A., Molden, D., Nepal, S., Rasul, G., \& Wagnon, P. (2015). Himalayan waters at the crossroads: Issues and challenges: Editorial. International Journal of Water Resources Development, 31(2), 151-160.

Mukhopadhyay, B., \& Khan, A. (2014a). A quantitative assessment of the genetic sources of the hydrologic flow regimes in Upper Indus Basin and its significance in a changing climate. Journal of Hydrology, 509, 549-572. http://linkinghub.elsevier.com/retrieve/ pii/S0022169413008834. Accessed 6 Feb. 2014.

Mukhopadhyay, B., \& Khan, A. (2014b). Rising river flows and glacial mass balance in central Karakoram. Journal of Hydrology, 513, 192-203. http://linkinghub.elsevier.com/retrieve/pii/ S0022169414002273. Accessed 17 July 2014.

Mukhopadhyay, B., \& Khan, A. (2015). A reevaluation of the snowmelt and glacial melt in river flows within Upper Indus Basin and its significance in a changing climate. Journal of Hydrology, 527, 119-132. http://dx.doi.org/10.1016/j.jhydrol.2015.04.045.

Nag, D., \& Phartiyal, B. (2015). Climatic variations and geomorphology of the Indus River valley, between Nimo and Batalik, Ladakh (NW Trans Himalayas) during Late Quaternary. Quaternary International, 371, 87-101. 
Narula, K. K., \& Gosain, A. (2013). Modeling hydrology, groundwater recharge and non-point nitrate loadings in the Himalayan Upper Yamuna basin. Science of the Total Environment, 468, S102-S116.

Negi, G. C., \& Joshi, V. (2004). Rainfall and spring discharge patterns in two small drainage catchments in the Western Himalayan Mountains. India, Environmentalist, 24(1), 19-28.

Negi, G., Samal, P., Kuniyal, J., Kothyari, B., Sharma, R., \& Dhyani, P. (2012). Impact of climate change on the western Himalayan mountain ecosystems: An overview. Tropical Ecology, 53(3), 345356.

Nepal, S., Flügel, W.-A., \& Shrestha, A. B. (2014a). Upstream-downstream linkages of hydrological processes in the Himalayan region Ecol. Process, 3, 1-16.

Nepal, S., Krause, P., Flügel, W.-A., Fink, M., \& Fischer, C. (2014b). Understanding the hydrological system dynamics of a glaciated alpine catchment in the using the J2000 hydrological model. Hydrological Processes, 28, 1329-1344.

Nepal, S., Shrestha, A. B. (2015). Impact of climate change on the hydrological regime of the Indus, Ganges and Brahmaputra river basins: A review of the literature. International Journal of Water Resources Development, 1-18.

Nüsser, M., Schmidt, S., \& Dame, J. (2012). Irrigation and development in the Upper Indus Basin: Characteristics and recent changes of a socio-hydrological system in Central Ladakh, India. Mountain Research and Development, 32(1), 51-61.

Nüsser, M. (2001). Understanding cultural landscape transformation: A re-photographic survey in Chitral, Eastern Hindukush, Pakistan. Landscape and Urban Planning, 57(241-255).

Nüsser, M., \& Baghel, R. (2016). Local knowledge and global concerns: Artificial glaciers as a focus of environmental knowledge and development interventions. In Meusburger et al. (Eds.), Ethnic and cultural dimensions of knowledge (pp. 191-209). Dordrecht: Springer.

Nüsser, M., \& Schmidt, S. (2017). Nanga Parbat revisited: Evolution and dynamics of sociohydrological interactions in the Northwestern Himalaya. Annals of the American Association of Geographers, 107 (2), 403-415.

Ostrom, E., \& Benjamin, P. (1993). Design principles and the performance of farmer managed irrigation systems in Nepal. In S. Manor \& J. Chambouleyron (Eds.). Performance measurement in farmer managed irrigation systems, (IIMI, 1993) (pp. 53-62).

Ostrom, E., \& Gardner, R. Coping with asymmetries in the commons: Self-Governing Irrigation Systems Can Work. Journal of Economic Perspectives, 7, 93-112. Number 4-Fall 1993.

Pandey, V. P., \& Kazama, F. (2011). Hydrogeologic characteristics of groundwater aquifers in Kathmandu Valley, Nepal. Environmental Earth Sciences, 62(8), 1723-1732.

Pandey, V. P., Chapagain, S. K., \& Kazama, F. (2010). Evaluation of groundwater environment of Kathmandu Valley. Environmental Earth Sciences, 60(6), 1329-1342.

Pandey, V., Shrestha, S., \& Kazama, F. (2012). Groundwater in the Kathmandu Valley: Development dynamics, consequences and prospects for sustainable management. European Water, 37, 3-14.

Pant, B. R. (2011). Ground water quality in the Kathmandu valley of Nepal. Environmental Monitoring and Assessment, 178(1-4), 477485.

Paramanik, S. K. (2017). Analysis of discharge variation and estimation of recession coefficients for different spring systems in Himalayan terrain. Indian Institute of Technology Roorkee: Master Degree.
Parveen, S., Winiger, M., Schmidt, S., \& Nüsser, M. (2015). Irrigation in Upper Hunza: Evolution of socio-hydrological interactions in the Karakoram, Northern Pakistan, Erdkunde, Bd. 69, H. 1 (JanuaryMarch 2015, pp. 69-85).

Pervaz, M., \& Rahman, M. L. (2012). Review and evaluation of successful and unsuccessful renewable energy projects in South Asia. In International Conference on Life Science and Engineering, Singapore. https://doi.org/10.7763/ipcbee. V45. 2.

Poff, N. L., Allan, J. D., Bain, M. B., Karr, J. R., Prestegaard, K. L. et al. (1997). The natural flow regime: a paradigm for river conservation and restoration. BioScience, 47, 769-784.

Pokhrel, A. (2014). A theory of sustained cooperation with evidence from irrigation institutions in Nepal. Ph.D. dissertation, Massachusetts Institute of Technology (MIT)_Urban Studies and Planning, International Development, Political Economy. USA.

Poudel, D. D., \& Duex, T. W. (2017). Vanishing springs in Nepalese mountains: Assessment of water sources, farmers's perceptions, and climate change adaptation. Mountain Research and Development, $37(1), 35-46$.

Pradhan, P. (2000). Farmer managed irrigation system in Nepal at the Crossroads. In Paper presented at the 8th Biennial Conference of the International Association for the Study of Common Property (IASCP), Bloomington, Indiana, May 30 to 4 July, 2000. http://dlc. dlib.indiana.edu/dlc/bitstream/handle/10535/331/pradhanp041500. pdf?sequence $=$. Accessed 13 August 2016.

Prasch, M., Mauser, W., \& Weber, M. (2013). Quantifying present and future glacier melt-water contribution to runoff in a central Himalayan river basin. The Cryosphere, 7(3), 889-904. http:// www.the-cryosphere.net/7/889/2013/. Accessed 24 Sept. 2013.

Raina, A. (2016). Equity in urban water service delivery and the role of informal water vendors: The case of Kathmandu valley, Nepal (Unpublished Doctoral Dissertation). Singapore: National University of Singapore.

Racoviteanu, A. E., Armstrong, R., \& Williams, M. W. (2013). Evaluation of an ice ablation model to estimate the contribution of melting glacier ice to annual discharge in the Nepal Himalaya. Water Resources Research, 49(9), 5117-5133. http://doi.wiley.com/ 10.1002/wrcr.20370. Accessed 23 Dec. 2013.

Ragettli, S., et al. (2013). Sources of uncertainty in modeling the glacio-hydrological response of a Karakoram watershed to climate change. Water Resources Research, 49, 1-19. http://doi.wiley.com/ 10.1002/wrcr.20450. Accessed 24 Sept. 2013.

Ragettli, S., et al. (2015). Unraveling the hydrology of a Himalayan watershed through integration of high resolution in-situ data and remote sensing with an advanced simulation model. Advances in Water Resources, 78, 94-111. http://dx.doi.org/10.1016/j. advwatres.2015.01.013.

Rana, S., \& Gupta, V. (2009). Watershed management in the Indian Himalayan region: Issues and challenges. In Paper presented at World Environmental and Water Resources Congress 2009@ sGreat Rivers, ASCE.

Rasul, G. (2009). Ecosystem services and agricultural land-use practices: A case study of the Chittagong Hill Tracts of Bangladesh. Sustainability: Science, Practice and Policy, 5(2).

Rasul, G. (2014). Food, water, and energy security in South Asia: A nexus perspective from the Hindu Kush Himalayan region. Environmental Science \& Policy, 39, 35-48.

Rodell, M., Velicogna, I., \& Famiglietti, J. S. (2009). Satellite-based estimates of groundwater depletion in India. Nature, 460(7258), 999-1002. 
Safi, Z., \& Buerkert, A. (2011). Heavy metal and microbial loads in sewage irrigated vegetables of Kabul, Afghanistan. Journal of Agriculture and Rural Development in the Tropics and Subtropics, 112, 29-36.

Sarkar, A. (2011). Socio-economic implications of depleting groundwater resource in Punjab: A comparative analysis of different irrigation systems. Economic and Political Weekly, 46(7), 59-66.

Schaner, N., et al. (2012). The contribution of glacier melt to streamflow. Environmental Research Letters, 7, 034029. http:// stacks.iop.org/1748-9326/7/i=3/a=034029?key=crossref. 1d60a5b89febe92ea66fea367de538be. 22 Accessed Sept. 2013.

Scott, C. A., Meza, F. J., Varady, R. G., Tiessen, H., McEvoy, J., Garfin, G. M., et al. (2013). Water security and adaptive management in the arid Americas. Annals of the Association of American Geographers, 103(2), 280-289.

Scott, C. A., Crootof, A., Thapa, B., \& Shrestha, R. K. (2016). Water-food-energy nexus: Challenges and opportunities. In L. Bharati, B. R. Sharma, \& V. Smakhtin (Eds.), The Ganges River Basin: Status and challenges in water, environment and livelihoods. London: Routledge.

Sehar, S., Naz, I., Ali, M. I., \& Ahmed, S. (2011). Monitoring of physico-chemical and microbiological analysis of underground water samples of district Kallar Syedan, Rawalpindi, Pakistan. Research Journal of Chemical Sciences, 1, 24-30.

Senanayake, N., \& Mukherji, A. (2014). Irrigating with arsenic contaminated groundwater in West Bengal and Bangladesh: A review of interventions for mitigating adverse health and crop outcomes. Agricultural Water Management, 135(2014), 90-99.

Shah, R. D. T., \& Shah, D. N. (2013). Evaluation of benthic macroinvertebrate assemblage for disturbance zonation in urban rivers using multivariate analysis: Implications for river management. Journal of Earth System Science, 122(4), 1125-1139.

Shah, T. (2007). Crop per drop of diesel: Energy squeeze on India's small holder agriculture. Economic and Political Weekly, 42(39), 4002-4009.

Shah, T. (2009). Climate change and groundwater: India's opportunities for mitigation and adaptation. Environmental Research Letters, 4.

Shah, T., \& Giordano, M. (2013). Himalayan water security: A South Asian perspective. Asia Policy, 16(1), 26-31.

Shah, T., Singh, O. P., \& Mukherji, A. (2006). Some aspects of South Asia's groundwater irrigation economy: analyses from a survey in India, Pakistan, Nepal Terai and Bangladesh. Hydrogeology Journal, 14(3), 286-309.

Sharda, V. (2005). Integrated watershed management: managing valleys and hills in the Himalayas. Watershed Management Challenges, 61.

Sharif, M., et al. (2013). Trends in timing and magnitude of flow in the Upper Indus Basin. Hydrology and Earth System Sciences, 17(4), 1503-1516. http://www.hydrol-earth-syst-sci.net/17/1503/2013/. Accessed 22 Jan. 2014.

Sharma, B., Nepal, S., Gyawali, D., Pokharel, G. S., Wahid, S. M., Mukherji, A., et al. (2016). Springs, storage towers, and water conservation in the midhills of Nepal. Nepal Water Conservation Foundation and International Center for Mountain Development. ICIMOD Working Paper 2016/3. Kathmandu: Nepal.

Shea, J. M., Immerzeel, W. W., Wagnon, P., Vincent, C., \& Bajracharya, S. (2015a). Modelling glacier change in the Everest region, Nepal Himalaya. The Cryosphere, 9, 1105-1128.

Shea, J. M., Wagnon, P., Immerzeel, W. W., Biron, R., Brun, F., \& Pellicciotti, F. (2015b). A comparative high-altitude meteorological analysis from three catchments in the Nepalese Himalaya. International Journal of Water Resources Development, 31(2), 174-200.
Shen, M., Piao, S., Jeong, S.-J., Zhou, L., Zeng, Z., Ciais, P., et al. (2015). Evaporative cooling over the Tibetan Plateau induced by vegetation growth. Proceedings of the National Academy of Sciences, 112(30), 9299-9304.

Singh, L. J., \& Choudhury, D. (2015). Fallow-management practices among the Tangkhuls of Manipur: Safeguarding provision and regulatory services from shifting-cultivation fallows. In F. C. Malcolm (Ed.) Shifting cultivation and environmental change: Indigenous people, agriculture and forest conservation. Routledge (pp. 449-467), New York.

Shi, X., Zhang, F., Lu, X., Wang, Z., Gong, T., Wang, G., et al. (2018). Spatiotemporal variations of suspended sediment transport in the upstream and midstream of the Yarlung Tsangpo River (the upper Brahmaputra), China. Earth Surface Processes and Landforms, 43 (2), 432-443. https://doi.org/10.1002/esp.4258.

Shrestha, R., Desai, J., Mukherji, A., Dhakal, M., Kulkarni, H. \& Acharya, S. (2017). Application of eight-step methodology for reviving springs and improving springshed management in the Mid-hills of Nepal, Research Highlight, ICIMOD. http://lib.icimod. org/record/32564/files/icimodWLE017.pdf.

Shrestha, A. B., Agrawal, N. K., Alfthan, B., Bajracharya, S. R., Maréchal, J., \& van Oort, B. (Eds.). (2015a). The Himalayan climate and water Atlas: Impact of climate change on water resources in five of Asia's major river basins. GRID-Arendal and CICERO: ICIMOD.

Shrestha, M., Koike, T., Hirabayashi, Y., Xue, Y., Wang, L., Rasul, G., et al. (2015b). Integrated simulation of snow and glacier melt in water and energy balance-based, distributed hydrological modeling framework at Hunza River Basin of Pakistan Karakoram region. Journal of Geophysical Research: Atmospheres, 120(10), 4889 4919.

Shrestha, O. M., Koirala, A., Hanisch, J., Busch, K., Kerntke, M., \& Jäger, S. (1999). A geo-environmental map for the sustainable development of the Kathmandu Valley, Nepal. GeoJournal, 49(2), $165-172$.

Shrestha, P., Lord, A., Mukherji, A., Shrestha, R. K., Yadav, L. \& Rai, N. (2016). Benefit sharing and sustainable hydropower: Lessons from Nepal, ICIMOD Research Report, 2016/2. International Centre for Integrated Mountain Development, Kathmandu, Nepal.

Shrestha, R. K., Ahlers, R., Bakker, M., \& Gupta, J. (2012). Institutional dysfunction and challenges in flood control: A case study of the Kosi Flood 2008. Economic and Political Weekly, 2, $45-53$.

Siddiqi, A., \& Wescoat, J. L. (2013). Energy use in large-scale irrigated agriculture in the Punjab province of Pakistan. Water International, 38(5), 571-586.

Singh, A. K., \& Pande, R. K. (1989). Changes in spring activity: Experiences of Kumaun Himalaya, India. Environmentalist, 9(1), $25-29$.

Singh, P., \& Jain, S. K. (2002). Snow and glacier melt in the Satluj River at Bhakra Dam in the western Himalayan region. Hydrological Sciences Journal, 47(1), 93-106. http://www.tandfonline.com/ doi/abs/10.1080/02626660209492910. Accessed 2 Oct. 2013.

Singh, R. A., \& Gupta, R. C. (2002). Traditional land and water management systems of North-East Hill regions. Indian Journal of Traditional Knowledge, 1(1), 32-39.

Singh, S. K. (1990). Evaluating Large Dams in India. Economic and Political Weekly, 25, 561-574.

Sinha, R. (2009). The Great avulsion of Kosi on 18 August 2008. Current Science, 97(3), 429-433.

Sinha, R., Priyanka, S., Jain, V., \& Mukul, M. (2014). Avulsion threshold and planform dynamics of the Kosi river in north Bihar 
(India) and Nepal: A GIS framework. Geomorphology, 216, 157170.

Soncini, A., et al. (2015). Future hydrological regimes in the Upper Indus Basin: A case study from a high-altitude glacierized catchment. Journal of Hydrometeorology, 16(1), 306-326. http:// journals.ametsoc.org/doi/abs/10.1175/JHM-D-14-0043.1.

Tahir, A. A., Chevallier, P., Arnaud, Y., et al. (2015). Snow cover trend and hydrological characteristics of the Astore River basin (Western Himalayas) and its comparison to the Hunza basin (Karakoram region). Science of the Total Environment, 505, 748-761.

Tahmiscioğlu, M. S., \& Anul, N. (2007). Positive and negative impacts of dams on the environment. Ankara: International Congress on River Basin Management.

Tambe, S., Arrawatia, M., Kumar, R., Bharti, H., \& Shrestha, P. (2009). Conceptualizing strategies to enhance rural water security in Sikkim, Eastern Himalaya, India. Integrated Water Resource Management, 1 .

Tambe, S., Kharel, G., Arrawatia, M. L., et al. (2012). Reviving dying springs: Climate change adaptation experiments from the Sikkim Himalaya. Mountain Research and Development, 32(1), 62-72.

Tarafdar, S. (2013). Understanding the dynamics of high and low spring flow: A key to managing the water resources in a small urbanized hillslope of Lesser Himalaya, India. Environmental earth sciences, 70(5), 2107-2114.

Thapa, B., Scott, C. A., Wester, P., \& Varady, R. (2016). Towards characterizing the adaptive capacity of farmer-managed irrigation systems: Learnings from Nepal. Current Opinion in Environmental Sustainability, 21, 37-44. https://doi.org/10.1016/j.cosust.2016.10. 005.

Tiwari, P. C., \& Joshi, B. (2014). Environmental changes and their impact on rural water, food, livelihood, and health security in Kumaon Himalaya. International Journal of Urban and Regional Studies on Contemporary India, 1, 1-12.

Trivedi, R. C., (2010). Water quality of the Ganga rive-An overview. Aquatic Ecosystem Health \& Management.

Udas, P. B., \& Zwarteveen, Margreet. (2010). Can water professionals meet gender goals? A case study of the Department of Irrigation in Nepal. Gender and Development, 18(1), 87-97.

UN-Water. (2013). Water security and the global water agenda: a $U N$-water analytical brief. Hamilton, Ontario: United Nations University.

van Steenbergen, F. (1997). Understanding the sociology of spate irrigation: Cases from Balochistan. Journal of Arid Environments, 35, 349-365.

Vaidya, R. (2012). Water and hydropower in the green economy and sustainable development of the Hindu Kush-Himalayan Region. Hydro Nepal: Journal of Water, Energy and Environment, 10.
Valdiya, K., \& Bartarya, S. (1989). Diminishing discharges of mountain springs in a part of Kumaun Himalaya. Current Science. Bangalore, 58(8), 417-426.

Vashisht, A., \& Bam, B. (2013). Formulating the spring discharge-function for the recession period by analyzing its recession curve: A case study of the Ranichauri spring (India). Journal of Earth System Science, 122(5), 1313-1323.

Vashisht, A., \& Sharma, H. (2007). Study on hydrological behaviour of a natural spring. Current Science, 93(6), 837-839.

Vincent, L. (1995). Hill irrigation. Water and development in mountain agriculture. London: Intermediate Technology Publications.

Wang, S., Fu, B., Piao, S., et al. (2016). Reduced sediment transport in the Yellow River due to anthropogenic changes. Nature Geoscience, 9(1), 38.

Wang, Z. Y., Li, Y., He, Y. (2007). Sediment budget of the Yangtze River. Water Resources Research, 43(4).

Wasson, R. J. A. (2003). sediment budget for the Ganga-Brahmaputra catchment. Current Science, 84(8), 1041-1047.

WHO. (2006). Guidelines for the safe use of wastewater in agriculture. Geneva, Switzerland: World Health Organisation.

Xu, X., Lin, H., \& Fu, Z. (2004). Probe into the method of regional ecological risk assessment - a case study of wetland in the Yellow River Delta in China. Journal of Environmental Management, 70 (3), 253-262.

Yang, S. L., Zhang, J., Xu, X. J. (2007). Influence of the Three Gorges Dam on downstream delivery of sediment and its environmental implications. Yangtze River. Geophysical Research Letters, 34(10).

Yang, S. L., Milliman, J. D., Li, P., et al. (2011). 50,000 dams later: Erosion of the Yangtze River and its delta. Global and Planetary Change, 75(1), 14-20.

Yang, Y. E., Brown, C., Winston, Y., Wescoat, J., \& Ringler, C. (2014). Water governance and adaptation to climate change in the Indus River Basin. Journal of Hydrology, 519, 2527-2537.

Yoder, R. (1986). The performance of farmer-managed irrigation systems in the hills of Nepal. Unpublished Ph.D. dissertation, Cornell University, Ithaca, NY.

Zeng, C., Zhang, F., Lu, X., Wang, G. X., \& Gong, T. L. (2018). Improving sediment load estimations: The case of the Yarlung Zangbo River (the upper Brahmaputra, Tibet Plateau). CATENA, 160, 201-211.

Zhang, L., Su, F., Yang, D., et al. (2013). Discharge regime and simulation for the upstream of major rivers over Tibetan Plateau. Journal of Geophysical Research: Atmospheres, 118(15), 85008518. 
Open Access This chapter is licensed under the terms of the Creative Commons Attribution 4.0 International License (http:// creativecommons.org/licenses/by/4.0/), which permits use, sharing, adaptation, distribution and reproduction in any medium or format, as long as you give appropriate credit to the original author(s) and the source, provide a link to the Creative Commons license and indicate if changes were made.
The images or other third party material in this chapter are included in the chapter's Creative Commons license, unless indicated otherwise in a credit line to the material. If material is not included in the chapter's Creative Commons license and your intended use is not permitted by statutory regulation or exceeds the permitted use, you will need to obtain permission directly from the copyright holder. 